\title{
Dyspepsia and campylobacter associated gastritis : clinical and pathological studies
}

Citation for published version (APA):

Loffeld, R. J. L. F. (1989). Dyspepsia and campylobacter associated gastritis : clinical and pathological studies. [Doctoral Thesis, Maastricht University]. Rijksuniversiteit Limburg. https://doi.org/10.26481/dis.19891214rl

Document status and date:

Published: 01/01/1989

DOI:

10.26481/dis.19891214rl

Document Version:

Publisher's PDF, also known as Version of record

\section{Please check the document version of this publication:}

- A submitted manuscript is the version of the article upon submission and before peer-review. There can be important differences between the submitted version and the official published version of record.

People interested in the research are advised to contact the author for the final version of the publication, or visit the DOI to the publisher's website.

- The final author version and the galley proof are versions of the publication after peer review.

- The final published version features the final layout of the paper including the volume, issue and page numbers.

Link to publication

\footnotetext{
General rights rights.

- You may freely distribute the URL identifying the publication in the public portal. please follow below link for the End User Agreement:

www.umlib.nl/taverne-license

Take down policy

If you believe that this document breaches copyright please contact us at:

repository@maastrichtuniversity.nl

providing details and we will investigate your claim.
}

Copyright and moral rights for the publications made accessible in the public portal are retained by the authors and/or other copyright owners and it is a condition of accessing publications that users recognise and abide by the legal requirements associated with these

- Users may download and print one copy of any publication from the public portal for the purpose of private study or research.

- You may not further distribute the material or use it for any profit-making activity or commercial gain

If the publication is distributed under the terms of Article $25 \mathrm{fa}$ of the Dutch Copyright Act, indicated by the "Taverne" license above, 
DYSPEPSIA AND CAMPYLOBACTER ASSOCIATED GASTRITIS

CLINICAL AND PATHOLOGICAL STUDIES

R.J.I. . . LOFFELD 


\title{
DYSPEPSIA AND CAMPYLOBACTER ASSOCIATED GASTRITIS clinical and pathological studies \\ Proefschrift
}

ter verkrijging van de graad van doctor aan de Rijksuniversiteit Limburg te Mastricht, op gezag van de Rector Magnificus, Prof. DI. F.I.M. Bonke, volgens het besluit van het College van Dekanen, in het openbaar te verdedigen op donderdag, 14 december 1989 om 14.00 uur

door

\author{
Rudolf Johannes Louis Franciscus Loffeld \\ geboren te Heerlen in 1953
}


Promotores: Prof. Dr. J.A. Flendrig

Prof. Dr. J.W. Arends

Beoordelingscommissie: Prof. Dr. C.P.A. van Boven, voorzitter Prof. Dr. P.J. Brombacher

Prof. Dr. R.H. Kuijten

Prof. Dr. P.B. Soeters

Prof. Dr. G.N.J. Tytgat

Druk: Datawyse Maastricht

Dit proefschrift is mede tot stand gekomen dankzij ondersteuning van Gist-Brocades, Hoechst, Sarva syntex en het scholten-Cordes fonds. 
Aan zij die mij dierbaar zijn. 
Chapter $1:$ Scope and outline of investigations.............

Chapter 2 : Review of the literature...................

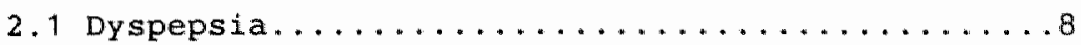

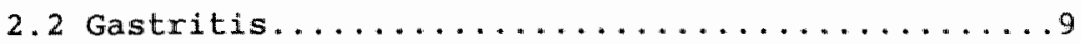

2.3 Historical summary...................... 10

2. 4 Microbiological characteristics............... 11

2.5 Histological characteristics................ 13

2.6 Campylobacter associated gastritis............ 14

Chapter 3: Campylobacter associated gastritis in patients

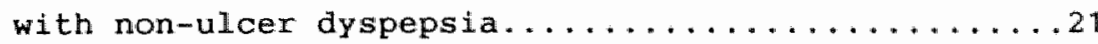

Chapter 4: Detection of Campylobacter pylori in gastric biopsy specimens: comparison of culture, modified Giemsa stain, and immunohistochemistry.......31

Chapter 5: Detection of anti Campylobacter pylori antibodies for the assessment of Campylobacter associated gastritis in patients with non-ulcer dyspepsia................................ 45

Chapter 6: The prevalence of anti Campylobacter pylori antibodies in patients and healthy blood donors. . . . . . . . . . . . . . . . 61

Chapter 7: Retrospective study of Campylobacter-like organisms in patients undergoing partial

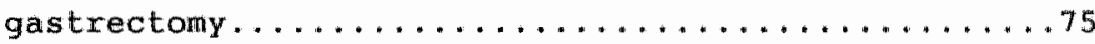

Chapter 8: Campylobacter associated gastritis in patients with non-ulcer dyspepsia: a placebo controlled double blind trial with colloidal bismuth

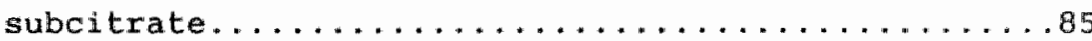

Chapter 9: Epilogue.............................. 101

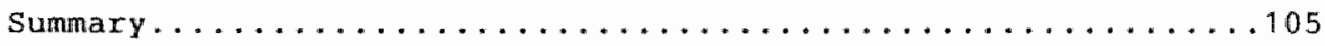
Nederlandstalige samenvatting........................11 Dankwoord. . . . . . . . . . . . . . . . . . . . . . . . 117

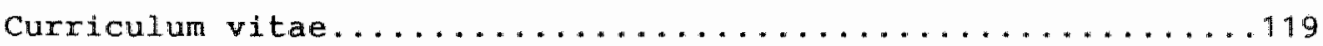




\section{SCOPE AND OUTLINE OF INVESTIGATIONS}

Patients with so-called non-ulcer dyspepsia generally pose a great problem to the clinician. Non-ulcer dyspepsia is defined as presence of upper abdominal complaints such as epigastric pain, nausea, heartburn, burping, bloating and others with absence of macroscopic pathology in the upper gastrointestinal tract at endoscopy and absence of symptomatic gallbladder disease. "The condition is very common and notoriously difficult to manage. among others because of its obscure aetiology. Therefore effective treatment is not available. As a consequence non-ulcer dyspepsia is a frustration to both the unrelieved patient and the helpless doctor.

Gastritis has been considered to be related with non-ulcer dyspepsia, the exact relation, however, is not clear. Inflammation of the gastric mucosa can be found in symptomatic as well as in asymptomatic individuals, and in many studies no or only weak correlations were demonstrated between the presence of gastritis and non-ulcer dyspepsia.

In the past few years new impulses were given to gastritis research due to the description of a new microorganism, Campylobacter pylori. There is evidence that Campylobacter pylori is of pathogenetic importance for type B (antral) gastritis.

The emergence of so-called Campylobacter associated gastritis now challenges clinicians to again attack the problem of non-ulcer dyspepsia, since it is concelwable that this type of gastritis might show a more stringent relation to this condition than gastritis in general.

Against this background several studies were performed concerning the diagnosis, pathogenesis, and treatment of Campylobacter associated gastritis, mainly, but not exclusively, focussed on the clinical significance of this type of gastritis for patients with non-ulcer dyspepsia.

The following chapter of this thesis provides a review on 
the relevant 1 iterature of gastritis and Campylobacter pylori.

To be able to address the relation between Campylobacter assoclated gastris and non-ulcer dyspepsia adequately, reliable and sensitive diagnostic techniques for detection of the microorgandsm in sections of gastric mucosa had to be developed. In chapter 3 a brief report is given on the use of a simple modiffed Giemsa stain. Also the prevalence of Campylobacter associated gastritis in patients with non-ulcer dyspepsia is addressed explditly in this chapter. Chapter 4 describes the results of a more specific immunohistochemical procedure employing a polyclonal anti Campylobacter pylori antiserum for the histological diagnosis of the microorganism in comparison with other detection methods. Microbiological and histological diagnosis, however, requires endoscopy, which may be straining for a patient, involves considerable time as well as costs, and hence does not allow large scale epidemiological studies on the occurrence of Campylobacter associated gastritis in different population groups and dyspeptic patients. We, therefore, developed an ELISA for serological diagnosis of Campylobacter pylori infection. In chapter 5 a report is given on its correlation with microbiological and histological detection methods and chapter 6 describes its value in a large scale study on a population of healthy blood donors and patients. The study in chapter 7 approaches a pathogenetic aspect of Campylobacter pylori and antral gastritis exploring the fate of the microorgaHini in patients hawing whergone antrectomi because of peptic ulcer disease, a condition also known to be associated with Campylobacter pylori. The question, whether anti Campylobacter pylori therapy is effective in treatment of Campylobacter associated gastritis in patients with non-ulcer dyspepsia was investigated in a randomised placebo controlled intervention trial with colloidal bismuth subcitrate, the results of which are shown in chapter 8 .

In the fimal chapter the results of the investigations are discussed especially in relation to the significance of Campylobacter associated gastritis for non-ulcer dyspepsia patients. In addition some general contemplations on the subject and proposals for further research are presented. 


\section{REVIEW OF THE LITERATURE}

Part of this chapter is published entitled: "Dyspepsia zonder ulcus ("non-ulcer dyspepsia") en met Campylobacter samenhangende gastritis" in: het Nederlands 'Tujdschrift voor Geneeskunde $1989 ; 133: 1489-93$. 


\subsection{DYSTRPSA}

Dyspepsia is a clinical syndrome which is hard to define. various upper abdominal complaints have been included in the synarome [1, 2]. As a result more than 20 definitions have been put forward. The one mostly applied in daily practice is the combination of epigastric pain, bloating, indigestion, nausea, burping, and heartburn [3].

Dyspepsia may be caused by a great number of pathologic processes and diseases in the alimentary tract and related organs, as well as in other internal organs and may also occur in certain systemic diseases [4]. The majority of conditions causing dyspepsia, however, are confined to the upper gastrointestinal tract.

Originally it was thought that the clinical picture would be sufficient to diagnose the nature of dyspepsia [5], but this contention was recently rejected [6]. Therefore, additional invasive and non-invasive diagnostic procedures are necessary in the work-up of dyspeptic patients $[7,8]$.

When after investigations like upper gastrointestinal endoscopy and ultrasound studies of liver, pancreas, and gallbladder, in a number of cases peptic ulceration, gastric and oesophageal carcinoma, duodenitis, refluxoesophagitis, symptomatic gallbladder disease and other macroscopic visible lesions in oesophagus, stomach, and duodenum cannot be detected [7], dyspeptic patients by definition suffer from so-called non-ulcer dyspepsia. From the abowe list of conditions to be excluded in non-ulcer dyspepsia it is obvious that in fact the designation is incorrect. A better designation would be "essential dyspepsia" or "idiopathic dyspepsia". The term non-ulcer dyspepsia, however, is widely used and accepted in the literature.

Non-ulcer dyspepsia is a very common clinical problem. Its prevalence is probably twice as high as the prevalence of peptic ulcer disease [7,9]. However, because of absence of serious illness or complaints many patients refrain from seeking medical advise $[10,11]$. The prognosis generally is good, but according to some authors complete cure is not always possible $[3,12,13]$. The exact nature of non-ulcer dyspepsia is enigmatic. Gastritis and motility disorders have been held responsible for the syndrome. 
There is an ongoing debate as to whether gastritis is related to non-ulcer dyspepsia. Gastritis is particularly common in Scandinavian countries, where population studies showed that signs of gastritis often are present in the stomach of symptomatic as well as asymptomatic individuals $[14,15]$. Healthy asymptom matic individuals appear to show signs of gastritis in $20 \%$ to approximately 50 of cases with rising age. Some workers, therefore argue that gastritis is an aging phenomenon of the stomach without clinical significance [16,17]. Others, however, maintain that gastritis, especially when longstanding, is responsible for non-ulcer dyspepsia $[18,19]$, and that the condition cannot be considered to be of no clinical significance given the fact that patients have a $40 \%$ higher chance of developing a peptic ulcer as compared to individuals who show normal antral mucosa [20].

There was not much progress in gastritis research until recently when Marshall and Warren described a microorganism in the stomach which presence is strongly correlated with type $B$ gastritis.

\subsection{GASTRITIS}

So far, chronic gastritis has been classified into two types. One (type A), the autoimmune gastritis which leads to pernicious anemia, mainly affects body mucosa, it is associated with hypochlorhydria, the presence in the serum of anti parietal cell antibodies [21] and autoimmune conditions of other organs. This type of chronic gastritis is usually asymptomatic, and because basically only parietal cells are affected the antrum of the stomach is spared.

The other (type B gastritis) is much more common. It is found predominantly in the antrum and is associated with peptic ulceration. The condition mainly affects the mucus secreting antral type gastric epithelium and often spares the acid secreting part of the stomach. Both exogenous and endogenous irritants such as hot drinks, spices, and bile reflux, are suggested causes of type B gastritis [22]. Type B gastritis histopathologicaliy may show an acute (neutrophilic) as well as a chronic 
(mononvelear) component, and does not demonstrate specific features. The acute active inflamation greatly varies in severity from patient to patient, sometimes showing only rare foci of epithelial infiltration, while in other instances the active component is widespread. In the latter cases both antral and Lundal areas may be involved in the process [23].

A thixd type (designated as AB) has been distinguished [24]. It exhlbits patchy gastritis in antral and body mucosa and is associated with a higher incidence of gastric ulcer, dysplasia and gastric carcinoma.

since 1983 a growing number of reports has confirmed Marshall and Warren's original observation [25] on the association of a Gram negative microorganism, presently known as Campylobacter pylori, and type B gastritis. Campylobacter associated gastritis is present in $95 \%$ of duodenal ulcer patients $[25,26,27,28,29]$ and in $70-80$ of gastric ulcer patients $[25,26,27,28,30 \mathbb{}$. Like gastritis [31], Campylobacter pylori is also found among the healthy (asymptomatic) population. Its prevalence increases with age and approaches $50 \%$ in the elderly. Campylobacter associated gastritis can be found in $25 \%$ of the healthy volunteers $[32,33]$. The bacterium, however, has not been detected in type $\mathrm{A}$ gastritis [34].

\subsection{HISTORICAL SUMMARY ON GASTRIC SPIRAL ORGANISMS}

observations of spiral organisms in human gastric mucosa

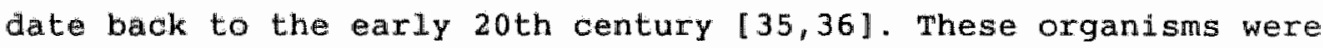
regarded as curlosities without demonstrated relevance to disease and therefore not taken seriously, although krienitz [35] postulated that the microorganisms could be of relevance with regard to the etiology of gastric carcinoma. In 1939 Doenges observed splrochetes in 43\% of human stomachs at autopsy [37]. Freedburg and Barron [38】 demonstrated curved bacilli in gastrectomy specimens, usually associated with benign or malignant gastric ulcers, but did not comment on the clinical importance of their observation. In an attempt to clarify controversies in earlier work palmer examined 1.000 suction biopsy specimens of gastric mucosa [39], but failed to detect spiral bacteria. This author, 
however, mainly studied biopsy specimens contalning body type mucosa and did not make use of silver staining methods for detection of spiral bacteria. In 1975 steer and collin-Jones found bacteria in gastric biopsy specimens from patients with a gastric ulcer [40]. They postulated that the organisms seen were pseudomonas aeruginosa contaminating the endoscope and the biopsy material. In 1983 Marshall and Warren noticed spiral bacteria in gastric mucosa from patients with gastritis and peptic ulcer 125 , 41], and were the first to successfully culture the observed microorganisms. Because of the similarities to Campylobacters they initially designated the bacterium Campylobacter pyloridis. More recently the name was modified to Campylobacter pylori [42] to correct a nomenclatural error.

\subsection{MICROBIOLOGICAL CHARACTERISTICS OF CAMPYLOBACIER PYLORI}

Campylobacter pylori is a Gram negative bacterium, usually showing an S-shape but sometimes demonstrating U-shaped, circular, irregular, rod shaped or coccoid configurations. The bacillus is 3 micrometer in length and 0.5 micrometer in width. In histological sections the bacteria appear smaller and more curved as compared to cultured bacteria, which assume coccold forms. Perhaps this indicates that ideal conditions for growth of the microorganism have not yet been obtained in vitro conditions [43]. The bacterium has a smooth outer coat and possesses four unipolar flagellae, which are sheathed with terminal bulbs similar to those seen in Vibrios [44].

The distribution of organisms within the stomach may be patchy or focal and the number of organisms seen in several biopsy specimens from the same patient may vary widely.

The microorganism can be cultured on specific culture media but also on blood agar containing 6\% sheep blood [44]. Microaerophilic conditions $\left(5-20 \% \mathrm{O}_{2}, 5-20 \% \mathrm{CO}_{2}\right)$ and humid atmosphere are very important for growth. Optimal growth can be seen after three to four days, which accounted for the circumstance that Marshall could culture his first strain because, due to easter holidays a medium was incubated longer than usual [25]. 
The cultured microorganisms appear as small transparent colonies with a dameter of about one milimeter $[25,28,46,47]$. There are numerous conditions and circumstances that can influence culture adversely leading to false negative culture results [46]. Campylobacter pylori is susceptible for shrinkage and therefore blopsy specimens should be transported in a humid environment. The use of anaesthetic gels and simethicon during endoscopy should be omitted. Bouln's fixative, formaldehyde or glutaraldehyde will kill the bacterium. Also recent use of antibioties or bismuth preparations provides false negative cultures, since these agents are bactericidal against campylobacter pylori. Culture can be negative in case of low bacterial load, and finally heavy bacterial overgrowth may occur on the culture medium due to bacterial contamination of gastric biopsies from mouth and throat [46].

Campylobacter pylori produces a couple of enzymes like axidase, catalase, alkaline phosphatase and urease [32]. The microorganism does not reduce nitrate or hydrolyze hippurate. The urease production has been adapted for use as a rapid diagnostic test for the organisms presence in gastric biopsy specimens. Gastric urease was described as early as 1924 [48]. The clinical importance, however, was recognized only recently.

Campylobacter pylori probably belongs to the genus Campylobacter. Although it resembles bacteria of this genus, Campylobacter pylori has also been called a "Campylobacter-1ike organism" because of divergent features. The bacillus has a smooth surface in contrast to the wrinkled surface of campylobacter jejuni. The bacterium usually shows four to six unipolar sheathed flagellae [44] in stead of only one unsheathed flagella. Additional differences include fatty acid composition [49], respiratory quinones [50,51], protein profiles [52], and the urease and catalase activity [531. In a recently reported comparison of 165 rRNA sequences, it was concluded that Campylobacter pylori is more closely related to wolinella succiniogenes and to a sulfide dependent marine bacterium, Thiovulum, than to other Campylobacter species [54]. On the other hand, Campylobacter pylori resembles other Campylobacters in many aspects. These include a similar DNA base composition of guanine 
and cytosine [44], common antigenic characteristics [55], shape, culture conditions, and the inability of metabolizing sugars. Although the exact taxonomic status of the microorganism thus still is subject to uncertainty, the designation Campylobacter pylori is currently official [42].

Campylobacter pylori is sensitive to a wide range of antibiotics in vitro, like penicillin, erythromycin, tetracycline, tinidazole, metronidazole, and gentamicin, but not to trimethoprim, nalidixic acid, and vancomycin [46,56].

Campylobacter pylori is also susceptible to the anti-ulcer medication colloidal bismuth subcitrate and bismuth salicylate. It is insensitive to cimetidine, carbenoxolone, sucralfate, and antacids. Results of in vivo susceptibility differ from in vitro studies. In vivo the bacterium is not susceptible to doxycycline or erythromycin [57], and resistance to quinolones has been reported. In contrast studies with bismuth and/or amoxycilin show good in vivo results $[57,58,59]$.

The route of transmission of Campylobacter pylori is not known. An animal reservoir for the microorganism is not known although recent studies suggest the presence of Campylobacterlike organisms in the stomach of baboons, pigs, and ferrets $[60,61]$.

\subsection{HISTOLOGICAL CHARACTERISTICS}

The morphological appearance of Campylobacter pylori is sufficiently distinctive to allow its identification in histological sections. Campylobacter pylori has selected a very specific ecological niche. The organism colonizes gastric antral. and fundal epithelium and gastric metaplastic epithellum in the duodenal bulb exclusively [26]. The organism cannot be detected at other sites such as mouth cavity, small intestine, colon, rectum, blood, and genitourinary tract. In areas with intestinal metaplasia in the stomach the bacillus is absent, a sharp demarcation between absence and presence of Campylobacter pylori is seen on the border of intestinal metaplasia and gastric epithelium. Numerous bacteria can be seen in the mucus layer. Campylobacter pylori is susceptible to acid. Therefore, the 
bactexium cannot be detected in a peptic ulcer crater [62]. The reason for wurvival in the stomach is the ability of the bacterium to produce urease resulting in a release of ammonia with hydrogen ion back diffusion which results in an increase of gastric pH just below the mucus layer. The organism can also be observed lying closely attached to the mucosal cells. An "adherence pedestal" exists between the cell and the bacterium which is morphologically parallel to that seen in enteropathogenic Escherichia coli [53].

The reason for the specific affinity with gastric epithelium is not known. It is hypothesized that special growth factors or nutrients such as urea and hemin, are derived from the gastric epithelium [62]. This is supported by the observation that bacterla are most numerous over intercellular junctions, the site at which exudate of serum proteins occurs during inflamation [63].

\subsection{CAMPXLOBACTER ASSOCIATED GASTRITIS}

In view of the close association of Campylobacter pylori with type B (antral) gastritis it seems likely that the microorganism is of pathogenetic importance. Yet the question whether the bacterium acts as a primary or secondary pathogen or is to be regarded as a commensal is still not definitively resolved. Scepticists think that its presence merely represents an epiphenomenon. However, there is a growing body of ewidence linking Campylobacter pylori in a specific and causal way to type B gastritis. The evidence includes histological observations $[25,26,27]$, data from human $[64,65]$ and animal models $[60,66]$, considerations about possible pathogenetic mechanisms $[67,68,69]$ and the observed effect of therapeutic eradication or suppression of the microorganism on the underlying mucosal inflammation $[57,58,59]$.

Before pathogenicity of a microorganism can be established the three postulates of Koch must be fulfilled. The first and second postulate (the bacterium should be present in all cases of disease and should be maintained in culture for several generations outside the host) have been fulfilled. The third postulate 
that the organism should reproduce the disease when inoculated into a susceptible host, is much more difficult to prove, especially since an effective animal model for campylobacter associated gastritis is not yet awailable. Two studies reported on some promising animal experiments, one using the rhesus monkey [41], the other gnotobiotic piglets [66].

Two case reports tried to answer the question of pathogenecity by means of a human experiment. Marshall ingested a culture of Campylobacter pylori which resulted in a mild gastrointestinal disturbance seven days later [64]. "This experiment of self inoculation showed that Campylobacter pylori was able to colonise a previously normal mucosa and also to cause dyspeptic complaints. In addition histological examination revealed a Campylobacter associated gastritis. Another volunteer [65] reacted likewise. Both volunteers were shown to have histologically normal gastric mucosa before inoculation. The clinical picture found in both volunteers fitted well into the description of an epidemic of hypochlorhydria in the past $[70,71]$, which so far could not be explained. Twenty out of 43 healthy individuals participating in gastric secretion studies developed a transient illness with nausea, vomiting and abdominal pain. Mean basal and peak acid outputs were diminished. All individuals showed an active antral gastritis on histological examination. Acid secretion returned to normal in the majority of the persons after a couple of months. An infectious etiology was suspected but no candidate agent was identified. Retrospective serological. studies in sera of these patients revealed an antibody response against Campylobacter pylori [72].

Antibody responses can be detected, systemically as well as locally $[67,73,74]$. The titre of these antibodies possibly correlates with the severity of gastritis [67]. Antibody coating of mucosal organisms can be demonstrated by immunohistochemical techniques [75]. In vitro studies showed that ant1 Campylobacter pylori immunoglobulines are being produced by plasma cells in the lamina propria [76].

The exact pathophysiological mechanisms underlying Campylobacter associated gastritis are not known. In the literature several hypotheses have been suggested. In ultrastructural 
studies tisue invasion has been described [49,50]. In the mucus cells there is distuption of mucus secretory droplets and abundant phagolysosomes and disruption of intercellular tight junctions can be noticed. A promising hypothesis is the action of bacterial urease on urea. A sodium ion gradient from the gastric Iumen to the epithelial surface is present and maintenance of this gradient by a sodium/potassium-ATP-ase-pump system is the driving force for the passage of hydrogen ions into the lumen, at the same time preventing back diffusion of hydrogen ions. Campylobacter pylori tends to assemble at gastric epithelial Intercellular junctions possibly because urea diffuses across the mucosa by the paracellular pathway. The rapid hydrolysis of urea by Campylobacter pylori at this site would produce a transmucosal urea gradient, inducing a net flow of urea to the luminal side of the mucosa. Continuing urea hydrolysis subsequently would lead to an increase in mucosal surface pH and the generation of a transmucous ammonium gradient. These changes in the mucosal environment prevent the normal passage of hydrogen ions from the gastric glands to the gastric lumen and permit back diffusion. This back diffusion of hydrogen ions would possibly induce inflammatory changes [68]. However, a direct toxic effect of ammonia on gastric mucosa also is plausible [68]. Campylobacter pylori elaborates an extracellular protease which destroys the integrity of the protective mucus layer by causing degradation of its mucin constituent [69]. Cytotoxic activity of Campylobacter pylori also is suggested [77], but these data are rather preiliminary.

\section{REFERENCES}

1 de Dombal FT. Analysis of foregut symptoms. In: JH Barron, FC Moodey ed Butterworth" s International Medical Reviews. Gastroenterology" I Foregut London and Boston Butterworth"s $1981 ; 49-66$.

2 Talley NJ, Piper DW. The association between non-ulcer dyspepsia and other gastrointestinal disorders. Scand $\mathrm{J}$ Gastroenterology 1985;20:896-900.

3 Heatley RV, Rathbone BJ. Dyspepsia: a dilemma for doctors? Lancet $1987 ; 1: 779-81$.

4 Krag E. Other causes of dyspepsia scand J Gastroenterology $1982 ; 17$ (supplement) $: 32-4$. 
5 Moymihan BGA. On duodenal ulcer: with notes of 52 operations. Lancet $1905 ; 1: 340-6$.

6 Horrocks JC, de Dombal PT. Clinical presentation of patients with dyspepsia. Gut 1978;19:19-26.

7 Anonywous. Non-ulcer dyspepsia. Lancet $1986 ; 1: 1306-7$.

8 Tylistrom $J$, Adami no, Agenas $I$ et al. The clinical presentation of gastritis II: aspects of current therapy and drug consumption. Scand J Gastroenterology 1984;19:755-60,

9 williams JG. Non-ulcer dyspepsia. I Roy Nav Med Serv $1986 ; 72: 5-8$.

10 Doll $\mathbb{R}_{*}$ Avery-Jones $\mathbf{F}$, Bukatsch $\mathrm{MM}$. MRC special report series 1951. Number 276 London: HMSO.

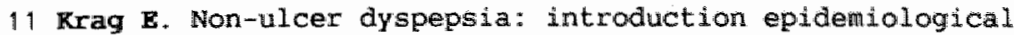
data. Scand J Gastroenterology 1982;17 (supplement): 6-8.

12 Iance $\mathbf{P}$, Filipe MI, Schiller $\mathbf{K}$. Cámetidine for non-ulcer dyspepsia. Gastroenterology 1981;80:1203.

13 Talley NJ, McNeil D, Hayden A, Piper DM. Randomised double blind placebo controlled trial of cimetidine and pirenzepine in non-ulcer dyspepsia. Gastroenterology $1986 ; 91: 149-56$.

14 Siurala $M$, Isokoski M, Varis $K$, Kekki M. Prevalence of gastritis in a rural population. Scand J Gastroenterology $1968 ; 3: 211-23$.

15. Kekki M, Villako $K$, Tamm A, Siurala $\mathbf{M}$. Dynamics of antral and fundal gastritis in an estonian rural population sample. Scand J Gastroenterology $1977 ; 12: 321-4$.

16 Kreuning J, Bosman FT, Kuiper G, MaI AM, Lindeman J. Gastric and duodenal mucosa in healthy indiwiduals. I Clin pathol $1978 ; 31: 69-77$.

17 Siurala M, Varis K. Gastritis. In: Sircus, AN Smith ed. Scientific foundations of gastroenterology williams Heinemann London $1980: 357-69$.

18 Joffe SN, Rao SS. Symptoms of gastritis. Scand J Gastroenterology 1982:17 (supplement):62-5.

19 Adami Ho, Agenas $I$, Gustavsson $\mathbf{S}$ et al. The clinical diagnosis of gastritis. Scand J Gastroenterology 1984;19:216 19.

20 Talley NJ, McNeil D, Hayden A, Colreavy C, Püper DW. Prognosis of chronic unexplained dyspepsia: a prospective study of potential predictor variables in patients with endoscopically diagnosed non-ulcer dyspepsia. Gastroenterology 1987;92:1060-6.

21 Strickland RG, Mackay IR. A reappraisial of the nature and significance of chronic atrophic gastritis. Dig Dis $1973 ; 18: 426-40$.

22 Wyatt JL, Dixon MF.Chronic gastritis: a pathogenetic approach. J Pathol 1988;154:113-24.

23 Whitehead $R$. Mucosal biopsy of the gastrointestinal tract. In: Jí Benington ed. Major problems in pathology vol III 2nd ed. Philadelphia ws slaunders 1979:15.

24 Glass GEJ, Pitchumani CS. Atrophic gastritis. Hurn Pathol $1975 ; 6: 219-50$.

25 Marshall BJ, warren JR. Unidentified curved bacilli in the stomach of patients with gastritis and peptic ulceration. Lancet $1984 ; 1: 1311-5$.

26. Jones DH, Lesselg AM, Eldridge J. Campylobacter-like organisms on gastric mucosa: culture histological and serological studies. J Clin Pathol 1984;37:1002-6. 
27 Rollabon ancosopic biopeies of the human stomach. I Clin Pathol $498: 37: 23-6$

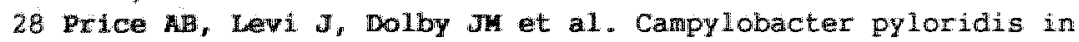
peptic ulcex disease: microbiology, pathology, and scanning electron witroscopy. Gut $1985 ; 26: 1183-8$.

29 ofconnox HI, Dixon HF, wyat sL et al. Effect of duodenal vilcer surgery on Campylobacter pyloridis-the role of enterogastric retlux. Lancet $1986 ; 1$ i: $1178-81$.

30 O'Connor HI, Dixon MP, Wyatt JL, Axon ATR. Campylobacter positive and campylobacter negative ulcers-have they different aetiology? Gut $1966 ; 27: 1282$.

31 Villako $K$, Kekki $N_{\text {, Tamm }} \mathrm{et}$ al. Epidemology and dynamics in a representative sample of an Estonian urban population. Scand I Gastroenterology $1982 ; 17: 601-7$.

32 Langenberg Mt, Tytgat GNJ, Schipper ME, Rietra $\mathbf{P J}$, Zanen HC. Campylobacter-1ike organisms in the stomach of patients and healthy indifiduals. Lancet $1984 ; 1: 1348-9$.

33 Barthel JS, Westblom 'T, Heary AD, Gonsalez F, Everet ED. Gastritus and Campylobacter pylori in heal thy asymptomatic volunteers. Arch Int Med 1988;148:1149-51.

34 0'Connor HJ, Axon ATR, Dixon MF. Campylobacter-like organisms unusual in type (pernicious anemia) gastritis. Lancet $1984: 1: 1091$.

35. Krienitz Weber das Auftreten von Mageninhalt bei Carcinoma Ventriculi. Dtsch wed Wochenschr 1906;22:872.

36 Rosenow EC, Sandford AH. The bacteriology of ulcer of the stomach and duodenum in man. J Infect Dis 1915;17:219-26.

37 Doenges Jt. Spirochetes in the gastric glands of Macacus rhesus and man without related disease. Arch Pathol 1939;27:469-77.

38 Freedburg AS, Barron LE. The presence of spirochetes in human gastric mucosa. Am J Dig Dis 1940;7:443-5.

39 Palmer $\mathbf{E D}$. Investigations of the gastric mucosa spirochetes of the human. Gastroenterology $1954 ; 27: 218-20$.

40 Steer HW, Collin-Jones DG. Mucosal changes in gastric ulceration and their response to caxbenoxalone sodium. Gut $1975 ; 16: 590-7$.

41 Warren JR, Marshall BJ. Unidentified curved bacilli on gastric epithelium in active chronic gastritis. Lancet 1983;i:1273-5.

42 Marshall EJ, Goodwin CS. Revised nomenclature of Campylobacter pylorid1s. Int I Syst bacteriol 1987;92:1518.

43 Buck GR, Gourley WK, Lee WK, Subramanyam K, Latimer JM, DiNuzo AR. The relation of Campylobacter pyloridis to gastritis and peptic ulcex. I Infect Dis 1986;153:664-9.

4 Marshall H, Royce ${ }_{4}$, Arneer DI et al. Original isolation of Campylobacter pyloridis trom human gastric mucosa. Microbios Letters $1984 ; 25: 83-8$.

45 Krajden S, Bohnen I, Anderson J et al. Comparison of selective and nom selective media for recovery of Campylobacter pylori from antral biopsies. J Clin Microbiol $1987 ; 25: 1117-8$.

46. Marshall BJ, HcGechie DB, Rogers DA, Glancy RJ. Pyloric Campylobacter infection in gastroduodenal disease. Med J Austr $1985 ; 142: 49-44$. 
47 Mchulty CAM, Watson DH. Spiral bacteria in the gastric antrum. Lancet $1984 ; i$ : 1068-9.

48 Luck JM, Seth TW. Gastric urease. Biochen J 1924;18:1227-31.

49 Goodwin CS, McCulloch RK, Armstrong JA, wee SH. Unusual cellular fatty acids and distinctive ultrastructure in a new spiral bacterium ( Campylobacter pyloridis) from the human gastric mucosa. J Med Microbiol 1985;19:257-67.

50 Collin $M D$, Costas M, Owen RJ. Isoprenoid quinone composition of representatives of the genus Campylobacter. Arch Microbiol $1984 ; 86: 575-82$.

51 Goodwin CS, Blincow $\mathbf{E}_{y}$ Armstrong $J$, McCulloch $R$, Collins D. Campylobacter pyloridis is unique: GCLO-2 is an ordinary Campy lobacter. Lancet $1985 ; 2: 38-9$.

52 Pearson $A D$, Ireland $A$, Bamforth $J$, Walker $G$, Booth $L$, Hawt in P, Holdstock G, Millard-Sadler H. Polyacrilamide gel electrophoresis of spiral bacteria from the gastric antrum. Lancet $1984 ; i: 1349-50$.

53 Goodwin CS, Armstrong JA, Marshall BJ. Campylobacter pyloridis, gastritis and peptic ulceration. J Clin Pathol $1986 ; 39: 353-65$.

54 Romaniuk PJ, zoltowska B, Trust $\mathbf{T J}$ et al. Campylobacter pylori, the spiral bacterium associated with human gastritis is not a true Campylobacter sp. J Bacteriol 1987;169:2137-41.

55 Price $\mathbf{A B}_{f}$ Dolby JM, Dunsicombe PR, Stirling J. Detection of Campylobacter by immunofluorescence in stools and rectal biopsies of patients with diarrhoea. J Clin Pathol $1984 ; 37: 1007-13$.

56 Mckulty CAM, Dent $J$, Wise R. Susceptibility of clinical isolates of Campylobacter pyloridis to 11 antimicrobial agents. Antimicrob Agents Chemother $1985 ; 28: 837-8$.

57 mckulty CAM, Gearty JC, Crump B et al. Campylabacter pyloridis and associated gastritis: investigator blind placebo controlled trial of bismuth salicylate and erythromycin ethylsuccinate. Br Med J 1986;293:645-9.

58 Glupczynski $\mathbf{Y}$, Burette $\mathbf{A}$, Labbe $\mathbf{M}$, Deprez $\mathbf{C}$, Reuck $\mathbf{M}$, Deltenre M. Campylobacter pylori associated gastritis: a double blind placebo controlled trial with amoxycillin. Am J Gastroenterology $1988 ; 83: 365-72$.

59 Rauws EAJ, Langenberg $w$, Houthof HJ, zanen HC, Tytgat GNJ. Campylobacter pyloridis-associated chronic active gastritis. Gastroenterology $1980 ; 94: 33-40$.

60 Baskerville A, Newell DG. Natural occurring chronic gastritis and Campylobacter pylori infection in the rhesus monkey: a potential model for gastritis in man. Gut $1988 ; 29: 465-72$.

61 Jones DM, Curry A. Ultrastructural study of gastric Campylobacter-like organisms (GCLO) from man, baboon, pig, and ferret. In: Campylobacter IV. Proceedings of the 4 th International Workshop on Campylobacter Infections In Press Kopenhagen 1987.

62 Hazell SL, Lee A, Brady L, Hennessy w. Campylobacter pyloridis and gastritis: association with intercellular spaces and adaption to an environment of mucus as important factor in colonization of the gastric epithelium. I Infect Dis $1986 ; 153: 658-63$. 
63 Philips $\mathrm{AD}$, Hine $\mathrm{KR}$, Holmes GKr, hoodings DF. Gastric spiral bacterial. Lancet $1984 ; 11: 100-1$.

64 Warsha11 Bi, Armstrong JA, Hecechie DB, Glancy RJ. Attempts to fulfill Koch's postulates for pyloric Campylobacter. Med I hust $1985 ; 142: 436-9$.

65 Morrda A, Nicholson G. Ingestion of Campylobacter pyloridis causes gastritis and raised fasting pH. Am J Gastroenterology $1987 ; 82: 192-9$.

66 Lambert JR, Borromeo H, Turner H, Korman MG, Hansky $H$ Colonization of gnotobiotic piglets with Campylobacter pyloridis. Gastroenterology 1987;92:1489.

67 Kaldor J, Tee J, NcCarthy P, Natson J, Dwyer B. Immune response to Campylobacter pyloridis in patients with peptic ulceration. Lancet $1985 ; 1: 924$.

68 Hazell SL, Lee A. Campylobacter pyloridis, urease, hydrogen ion back diffueion and gastric ulcers. Lancet 1986;1i:15-7.

69 Slomiany BL, Bilski. J, Munty uL et al. Campylobacter pyloridis degrades mucin and undermines gastric mucosal integrity. Gastroenterology $1987 ; 92: 1645$.

70 Gledhill T, Leicester RJ, Addis $B$ et al. Epidemic hypochlorhydria. Br Med J 1985;290:1383-6.

71 Ramsey EJ, Carey KV, Peterson WL et al. Epidemic gastritis with hypochlorhydria. Gastroenterology 1979;76:1449-57.

72 Peterson WL, Lee $\mathbf{E}$, skoglund $\mathbf{M}$. The role of Campylobacter pyloridis in epidemic gastritis with hypochlorhydria. Gastroenterology 1987;92:1575.

73 Rathbone $\mathrm{BJ}$, Wyatt $\mathrm{JL}$, Worsley $\mathrm{BW}$ et al. Systemic and local imnune responses to gastric Campylobacter pyloridis in non -ulcer dyspepsia. Gut $1986 ; 27: 642-7$.

74 Booth $L$, Holdstock $G$, MCBride $H$ et al. Clinical importance of Campylobacter pyloridis and associated serum IgA and IgG antibody responses in patients undergoing upper gastrointestinal endoscopy. I Clin Pathol 1986;39:215-9.

75 Wyatt JL, Rathbone BJ, Heatley RV. Local immune response to gastric Campylobacter in non-ulcer dyspepsia. J Clin Pathol $1986 ; 38: 863-70$.

76 Wyatt JL, Rathbone BJ. Local immune responses to Campylobacter pyloridis. In: Campylobacter IV. Proceedings of the 4 th International Workshop on Campylobacter Infections In Press Kopenhagen 1987.

77 Leunk RD, Johnson PT, David BL, Kraft WG, Morgan DR. Identification of cytotoxic activity produced by Campylobacter pyloridis. In: Campylobacter IV. proceedings of the 4 th International Workshop on Campylobacter Infections In Press Kopenhagen 1987. 
CAMPYLOBACTER ASSOCIATED GASTRTTIS IN PATTENTS WTTH NON-ULCER DYSPEPSIA
R.J.L. . . Loffeld*
H.V.P. J.Potters**
J.W. Arends**
E. Stobberingh***
J.A. Flendrig*
J.P. van Spreeuwel*

Departments of Internal Medicine*, Pathology** and

Microbiology***, University Hospital Maastricht

Published in the Journal of Clinical Pathology 1988;41:85-88 (with permission of the publisher). 
Gastric biopsy specimens from 109 patients with non-ulcex dyspepsia were prospectively examined. Sixty one patients had gastritis and there was a strong correlation with the presence of Campylobacter pyloridis. Ninety eight percent were positive in large numbers for Campylobacter pyloridis by histological examination of by culture, or both. Of 48 patients with normal histological results, 21 had evidence of campylobacter pyloridis by histological examination or culture, or both, but in small numbers. It is concluded that there is a quantitative rather than a qualitative association between Campylobacter pyloridis and gastritis.

\section{INTRODUCTION}

Every year about $1 \%$ of the total population will seek medical advise about upper abdominal complaints [1]. In about two thirds of these patients peptic ulcer, oesophagitis, active duodenitis, or gastric and oesophageal cancer are diagnosed. In one third, however, upper gastrointestinal endoscopy or X-ray picture fail to show disease. These patients are therefore diagnosed as having so called non-ulcer dyspepsia. This group of patients is heterogenous, has disorders such as gallstones and motility disorders like the irritable bowel syndrome [2], and is notoriously difficult to manage. Histological examination will often show the presence of gastritis [3-5].

Marshall and Warren's report on Campylobacter-like organisms subsequently designated Campylobacter pyloridis and their association with gastritis [6], renewed interest in this condition [79]. The nature of this association remains controversial $\llbracket 10,12 \rrbracket$, but it has been shown that drugs active against campylobacter pyloridis can cure gastritis [13]. As yet no exact data are available on the prevalence of Campylobacter pyloridis associated gastritis among patients with non-ulcer dyspepsia. We therefore studied prospectively the presence of Campylobacter pyloridis in gastric mucosa of these patients by histological and 
microbiological examination, in the hope of identifying a subgroup of patients who would possibly benefit from antimiciobial treatment.

\section{PATIENTS AND METHODS}

We studied 109 consecutive patients referred to the endoscopy department because of upper abdominal pain. Patients with gastric or duodenal ulcers, reflux desophagitis, active duodenitis, gastrectomy and carcinoma were excluded. Also excluded were those who had taken corticosteroids, non-steroidal anti inflammatory drugs, and antibiotics up to two weeks before endoscopy.

A standard history was taken from all patients using a guestionnaire, which included current complaints, smoking habits, alcohol consumption, medication and family history of upper abdominal complaints and peptic ulcer disease (tablei).

One hundred and nine patients were included, 50 men (mean age 43.3 years, range 18-75) and 59 women (mean age 56.5 years, range 16-82). All patients underwent upper gastrointestinal endoscopy with an olympus GIF Q gastroscope. The macroscopic appearance of the upper gastrointestinal mucosa was recorded and biopsy specimens were taken from the gastric antrum for culture and histological examination.

\section{Histology}

Two biopsy specimens were fixed in Bouln's fixative. Section were stained with Haematoxilin and Eosin for histological grading of gastritis according to the modified whitehead classification [14] (table 1). Blopsy specimens showing features consistent with grades 2 and 3 were regarded as showing gastritis, whereas grades 0 and 1 were regarded as morphologically normal.

Sections for histological detection of Campylobacter-1ike microorganisms were stained according to the warthin and starry method [15] and with a modified Giemsa stain $[12,16,17]$.

All sections were investigated by two pathologists 
independently, without prior knowledge of the patients complaints, gastroscopic findings, or culture results. At least 10-15 microscopic fields were examined for the presence of the typical rod-like Campylobacter-like organisms in the mucus overlying the mucosa; if Campylobacter-like organisms were not grade 2 or 3 the whole biopsy specimen was examined. For the semiquantitative grading, the following criteria were used: grade 0 , no bacteria detectable; grade 1 , sporadic bacteria observed; grade 2, clusters of bacteria seen in most microscopic fields at high power magnification $(x 400)$; and grade 3 , numerous microorganisms found in the superficial mucus layer in all fields examined.

Table 1
Gradified Whitehead classification of gastritis
Grade 1: $\quad \begin{aligned} & \text { Normal histology } \\ & \text { Slight increase of mononuclear cells in the lamina } \\ & \text { propria of the gastric mucosa, but within normal }\end{aligned}$
limits
Increase in mononuclear and polynuclear cells in
the lamina propria of the gastric mucosa
tncrease of mononuclear and polynuclear cells in
the lamina propria of the gastric mucosa, presence
of intraepithelial polynuclear cells

\section{Microbiology}

One biopsy specimen was put in sterile saline 0.98 and then transported to the microbiology department for culture. The biopsy specimens were incubated on a blood-agar medium of 6 ? sheep blood under micro-aerophilic conditions (carbon dioxide 108, oxygen 58) for five to seven days at 37 degrees Celsius. The culture was regarded as positive when typical colonies of Campylobacter pyloridis were seen. If the culture did not show growth after seven days it was regarded as negative. 
The patients were divided into two groups. Group A comprised all patients $(n=61)$ who had gastritis (Whitehead grades 2 and 3 ). In all but one the presence of Campylobacter pyloridis was shown histologically or by a positive culture, or both. Campylobacterlike organisms were classified as grade 2 and 3 in 40 (768) and grade 1 in 20 (33\%). Culture was positive in 36 (59\%) (table 2$)$. Group B comprised all patients $(n=48)$ with normal gastric histological results (Whitehead grades 0 and 1). This group was further divided into two subgroups, one with and one without the presence of Campylobacter pyloridis either by culture or histological examination. In 22 (436) patients Campylobacterlike organisms were detected (grades 2 and 3 in 4 (19\%) and grade 1 in $18(818))$. Culture was positive in 3 (7\%). In ald sections, however, the morphology and sites of the bacteria were characteristic of Campylobacter pyloridis. In both groups one positive culture failed to show Campylobacter-1ike organisms. These two cases were regarded as sampling errors and were graded as 1 for further analysis.

We found no correlation between a positive culture and the semiquantitative presence of Campylobacter pyloridis as (56\%) of positive cultures had Campylobacter pyloridis of grades 2 and 3 in the slides and $(44 \%)$ grade 1 .

\begin{tabular}{|c|c|c|}
\hline Table 2 & $\begin{array}{l}\text { d presence of } \\
\text { ween brackets }\end{array}$ & $\begin{array}{l}\text { Campylobacter pyloridis } \\
\text { represent percentages) }\end{array}$ \\
\hline $\begin{array}{l}\text { Patients with } \\
\text { non-ulcer } \\
\text { dyspepsia } \\
(\mathrm{n}=109)\end{array}$ & $\begin{array}{l}\text { results of } \\
\text { histological } \\
\text { examination }\end{array}$ & $\begin{array}{l}\text { results of } \\
\text { microbiological } \\
\text { examination }\end{array}$ \\
\hline
\end{tabular}

grade0 gradel grade2-3 positive negative

\begin{tabular}{|c|c|c|c|c|c|}
\hline \multicolumn{6}{|l|}{$\begin{array}{l}\text { Whitehead } \\
\text { classification }\end{array}$} \\
\hline Grade $0 \quad(n=38)$ & $20(52)$ & $16(42)$ & $2(5)$ & 0 & $38(100)$ \\
\hline Grade $1 \quad(n=10)$ & $6(60)$ & $2(20)$ & $2(20)$ & $3(30)$ & $7(70)$ \\
\hline Grade $2-3(n=61)$ & $1(2)$ & $20(33)$ & $40(66)$ & $36(59)$ & $23(41)$ \\
\hline
\end{tabular}


Wineteen questionnalres were incomplete and had to be eliminated from further analysis. We received 50 questionnaires from group and 40 from group B. No differences existed between the groups for either one of the complaints (table 3 ).

\begin{tabular}{|c|c|c|c|}
\hline & $\begin{array}{l}\text { gastritis } \\
\text { and }\end{array}$ & $\begin{array}{l}\text { normal } h \\
\text { C pylori }\end{array}$ & $\begin{array}{l}\text { histology } \\
\text { idis }\end{array}$ \\
\hline & $(n=50)$ & $\begin{array}{c}\text { positive } \\
(n=16)\end{array}$ & $\begin{array}{r}\text { negative } \\
(n=24)\end{array}$ \\
\hline Pain & 88 & 94 & 100 \\
\hline Nausea & 60 & 50 & 67 \\
\hline Vomiting & 16 & 19 & 25 \\
\hline Duration of complaints: & & & \\
\hline Years & 50 & 25 & 42 \\
\hline Months & 36 & 50 & 21 \\
\hline Weeks & 14 & 25 & 37 \\
\hline Association with eating & 50 & 25 & 33 \\
\hline Heartburn & 64 & 44 & 71 \\
\hline Burping & 64 & 69 & 79 \\
\hline Meteorism & 84 & 81 & 79 \\
\hline Food intolerance & 50 & 44 & 67 \\
\hline Weight loss> $\mathrm{kg}$ & 40 & 44 & 37 \\
\hline Appetite & & & \\
\hline Good & 68 & 75 & 54 \\
\hline Bad & 32 & 25 & 46 \\
\hline Alcohol consumption & 32 & 56 & 54 \\
\hline Smoking & 56 & 56 & 50 \\
\hline Family history of pep- & & & \\
\hline tic ulcer disease & 20 & 25 & 33 \\
\hline
\end{tabular}

There also was no difference for smoking, alcohol consumption, and family history. The macroscopic appearances during upper gastrointestinal endoscopy were normal in (80\%) of the patients, being almost equally divided among the two groups. In the remainder hyperaemia or erosions, or both, were seen.

To evaluate the most sensitive staining method for Campylobacter-like organisms we compared the warthin starry silver stain with a modified Giemsa stain (onitting the differentiation step with acetic acid). In 34 cases of Campylobacter pyloridis 
infection confirmed by culture, the Giemsa stain was positive in 33 (97\%) of cases; the warthin Starry was positive in 27 (798). All the sections were studied blind without prior knowledge of the culture results.

\section{DISCUSSION}

Our data show a prevalence of (55\%) of gastritis in patients with non-ulcer dyspepsia. This seemed to be strongly associated with the presence of Campylobacter-1ike organisms, generally in high numbers. Only one patient with gastritis showed no evidence of Campylobacter-like organisms. On the other hand we found evidence of Campylobacter-like organisms in (43\%) of patients with normal gastric histological findings, which was grade 1 in $(81 \%)$. This finding contrasts with reported data which generally indicate that Campylobacter-like organisms in the normal gastric mucosa comprise less than $108[6,7,8,18-20]$. In contrast to the findings in previous reports [9], we found a quantitative rather than a qualitative association between gastritis and the presence of Campylobacter-like organisms in gastric biopsy specimens. Moreover our results show that neither symptoms nor macroscopic appearances of the gastric mucosa can positively identify Campylobacter associated gastritis. Therefore the diagnosis ultimately relies on the histological or microbiological results of gastric biopsy specimens.

Cultures were positive in 598 of group $A$ and $7 \%$ of group $B$. The total number of positive cultures was less than the number of positive histological sections. The average percentage of positive cultures in published reports is $75 \%[6,9,18,21,25]$. Many authors, however, do not report their findings comprehensively $[10,22,26]$. These poor culture results probably reflect technical difficulties in culturing Campylobacter pyloridis as well as sampling errors incurred as only one biopsy was cultured. The high prevalence of campylobacter pyloridis in normal gastric mucosa in our cases may be explained by the use of the modified Giemsa stain. The silver staining method is the one most commonly used but it does have several drawbacks: it requires technical 
ski11, ig time consuning, and expensive. Moreover, in our experience silver precipitation in the mucus covering the gastric mucosa may interfere with the interpretation of the findings, so false negative results are possible [6]. The modified Giemsa stain, which is easy to perform, inexpensive, and lacks colour precipitations, was also more sensitive.

Our results provide no definite clues to whether Campylobacter pyloridis causes gastritis or is just an epiphenomenon. Our findings that Campylobacter-1ike organisms were present in gastric biopsy specimens of $43 \%$ of patients without gastritis may at first sight support the latter contention. These patients, however, generally show grade 1 Campylobacter-like organisms whereas higher grades were observed in patients with gastritis. It is conceivable, therefore, that in patients who do not have gastritis an equilibrium exists between Campylobacter-like organisms and immunological defense mechanisms, which, when distorted may lead to uncontrolled expansion of Campylobacterlike organisms and gastritis. The finding of antibodies directed against Campylobacter pyloridis may support this $[24,27,29]$. If and to what extend the presence of Campylobacter-1ike organisms in gastric mucosa is associated with upper abdominal complaints is still not known. Further studies investigating the effect of drugs against Campylobacter pyloridis, the morphology of the gastric mucosa, and the patients complaints will be required. Such studies are currently in progress.

\section{REFERFNCES}

1 Anonymous. Non-ulcer dyspepsia [editorial] Lancet 1986;i:1306-7.

2 Horrocks JC, de Dombal FT. Clinical presentation of patients with dyspepsia. Gut $1978 ; 19: 19-26$.

3 Davenport PM, Morgan AG, Darnborough A, de Dombal FT. Can preliminary screening of dyspeptic patients allow more effective wse of investigational techniques? Br Med J 1985; 290:217-20.

4 Adami Ho, Agenas $I$, Gustavsson $S$ et al. The clinical diagnosis of gastritis I. Scand J Gastroenterol 1984;19:216-9.

5 Tyllstrom J, Adami Ho, Agenas $I$, et al. The clinical diagnosis of gastritis II. Scand J Gastraenterol 1984;19:755-60.

6. Marshall BJ, Warren JR. Unidentified curved bacilli in the stomach of patients with gastritis and peptic ulceration. Lancet $1984 ; 1: 1311-4$. 
7 Jones DM, Lessels AM, Eldridge J. Campylobacter-like organisinis on the gastric mucosa: culture, histological, and serological studies. J Clin Pathol 1984;37:1002-6.

8 Rollason TP, Stone J, Rhodes JM. Spiral organistis in endoscopic biopsies of the human stomach. I clin pathol $1984 ; 37: 23-6$.

9 Price $A B$, Levi $J_{,}$Dollby JM et al. Campylobacter pyloridis in peptic ulcer disease: microbiology, pathology, and scanning electron microscopy. Gut $1985 ; 26: 1183-8$.

10 Marshall BJ, Armstrong JA, McGechie DB, Glancy RJ. Attempts to fulfill koch's postulates for pyloric Campylobacter. Med J Aust $1985 ; 142: 436-9$.

11 Axon ATR. Campylobacter pyloridis. What role in gastritis and peptic ulcer? Br Med J $1986 ; 293: 772-3$.

12 Rathbone BJ, Wyatt JL, Heatly RV. Campylobacter pyloridis: a new factor in peptic ulcer disease. Gut 1986;27:635-41.

13 MCNulty CAM, Geanty JC, Crump B, et al. Campylobacter pyloridis and associated gastritis: investigator blind placebo controlled trial of Bismuth-salicylate and erythromycine ethylsuccinate. Br Med J 1986;293:645-9.

14 Whitehead R. Mucosal biopsies of the gastrointestinal tract. In: Bennington $J L$, ed. Major problems in pathology. VolIII 2 nd ed. Philadelphia: WS Saunders, 1979:15.

15 Warthin AS, Starry AC. A more rapid and improved method of demonstrating spirochaetes in tissues. An J Syphilis $1920 ; 4: 97-9$.

16 Potters: HVPJ, Loffeld RJLF, Stobberingh $\mathbb{E}$, van Spreeuwel JP, Arends Jw. Rapid staining of Campylobacter pyloridis. Histopathology $1987 ; 11: 1223$.

17 Gray SF, Myatt JL, Rathbone BJ. Simplified techniques for identifying Campylobacter pyloridis. J Clin Pathol $1986 ; 39: 1279-80$.

18 von Wulffen $\mathbf{H}$, Heesemann GH, Butzow GH et al. Detection of CP in patients with antrum gastritis and peptic ulcers by culture, complement fixation test and immunoblot. J Clin Microbiol 1986;24:716-20.

19 Marshal1 BJ, Royce $H$, Anneer DI et al. Original isolation of Campylobacter pyloridis from human gastric mucosa. Microbios Letters $1984 ; 25: 83-8$.

20 Forrest JAH, Fricker CR, Girdwood RWA "Burnett RA, MacDonald JB. Campylobacter-like organisms in uncosa of patients undergoing routine upper gastrointestinal endoscopy. Br. Med J $1985 ; 291: 1137$.

21 Buck GE, Gourley wK, Lee WK, Subrmanyam JM, Latimer JM, Dinuzzo AR. Relation of Campylobacter pyloridis to gastritis and peptic ulcer. I Infect Dis 1986;153:66.

22 Eldridge $J$, Lessels AM, Jones DH. Antibody to spiral organisms on gastric mucosa. Lancet $1984 ; i: 1237$.

23 Hislop $I$, Glancy $\mathbb{R}$, Armstrong J. Histological improvement of active chronic gastritis in patients treated with De-Nol. Aust NZ J Med 1984;14:907.

24 Wyatt $\mathrm{JL}$, Rathbone BJ, Heatley RV. Local immune response to gastric Campylobacter in non-ulcer dyspepsia. J Clin Pathol $1986 ; 39: 863-70$. 
25 rytgat GN, Rawing EAJ, Langenberg kL, Houthof HJ.

Campylobacter pyloridis: the Austerdam study. Proceedings of the World Congress of Gastroenterology, Sao Paolo 1986.

Dig Dis SCi 1986;31:585.

25 Pynn BA, Zckstein RP, Piper Dw, Stiel D. Campylobacter-1ike organisfis and gastric ulcer. Med J Aust 1986;144:387-88i.

27 Raldor J, Tee W, Mccarthy $\mathbb{P}$, watson J, Dwyer B. Immune response to Campylobacter pyloridis in patients with peptic ulceration. Lancet $1985 ; 1: 921$.

28 Rathbone BJ, Wyatt $\mathfrak{J L}_{r}$ horsley Bw, et al. Systenic and local antibody responses to gastric Campylobacter pyloridis in nonulcer dyspepsia. Gut 1986;27:642-7.

29 Booth $L$, Holdstock $G$, MeBride $H$, et al. Clinical importance of Campylobacter pyloridis and associated serum IgA and IgG antibody responses in patients undergoing upper gastrointestinal endoscopy. J Clin Pathol 1986;39:215-9. 
DETECTION OF CAMPYLOBACTER PYLORI IN GASTRIC BIOPSY SPECIMENS: COMPARISON OF CULTURE, MODIFIED GIEMSA STATN, AND IMMUNOHISTOCHEMISTRY .

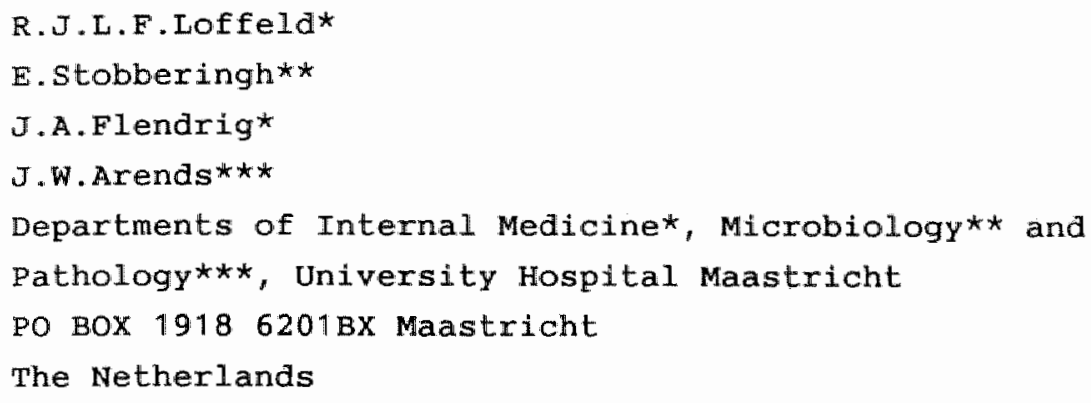

Submitted for publication. 
Antral biopsy specimens of 302 different endoscopic investigations of 200 patients with non-ulcer dyspepsia were studied for the presence of Campylobacter pylori in order to assess the most sensitive detection method. Biopsy specimens were cultured, stalned with haematoxylin and eosin, according to a modification of the Giemsa stain, and with an immunoperoxidase technique using a polyclonal rabbit anti Campylobacter pylori antiserum. Crossreactivity of this antiserum with ather Campylobacter species was neglectable.

Material from 244 investigations could be subjected to all detection methods. Culture was positive in $44 \%$, Giemsa in $78 \%$ and immunoperoxidase in $89 \%$ of these biopsy specimens. Only five positive Giemsa stains with negative immunoperoxidase stain were found, whereas in 32 cases a negative Giemsa stain with a positive immunoperoxidase stain was seen. In the latter cases the bacterial load was very low. The specimens revealed bacteria only sporadically, always confined to the deep layers of the gastric pits. Culture results correlated significantly with the bacterial load observed in the Giemsa stain. It is concluded that microbiological assessment of Campylobacter pylori is the least sensitive detection method, whereas the immunoperoxidase procedure proves to be the most sensitive means of detection. For daily practice the modified Giemsa stain, however, appears to be sufficient to diagnose the presence of the microorganism.

\section{INTRODUCTION}

There is increasing evidence that Campylobacter pylori may be a causative factor in type $B$ (antral) gastritis $[1,2,3,4,5,6]$. The diagnosis of a Campylobacter associated gastritis in patients with non-ulcer dyspepsia may be of therapeutic importance, since drugs active against Campylobacter pylori are able to reduce colonization of this microorganism with improvement of gastritis $[7,8]$. 
Precise identification of Campylobacter pylori, therefore, is an important step in the detection of campylobacter associated gastritis, especially during follow-up after therapeutical intervention.

So far, microbiological, histological, and serological methods have been widely applied for detection of Campylobactex pylori. Culture is generally accepted to be very specific. However, its sensitivity is low due to adverse influences resulting in false negative culture results [9]. Indirect assessment of campylobacter pylori is possible using breath tests, based on the urease production of the bacterium [10,11] or serological techniques $[12,13,14,15,16,17]$.

Campylobacter pylori has been studied in tissue sections stained with conventional non-specific methods, like the silver stain according to Warthin and Starry [18] "Gram's [19], modified Giemsa $[20,21]$, and acridine orange stain [22]. The specificity of these staining methods is questionable since they solely rely on the detection of microorganisms with morphological features analogous to those of Campylobacter pylori. Recognition of antigens of Campylobacter pylori is not possible.

Immunohistochemical identification of Campylobacter pylori, therefore, would be a more specific histological method of detection if a specific antibody is used.

We used an immunoperoxidase technique employing a specific anti Campylobacter pylori antiserum to detect Campylobacter pylori in antral biopsy specimens and compared its diagnostic yield with that of culture and modifled Giemsa stain in a group of patients with non-ulcer dyspepsia.

\section{PATIENTS AND METHODS}

Gastric biopsy specimens of 200 consecutive patients in whom a non-ulcer dyspepsia was diagnosed, were studied. These patients included a group of 50 patients having given informed consent for a therapeutic trial, as reported elsewhere [8]. These trial patients underwent more than one endoscopic investigation with one month interval. The group comprised of 85 men (mean age 41.4 
years, range 19-76) and 115 women (mean age 48.7 years, range $16-$ $82)$.

At upper gastrointestinal endoscopy using the Olympus GIF $Q$ gastroscope four antral biopsies were taken, one for culture of Campylobacter pylori and three for histological assessment of gastritis and campylobacter-like organisms. The total number of endoscopic investigations was 302 . All histological and microbiological detection methods could be applied in 244 cases.

\section{Hilsological examination}

Biopsy specimens were stained with haematoxylin and eosin for the assessment of gastritis according to whitehead [23] (grade 0 and 1 : normal antral histology; grades 2 and 3 showing features consistent with gastritis).

Scoring of Campylobacter pylori was performed on the basis of positive modified Giemsa [20] and/or immunoperoxidase stain. The presence of Campylobacter-like organisms was noted on a semiquantitative scale: grade 0: no bacteria seen; grade 1: sporadically some bacteria seen; grade 2 : bacteria seen in almost all high power fields $(\mathrm{x} 400)$; grade 3 : bacteria seen in all high power fields, also lying in clusters. All sections were examined blindly without knowledge of culture results. The whole biopsy specimen was examined at high power magnification (400x).

\section{Culture}

One biopsy specimen was cultured for Campylobacter pylori. It was put in sterile saline 0.98 and transported to the microbiology department. The biopsy specimen was incubated on bloodagar contalning $6 \%$ sheep blood, under micro-aerophilic conditions for five to seven days at 37 degrees Celsius. Culture was regarded as positive if typical colonies of Campylobacter pylori were seen. If the medium did not show any growth after seven days culture was regarded as negative.

\section{Anti-serum preparation}

Five different strains of Campylobacter pylori were washed 2-3 times with saline 0.98 . A bacterial suspension was made which at least contained $100 \mathrm{million}$ bacteria per ml. Two rabbits were 
inoculated with one $\mathrm{ml}$ suspension (bacterial suspension with Freud's adjuvant in a 1:1 solution). The first injection was administrated intracutaneously, after four weeks one ml bacterial suspension without Freud's adjuvant was given intramuscularly followed by a final intravenous injection of the same suspension. After this injection the rabbits were bled and the anti serum was harvested.

\section{Immunoperoxidase stain}

All available biopsy material was recut and deparaffinised with $x y l o l$ and alcohol $90 \%$ and treated with a hydrogenperoxidase methanol $0.5 \%$ solution during 15 minutes. The sections were pretreated with a pepsine solution $(0.18$ pepsine in $0.1 \mathrm{~N}$ hydrogenchloride) during 30 minutes. After cleaning with tris buffered saline the sections were preincubated with normal swine serum in a solution of $1: 5$ during 10 minutes. After incubation with primary antiserum (polyclonal rabbit antiserum, $1: 10$ solution, 45 minutes), the sections were washed three times with tris buffer. The biopsy specimens were incubated with swine antirabbit serum in a solution of $1: 150$ for 45 minutes. After cleaning with tris buffer the sections were stained (4 minutes) with 3.3 aminobenzidine tetrahydrochloride with the use of $10 \%$ imidazole to intensify the reaction. Counter staining was performed with Haematoxylin. All sections were examined semiquantitatively for the presence of Campylobacter pylori.

\section{Cross-reactivity}

The polyclonal antiserum was tested for cross-reactivity with Campylobacter jejuni, Campylobacter coli, Escherichia coli, and Enterobacter. Cultures of Campylobacter pyloril and the other microorganisms were washed with phosphate buffered saline ( 3 times). A suspension was made and $f i x e d$ in buffered formalin solution. After centrifugation for 10 minutes at $3000 \mathrm{rpm}$, this material was embedded in warm agar $(0.4$ gram agar in $10 \mathrm{ml}$ phosphate buffered saline, at 37-40 degrees Celsius). After cooling down the bacteria were embedded in paraffin. The blocks were cut with the microtome and processed with the same technique as used for normal biopsy specimens. Gram stains of the sections 
were made in order to be sure that the sections contained bacteria. Al1 sections containing enbedded bacteria were stained according to the immunoperoxidase staining technique as described in the methods section. The preparations were studied blindly ithout knowledge of the embedded bacteria.

\section{Statistical analysis}

The chi-square test was employed for statistical analysis.

\section{RESULTS}

\section{Cross-react ivity of the antiserum}

Cross-reactivity with other Campylobacter species was neglectable. It was absent with respect to other microorganisms. The polyclonal antiserum proved to be rather specific for Campylobacter pylori.

Diagnostic yield of culture, modified Giemsa stain and immunoperoxidase stain

As shown in table one immunoperoxidase stain revealed the highest diagnostic yield, 218 (898) of biopsy specimens being positive for Campylobacter pylori. Modified Giemsa stain was positive in 191 (78\%) of the cases, whereas 108 (448) biopsies yielded a pasitive culture. Culture, moreover, remained inconclusive in 18 biopsies.

\section{Table 1 Diagnostic yield of different detection methods}

$\begin{array}{lrrrrr} & \text { positive } & \text { negative } & \text { inconclusive* } & \text { total } \\ \text { culture } & 108(448) & 118(488) & 18(88) & 244 \\ \text { modified Giensa } & 191(788) & 53(228) & - & 244 \\ \text { immunoperoxidase } 218(898) & 26(118) & - & 244 \\ \text { *In these cases culture failed because of technical } & \\ \text { difficulties. }\end{array}$


one hundred eight biopsy specimens (448) showed a positive culture. All these specimens revealed Campylobacter pylori in the immunoperoxidase stain. Out of 136 biopsy specimens with a negative or inconclusive culture 110 showed Campylobacter pylori in the immunoperoxidase stain, in the remaindex ( 26 cases) no microorganisms were found.

\section{Immunoperoxidase stain and modified Giemsa stain}

one hundred eighty six biopsy specimens (76\%) showed microorganisms in the immunoperoxidase stain as well as in the modified Giemsa stain. In 32 cases (13\%) no bacteria were detected in the modified Giemsa stain, whereas the immunoperoxidase stain definitely revealed Campylobacter pylori. In these cases campylobacter pylori invariably appeared to be present in very low numbers (grade 1), always confined to the deep layers of the gastric pits (figure 2).

In 21 cases ( $8 \%$ ) both detection methods did not show microorganisms, whereas 5 (38) biopsy specimens with a positive modified Giemsa stain revealed no bacteria in the immunoperoxidase stain.

\section{Modified Giemsa stain and culture}

out of 108 positive cultures 104 (96\%) revealed Campylobacter-like microorganisms in the modified Giemsa stain, only 4 (4\%) negative stains were found. One hundred eighteen biopsy specimens did not show bacterial growth, 87 (748) of these, however, demorstrated Campylobacter-like microorganisms in the modified Giemsa stain.

\section{Culture and semiquantitative Campylobacter pylori score}

Out of 108 positive cultures $40(37 \%)$ showed grade 1 presence of Campylobacter pylori; 28 (26\%) grade 2 presence, whereas the remainder, 40 cases (37\%), scored grade 3. One hundred eighteen biopsy specimens with a negative culture showed grade $0 / 1$ presence in 87 (73\%); grade 2 in 19 (168) cases; whereas only 12 cases $(118)$ scored grade 3 . The relation between culture success rate and Campylobacter score is shown in table 2 
and appeared to be statistical significant, also when the results of inconclusive cultures were assessed to be either positive or negative.

\section{Table 2 Correlation of culture results and Campylobactex} pylori score.

Culture

positive $n=108$

negative $n=118$

$p \times 0.0001$
Campylobacter pylori score

$$
\text { grade } 0 / 1 \text { grade } 2 \text { grade } 3
$$

$40(379) \quad 28(268) \quad 40 \quad(378)$

$87(7395) \quad 19(168) \quad 12(110)$

Al1 inconclusive cultures regarded as negative:

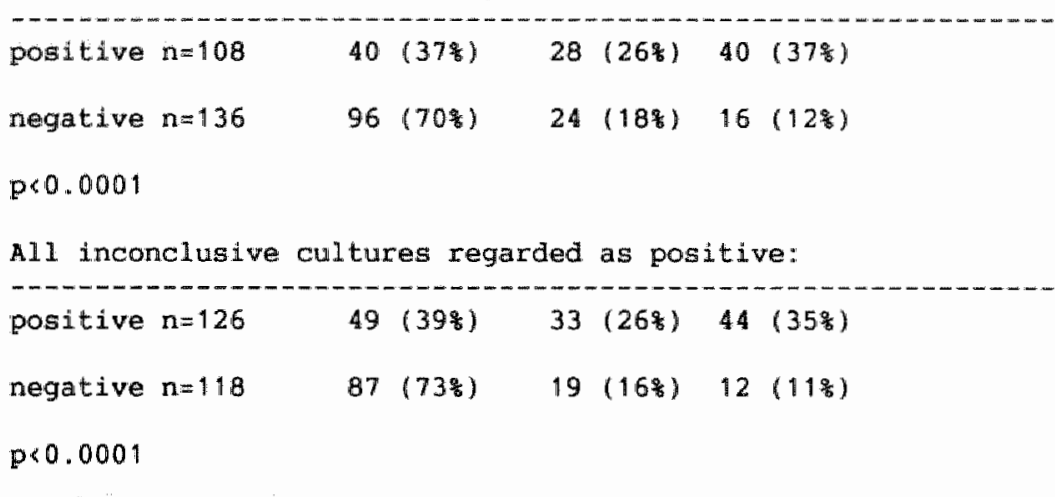

Localisation of Campylobacter pylori in the immunoperoxidase stan

Campylobacter pylori can be observed at three sites: the mucosal surface, the upper, and the lower part of the gastric pits (figures 1 and 2). Campylobacter pylori can be seen $1 y$ ing in close attachment with the mucosal surface and often is observed lying in rows (figure 2). Intracellular invasion is sometimes suggested. 


\section{DISCUSSION}

Immunoperoxidase and immunofluorescence techniques with polyclonal and monoclonal antibodies, so far, have been only employed in small groups of patients $[24,25,26,27,28]$. The results suggest that these techniques may be sensitive and specific.

The results of this large scale study confirm this impression, in that in all cases of microbiologically confirmed presence of the bacterium immunoperoxidase staining appeared to be positive indicating that the technique is sensitive. In addition cross-reactivity with other Campylobacter species and a panel of other bacteria was absent or neglectable inaicating a high specificity of the method. Most workers in the field of Campylobacter pylori research solely rely on culture for detection of Campylobacter pylori. In an earlier study, however, we reported that culture is specific but lacks sensitivity [29]. This may be explained by our observation that a significant correlation exists between culture results and the bacterlal load of the biopsy specimens. It is conceivable that false negative cultures could be due to low numbers of bacteria present in the biopsy specimen. Moreover it is known that Campylobacter pylori often exhibits a patchy distribution in the human antrum, and the number of microorganisms seen in several biopsy specimens from the same patient can vary widely. Hence it is possible that false negative histological and/or microbiological detection can occur if only one biopsy specimen is examined. This situation especial1y occurs in the group of patients showing normal histological features and low numbers of Campylobacter pylori after a course of colloidal bismuth subcitrate [8].

Although after anti Campylobacter pylori treatment improvement of gastritis has been described and the bacterium generally cannot be detected with culture $[7,30,31]$, recrudescence of gastritis appeared to occur in almost all cases. Restriction DNA analysis showed that the bacterla responsible for this recurrence are the same as before start of therapy [32], implying endogentc reinfection. Since the success rate of a culture in cases with low bacterial load is low, culture is not reliable to exclude the 
persistence of the infection after therapeutic intervention.

we already demonstrated that the modified Giensa stain is superior to the silver stain according to warthin and starry [20]. In this study we showed that the most specific staining method is the immunoperoxidase staining technique. The modified Giemsa stain, however, still remains a reliable means of detecting Campylobacter pylori in histological sections.

Only 5 (3) modified Giemsa stains were found, in which the immunoperoxidase stain failed to show Campylobacter pylori. There are two possibilities to explain this discrepancy. First the discrepant cases occurred when only low numbers of Campylobacter pylori were present. In such cases it is conceivable that the immunoperoxidase stain may be negative due to the different level of the section which was stained. Secondly the possibility exists that the curved bacilli seen in these cases belong to other spiral organisms in the human stomach. Kasper et al [31] isolated spiral organisms differing from Campylobacter pylori in 6 out of 328 patients. In a later report it is stated that these microorganisms, designated as GCLO-2, in fact are Campylobacter jejuni [34]. In a recent report tightly spiral shaped bacteria in gastric antrum are described which are urease positive but do not grow under micro-aerophilic conditions and show distinctive features at electronmicroscopic examination [35]. It is tempting to assume that the curved bacilli we observed in the modified Giemsa stain are members of these two other groups of bacteria present in the human stomach.

In all cases of positive immunoperoxidase stain and negative modified Giemsa stain, the microorganisms were found lying deep In the gastric pits. This is an area which is difficult to inspect in non-specific staining methods. In the modified Giemsa stain as well as in silver stains the bacteria show the same colour as the surrounding tissue. Because of this high background staining contrast is lacking between Campylobacter pylori and the tissue especially in the deep layers of the gastric pits. In the immunoperoxidase stain the bacteria show a brownish collour and, due to neglectible background staining, can be detected easily in these areas. 
Immunoperoxidase staining provides excellent possiblilties for studying Campylobacter pylori in its "natural" environment. In accordance with earlier work $[24,36]$ the microorganlsm coudd be detected at three sites, the mucosal surface, the upper, and the deep portions of the gastric pits.

In cases of high bacterial load the bacillus is seen at all three sites. However, if the bacterium is seen sporadically, the microorganism always is confined to the deep layers of the gastric pits.

In a number of sections we had the Impression that bacteria were lying intracellular, suggesting that cellular invasion is possible. This phenomenon already was noticed previously [9,37], and has been used as an argument for a pathogenetic effect of Campylobacter pylori on gastric epithelium.

In conclusion immunohistology provides a sensitive and specific means of studying campylobacter associated gastritis. Since almost all patients with type $B$ gastritis are positive for Campylobacter pylori, detection of the microorganism may not absolutely be required if gastritis is demonstrated on routine histological investigation. However, in cases of therapeutical intervention it is necessary, especially if normal antral mucosa is found during follow-up, not to rely on culture, but to use a specific or non-specific staining method in order to differentiate between suppression or eradication of Campylobacter pylori. Because of its rather high sensitivity and its ease the modified Giemsa stain is applicable for daily practice. For more refined detection of Campylobacter pylori, however, and for research purposes the immunoperoxidase stain is preferable.

\section{REFERENCES}

1 Marshal1 BJ, Warren JR. Unidentified curved bacilli in the stomach of patients with gastritis and peptic ulceration. Lancet $1984 ; 1: 1311-4$.

2 Rathbone BI, Hyatt JI, Heatley RV. Campylobacter pyloridis: a new factor in peptic ulcer disease? Gut $1986 ; 27: 635-41$.

3 Coodwin CS, Armstrong JA, Marshall BJ. Campylobacter pyloridis, gastritis and peptic ulceration. J Clin Pathol 1986;39:353-65.

4 McNulty CAM. Campylobacter pyloridis-associated gastritis. J Infection 1986;13:107-13. 
5 Axon ArR. Campylobacter pyloridis; what role in gastrits and peptic ulcer? Br Hed J 1986;293:772.

6 Hornick $n$. Peptic ulcer disease, a bacterial infection? New Eng I Med 1987;316:1598-1600.

7 Hohulty CAH, Geary JC, Crump $B$ et al. Campylobacter pyloridis and associated gastritis; investigator blind, placebo controlled trial of bismuth salicylate and erythromycin ethylsuccinate. Br Med J $1986 ; 293: 645-9$.

a Loffeld RuJP, Potters HVPJ, Stobberingh $\mathrm{E}$, van Spreeuwel JP, lendrig JA, Arends JW. Carnpylobacter associated gastritis in patients with non-ulcer dyspepsia: a placebo controlled trial with colloidal bismuth subcitrate. Accepted for publication in Gut.

9 Marshal1 BJ, MCGechie DB, Rogers PA, Glancy RJ. PYloric Campylobacter infection and gastroduodenal disease. Med $J$ Austr $1985 ; 142: 439-44$.

10 Graham DY, Klein PD, Evans DG et al. Rapid non-invasive diagnosis of gastric Campylobacter by a ${ }^{13} \mathrm{C}$ urease breath test. Gastroenterology 1986;90:1435.

11 Bell $\mathrm{GD}$, weil $\mathrm{J}$, Harrison $\mathrm{G}$ et all. ${ }^{14} \mathrm{C}$ urea breath analysis, a non-invasive test for Campylobacter pylori in the stomach. Lancet $1987 ; 1: 1367-8$.

12 Booth L, Holdstock $G$, MCBride $H$ et al. Clinical importance of Campylabacter pyloridis and associated IgA and IgG antibody responses in patients undergoing upper gastrointestinal endoscopy. J Clin Pathol 1986;39:215-9.

13 von Wulffen $H$, Heesemann $J$, Butzow GH, Loning $T$, Laufs $R$. Detection of Campylobacter pyloridis in patients with antrum gastritis and peptic ulcers by culture, complement fixation test and inmunoblot. J Clin Microbiol 1986;24:716-20.

14 Jones DM, Eldridge J, Fox AJ, Sehti P, Whorwell PJ. Antibody to gastric Campylobacter-1ike organisms (Campylobacter pyloridis), clinical correlations and distribution in the normal population. J Med Microbiol 1986;22:57-62.

15 Kaldor J, Tee $w$, McCarthy $\mathbf{P}$, watson J, Dwyer B. Immune response to Campylobacter pyloridis in patients with peptic ulceration. Lancet $1985 ; 11: 921$.

16 Eldridge J, Lessels AM, Jones DM. Antibody to spiral organisms on the gastric mucosa. Lancet $1984 ; 1: 1237$.

17 Rathbone BH, Wyatt JI, Worsley BW et al. Systemic and local antibody responses to gastric Campylobacter pyloridis in non-ulcer dyspepsia. Gut $1996 ; 27: 642-7$.

18 Warthin AS, Starry AC. A more rapid and improved method of demonstrating spirochaetes in tissues. Am J Syphilis 1920;4:97-9.

19 Montgomery EA, Martin DF, Peura DA. Rapid diagnosis of Campylobacter pylori by Gram's stain. Am I Clin Pathol $1988 ; 90: 606-9$.

20 Potters HVPJ, Loffeld RJLF, Stobberingh $\mathrm{E}$, van Spreeuwel JP, Arends JW. Rapid staining of Campylobacter pyloridis. Histopathology $1987 ; 11: 1223$.

21 Gray SF, Wyatt JI, Rathbone BJ. Simplified techniques of identifying Campylobacter pyloridis. J Clin Pathol 1986;39:.127980 .

22 Malters LL, Budin RE, Pau1l G. Acridine orange to identify Campylabacter pyloridis in formalin fixed paraffin-embedded gastric biopsies. Lancet 1986;i;42. 
23 whitehead $\mathbf{R}$. Mucosal biopsy of the gastrointestinal tract. In: J.L. Bennington ed. Major problems in pathology vol III 2 nd ed. Philadelphia WS Saunders 1979:15.

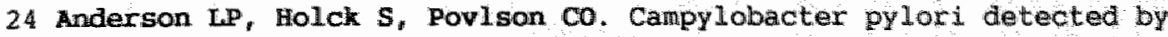
indirect immunohistochemical techniques. APMIS 1988; $96: 559-64$

25 Barbosa AJA, Quiroz DMM, Mendes NE, Rocha GA, Lima GE, Olivelra CA. Imunocytochemical identification of Camplobacter pylori in gastritis and correlation with culture. Arch Pathol Lab Med. $1988 ; 112: 523-5$.

26 Engstrand L, Pahlson $\mathrm{C}$, Gustavsson $\mathbf{S}_{\text {, Schwan A. Monoclonal }}$ antibodies for rapid identification of Campylobacter pyloridis. Lancet 1986; i1:1402-3

27 Price AB, Dolby JM, Dunscombe PR, Stirling J. Detection of Campylobacter by immunofluorescence in stool and rectal biopsies of patients with diarrhoe. J Clin Pathol 1984;37:1007-13.

28 Steer HW, Newell DG. Immunological identification of Campylobacter pyloridis in gastric biopsy tissue. Lancet 1985; 1i:38.

29 Loffeld RJLF, Potters HVPJ, Stobberingh $\mathbb{E}$, Arends JW, Flendrig JA, van Spreeuwel JP. Campylobacter associated gastritis in patients with non-ulcer dyspepsia. J Clin Pathol 1988;41:85-8.

30 Glupczynski $Y$, Burette $A$, Labbe M, Deprez $C_{\text {, Reuck }}$, Deltenre $\mathbf{M}$. Campylobacter pylori associated gastritis: a double blind placebo controlled trial with amoxycillin. Am J Gastroenterology $1988 ; 83: 365-72$.

31 Rauws EAJ, Langenberg $\%$, Houthof HJ, Zanen HC, Tytgat GNJ. Campylobacter pyloridis associated chronic active gastritis. Gastroenterology $1988 ; 94: 33-40$.

32 Langenherg $W$, Rauws EAJ, Widjojokusumo A, Tytgat GNJ, zanen HC. Identification of Canpylobacter pyloridis isolates by restriction endonuclease DNA analysis. J Clin Microbiol 1986;24:414-7

33 Kasper $G_{\text {r }}$ Dickgiesser $N$. Isolation from gastric epithilium of Campylobacter-like bacteria that are distinct from "Campylobacter pyloridis". Lancet 1985; $1: 111-2$

34 Goodwin S, Blincow $\mathbb{E}_{r}$ Armstrong J, McCulooch R. Campylobacter pyloridis is unique: GCLO-2 is an ordinary Campylobacter. Lancet $1985 ; i i: 38-9$

35 Morris A, Ali $M$, Thomson $\mathbf{L}_{\text {, Vanderwee }} \mathbf{H}_{\text {, Hollis }}$ B. Tightly spiral shaped bacteria in gastric antrum: are they urease positive? $J$ Clin Pathol $1989 ; 42: 216$

36 Hazell SL, Lee A, Bradley L, Hennessey . Campylobacter pyloridis and gastritis: association with intercellular spaces and adaptation to an environment of mucus as important factors in colonization of the gastric epithelium. J Infect Dis 1986;153:658 -63 .

37 Goodwin CS, MCCulloch RK, Armstrong JA, wee SE. Unusual cellular fatty acids and distinctive ultrastructure in a new spiral bacterium (Campylobacter pyloridis) from the human gastic mucosa. J Med Microbiol 1985;19:257-67. 


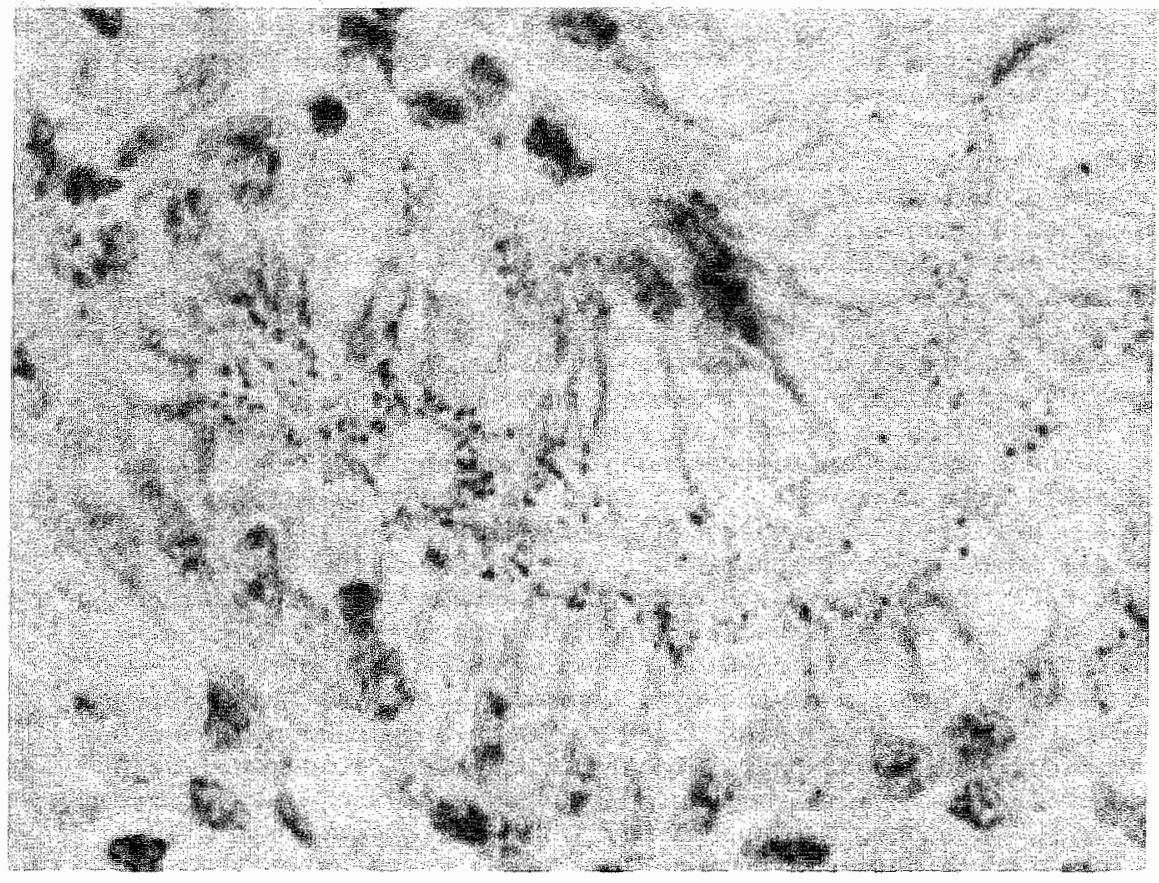

Fiqure 1: Immunoperoxidase stain showing a longitudinal section of a gastric pit with numerous campylobacters.

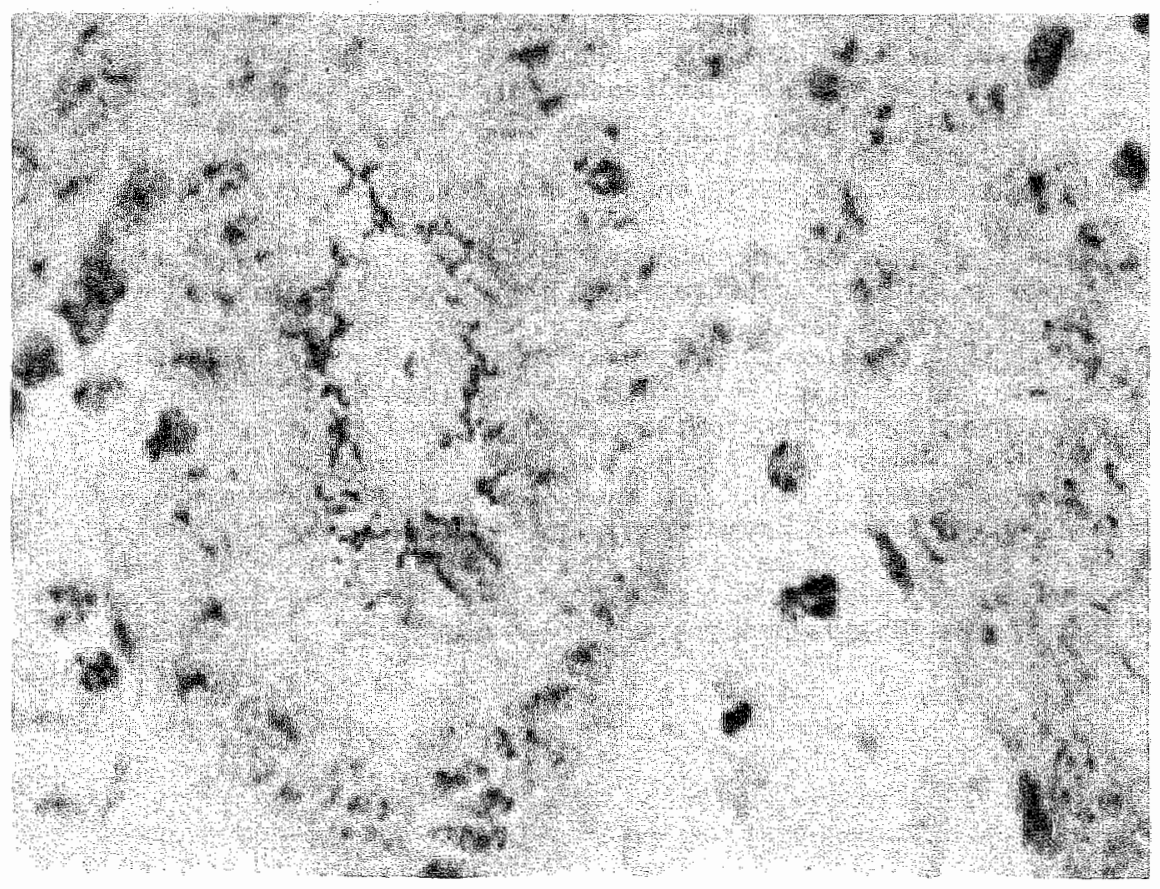

Fiqure 2: Immunoperoxidase stain showing a mid layer of a gastric pit with Canpylobacter pylori lying in rows adjacent to the epithelial cells (arrow). 
DETECTION OF ANTI CAMPYLOBACTER PYLORT ANTIBODIES FOR THE ASSESSMENT OF CAMPYLOBACTER ASSOCTATED GASTRITIS IN PATIENTS WITH NONULCER DYSPEPSIA

R.J.L.F.Loffeld MD*

E. Stobberingh PhD**

J.A.Flendrig $M D P h D^{*}$

J.P. van Spreeuwel MD PhD*\#

JW. Arends MD PhD***

Departments of Internal Medicine*, Microbiology** and Pathology $* \star *$

University Hospital Maastricht

\#present address: Department of Internal Medicine

Catharina ziekenhuis Eindhoven

Published in Lancet 1989; $1: 1182-5$ entitled: "Diagnostic value of an immunoassay to detect anti Campylobactex pylori antibodies in non-ulcer ayspepsia". 
In patients infected with Campylobacter pylori an antibody response is elicited. We used an Enzyme linked immunosorbent assay (ELISA) for detection of IgG antibodies against Campylobacter pylori in patients with non-ulcer dyspepsia and correlated these with the presence of normal antral mucosa or gastritis. No cross-reactivity with Campylobacter jejuni was found. Forty eight patients with Campylobacter associated gastritis showed a mean optical density of 3.63 (SD 1.24 ), whereas 22 patients with normal antral mucosa and absence of Campylobacter pylori on histological and microblological examination showed a mean optical density of 0.86 (SD 0.51$)(\mathrm{p}<0.0001)$. Positive predictive value for the presence of Campylobacter associated gastritis was 100\% above an optical density of 2.10 and negative predictive value was $100 \%$ below an optical density of 1.00. Given these high predictive values it is suggested that serological tests might replace endoscopy in the diagnosis of Campylobacter associated gastritis. The possible implications of this proposed diagnostic strategy in dyspeptic patients is discussed.

\section{INTRODUCTION}

Campylobacter pylori is a Gram-negative microorganism frequently found in the stomach of patients undergoing upper gastrointestinal endoscopy. Its presence is strongly associated with the presence of type $B$ (antral) gastritis $[1,2]$.

Evidence is accumulating that this association is of pathom genetic significance [3,4]. A pathogenetic role of the bacterium in type $B$ gastritis is supported by the initiation of an ant Campylobacter pylori antibody response. This antibody response can be detected both locally [5] and in the serum $[6,7]$. Presence of Campylobacter pylori is determined either by culture or histological examination of biopsy specimens, obtained through upper gastrointestinal endoscopy. To avoid the necessity of upper gastrointestinal endoscopy non-invasive tests like the urea breath tests have been developed [8]. In view of the systemic 
antibody response in patients infected with Campylobacter pylori, serological investigations may be a useful tool in the diagnosis of Campylobacter associated gastritis. Different methods of antibody detection have been used, including complement fixation tests [9], passive haemagglutination assays [10], enzyme linked immunosorbent assays [7] and immunoblot techniques [1] 11 .

The results of these studies suggest that serological tests may show a high sensitivity and specificity for the presence of Campylobacter pylori and histologically confirmed gastritis. However, in most studies patients with histologically confirmed normal antral mucosa and histologically and/or microbiologically confirmed absence of Campylobacter pylori are not included. Exact data on sensitivity and specificity values are, therefore not: always provided $[6,7,12]$. In addition cross-reactivity with other related microorganisms, most notably Campylobacter jejuni, is reported to be a problem in specific assessment of anti campylobacter pylori antibodies [13].

We developed a serological anti Campylobacter pylori IgG antibody assay to assess the antibody concentration in patients with non-ulcer dyspepsia in correlation with histological and microbiological detection of the microorganism in gastric mucosa as well as the severity of gastritis.

\section{PATIENTS AND METHODS}

Seventy patients referred to aur endoscopy department because of upper abdominal complaints were examined. Endoscopy was performed, using an olympus GIF $Q$ gastroscope. If no apparent pathology, like peptic ulceration, oesophagitis, duodenitis or gastric carcinoma was seen, biopsy specimens from the gastric antrum were taken for histological and microbiological examination. Patients using antibiotics or bismuth preparations one month prior to the examination were excluded from participation in this study.

After endoscopy a blood sample from all patients was obtained for serological investigation. 
The patients consisted of 37 men and 33 women (mean age 46 years, range $17-85$ ).

\section{Histological and microbiological examination}

Biopsy specimens were fixed in Bouin's fixative and stained with Haematoxylin and Eosin for the assessment of the gastritis score according to whitehead [14]. Presence of Campylobacter pylori was detected with culture and modified Giemsa stain, and scored as previously described $[15,16]$. Culture was performed on blood-agar containing $6 \%$ of sheep blood under micro-aerophilic conditions during at least seven days, as previously described $[16]$.

\section{Serological examination}

We used ar enzyme linked immunosorbent assay (ELISA), described by Kaldor et al. [7], to measure specific Ig G antibodies against Campylobacter pylori.

Four strains of bacteria were isolated and grown on bloodagar. When enough colonies were seen the organisms were harvested, killed at 60 degrees Celsius, sonicated and preserved with sodium azide $0.1 \%$. For the precoating of flexible polyvinyl chloride microtitre plates ( Titretek Immunoassay plates Flow Laboratories The Netherlands) 100 microliter of bacterial antigen was diluted in $60 \mathrm{mmol} / 1$ carbonate buffer pH 9,6 containing 0,18 sodium azide. For controls only buffer solution was used. The coated plates were kept at 4 degrees Celsius during 8-10 hours. The coated plates were washed four times with phosphate buffered saline (PBS). One hundred microliter of $1 \%$ bovine albumin in PBS was added during two hours after which the plates again were washed with PBS. After this procedure the plates were kept in a humid environment at 4 degrees Celsius.

For the test assay fifty microliter of diluted serum was put in the test and the control wells. After incubation at 37 degrees Celsius for 90 minutes the plates were washed four times with PBS. Then 50 microliter of peroxidase labeled anti-human immunoglobulin was added (Peroxidase-conjugated rabbit immunoglobulin to human IgG, gamma chain, DAKO immunoglobulins). After another incubation period of 90 minutes the plates were washed again and 
50 micraliter of a colour indicator (o-phenylenediamine) was added. The plates were incubated at room temperature during 30 minutes in a dark environment. The coloux reaction was stopped with 50 microliter of $4 \mathrm{~mol} / 1$ sulphuric acid. The colour was read at $492 \mathrm{~nm}$, and expressed as optical density. Control sera and blanks were included in each assay. Values for test samples were normalised with respect to the control references to correct for minor day to day variations in the assay.

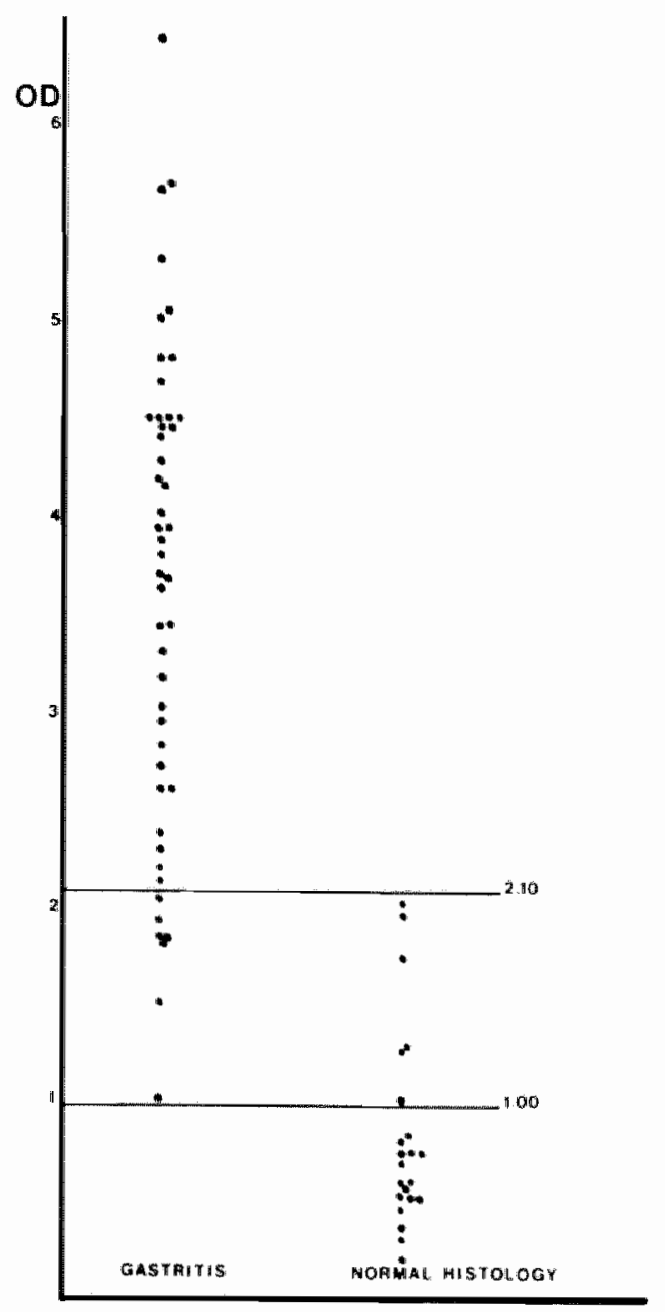

Figure 1: Horizontal axis: sera of patients from Group A (gastritis) and group $B$ (normal antral mucosa). Vertical axis: measured optical density (OD). 


\section{Statistical analysis}

Statistical analysis was performed with the chi-square test and the r-test. Sensitivity, specificity, positive and negative predictive values were calculated using the standard formula's.

\section{RESULTS}

\section{Cross-reactivity with campylobacter jejuni}

Cross-reactivity with Campylobacter jejuni was assessed with two different methods. First, sera from 21 different patients with a microblologically proven Campylobacter jejuni infection were tested in our ELISA. Mean optical density was 0.66 (SD 0.40$)$ well below the cut-off points calculated for the assessment of the presence of anti Campylobacter pylori antibodies as shown below. Second, 20 of our positive sera were tested in a specific Campylobacter jejuni ELISA [17] (courtesy of WC van DIJK, Department of Microbiology, stichting Samenwerkende ziekenhuizen Delft, the Netherlands). None of these sera showed a positive reaction in this assay.

\section{Antibody concentrations, presence of Campylobacter pylori, and}

\section{gastritis}

Forty eight patients (group A) appeared to have type B (antral) gastritis according to the Whitehead classification. Campylobacter pylori was present in all cases. Culture and/or histological examination were positive. Twenty two patients (group B) had normal antral histology. Culture and histological examination were negative for Campylobacter pylori in all cases. Figure 1 shows the optical density of both groups. The mean optical density of group $A$ was 3.63 with an SD of 1.24 , whereas the mean optical density of group $B$ was 0.86 with an SD of 0.51 $(\mathrm{p}<0.0001)$.

In figure 1 two important optical densities are delineated: the values 1.00 and 2.10 . If these values are used to diagnose Campylobacter associated gastritis we found a sensitivity of 85.4 and a specificity of $100 \%$ at the optical density of 2.10 with a positive predictive value of $100 \%$. At the optical density 
of 1.00 the sensitivity is $100 \%$ whereas the specificity is $72.7 \%$ with al negative predictive value of 100 s (table I).

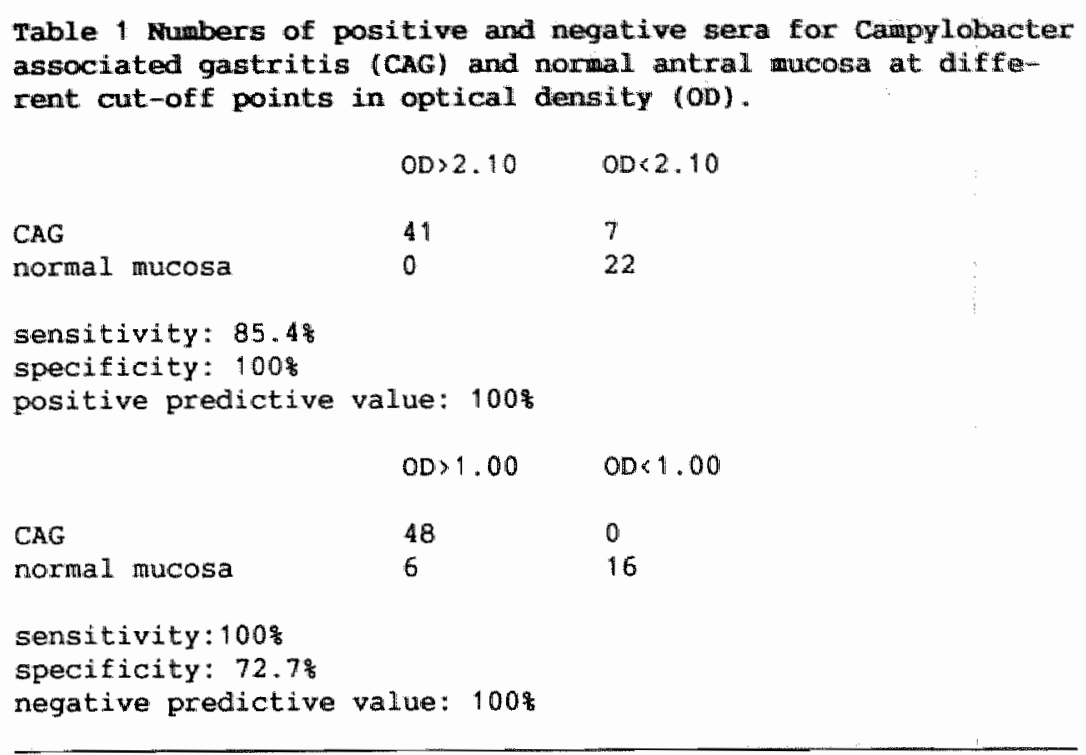

\section{Antibody concentration and severity of qastritis}

In figure 2 the two columns on the right side denote the optical density and SD for the severity of gastritis. Column A3 shows whitehead grade 3 gastritis and column A2 whitehead grade 2 gastritis. The mean value for grade 3 is 3.80 with an SD of 1.30 , for grade 2 these values are 3.10 and 1.20 respectivily (p<0.05). The ranges are 1.86-6.45 for grade 3 and $1.06-4.59$ for grade 2 respectively (figure 3 ). Using these ranges positive and negative predictive values were computed at cut-off points of 1.85 and 4.60 with respect to the severity of gastritis. At 1.85 the positive predictive value for grade 3 gastritis was $76 \%$ whereas at 4.60 this was 100 .

\section{Antibody concentrations and score of Campylobacter-like organisms}

Twenty six patients of group A showed grade 3,17 grade 2 , and 5 grade 1 Campylobacter pylori scores. The mean optical densities and standard dewiations from these patient groups were $3.52(0.93) ; 3.93(1.37) ;$ and $3.65(2.07)$ respectively, showing no significant difference. 


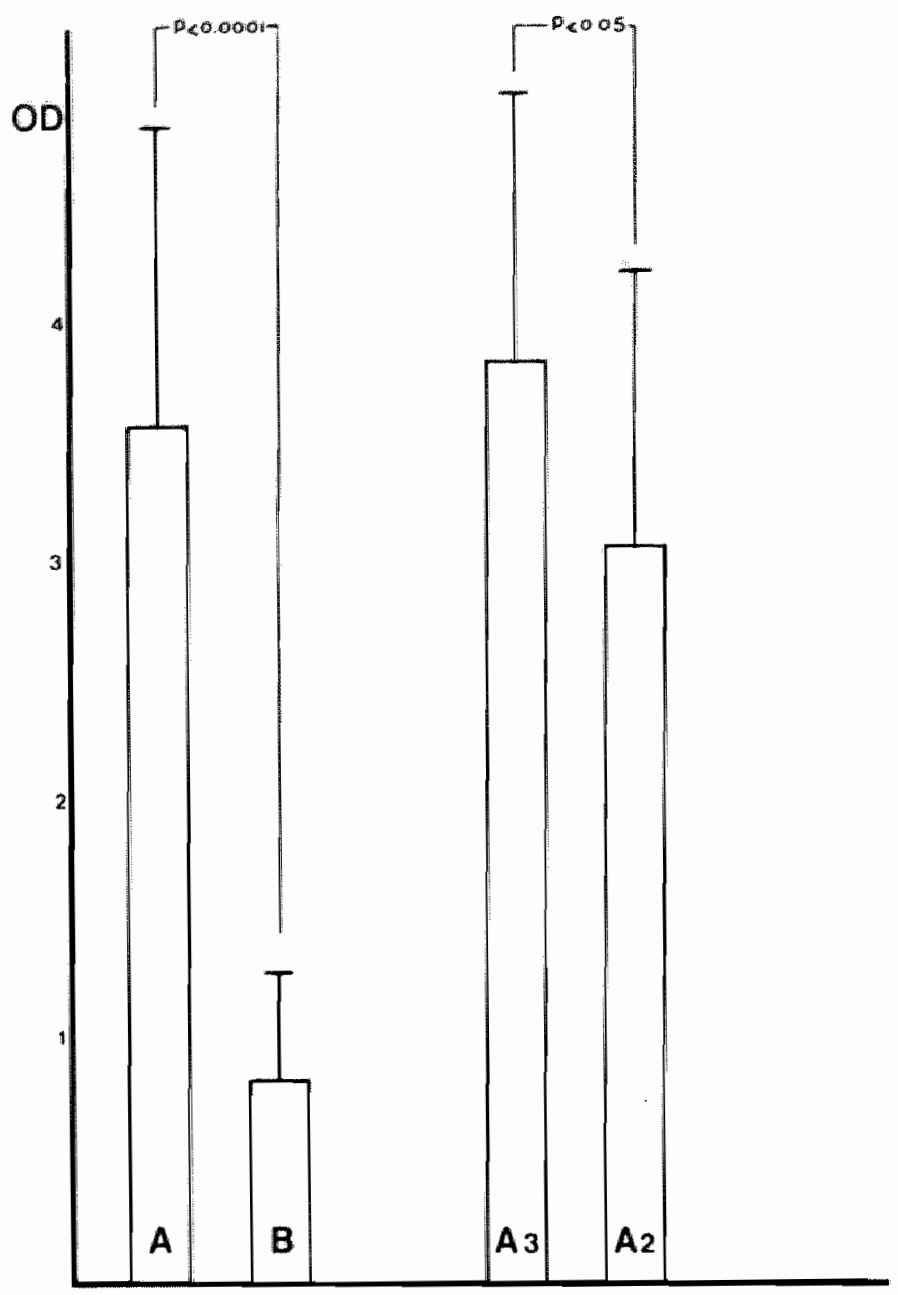

Figure 2: Mean optical density (OD) and standard deviation (SD) for the different groups. A=group $A, B=g r o u p ~ B, C o l u m n s ~ A 3$ and A2 show mean and SD for Whitehead grade 3 and grade 2 gastritis respectively.

\section{DISCUSSION}

Different methods, such as complement fixation tests $[6,12,18]$, haemagglutination assays $[10]$, and immunoblot techniques $[11,12]$ have been used to detect antibodies against Campylobacter pylori in serum. The enzyme linked immunosorbent 
assay firstly used by kaldor et al. at present is preferred by most workers in the field of campylobacter research. Three different antigen preparations have been used: whole bacteria [5], sonicated bacteria [7,19,20], and acid extracted antigens $[21,22]$. The detection of antibodies with an ELISA is reported to have a high sensitivity and specificlty value $[23,24]$.

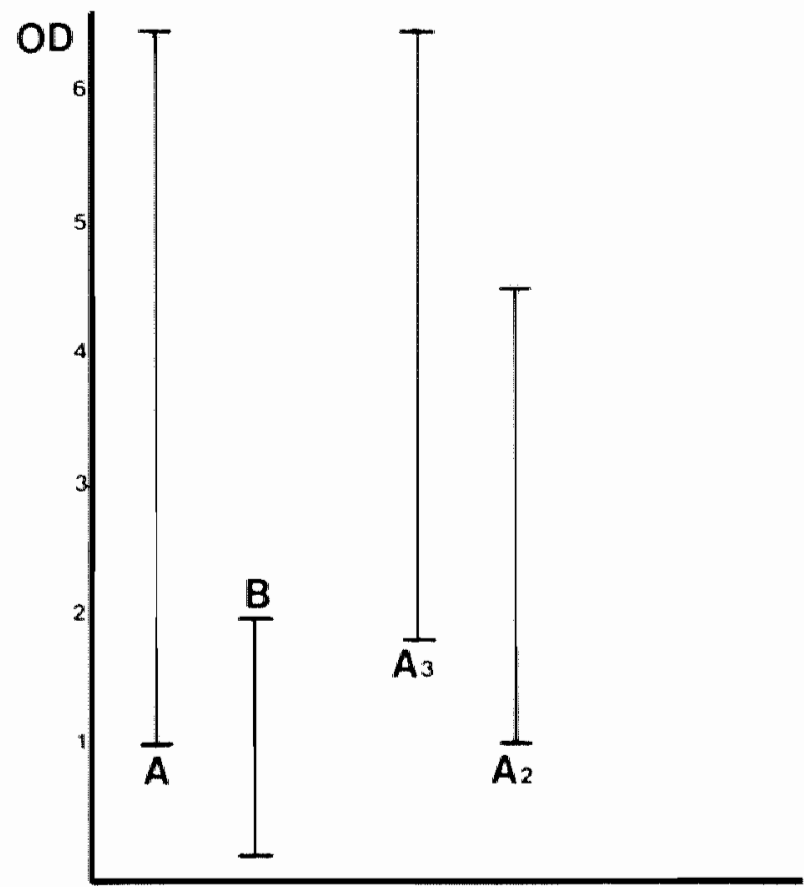

Figure 3: Minimum and maximum values of the optical dens1ty (OD) for the different groups. The columns of the diagram are the same as figure 2 .

Cross-reactivity with related microorganisms, like Campylobacter jejuni, however, has been reported to confound the results obtained in the ELISA [13]. In addition, healthy individuals or hospital staff have frequently been used as negative controls $[6,7,12,21]$, endoscopic examination often being omitted. Moreover, such persons have been shown to demonstrate Campylobacter associated gastritis in as much as $25 \%$ of the cases [23]. Also absence of the microorganism has been based on a negative 
culture, which apparentiy is not a very sensitive method of detection [16]. As a result, in general, a great overlap has been observed between the test results of Campylobacter pylori positive and negative individuals $[5,19]$.

Detection of anti Campylobacter pylori antibodies has, therefore, only been advocated in addition to endoscopy in the diagnosis of Campylobacter associated gastritis, for follow-up purposes [24], and for epidemiological studies on the prevalence of the microorganism in relation to gastritis [25].

No data, so far are available on the value of antibody detection in patients presenting with dyspeptic complaints. We have developed an ELISA technique, using a sonicated bacterial suspension, which does not demonstrate cross-reactivity with Campylobacter jejuni and shows a high positive and negative predictive value for the presence of Campylobacter associated gastritis in a selected group of patients with non-ulcer dyspepsia with and without the microorganism. In accordance with Goodwin et al. [22] the antibody titre appeared to be strongly correlated with and predictive for the grade of gastritis. There appeared to be no relation, however, with the load of Campylobacter pylori observed in the gastric biopsy specimens.

Given the high sensitivity, specificity, and predictive value of our ELISA in the diagnosis of Campylobacter associated gastritis the question may be put forward wether serological tests might replace endoscopic diagnosis of this condition. In this light it is tempting to evaluate the diagnostic value of endoscopy in the population of dyspeptic patients and to calculate the number of patients in which endoscopy could be omitted. Unfortunately in this evaluation no attention can be given to the question whether Campylobacter associated gastritis is responsible for dyspeptic complaints and it is also assumed that Campylobacter pylori infection needs treatment.

Throughout 19872200 new upper gastrointestinal endoscopies were performed because of dyspeptic complaints in our open-access endoscopy department, the outcome of which is shown in table 2 . The figures show that no apparent pathology was seen in 43.8 of the cases. Nearly half of the examined patient population in 1987, therefore after endoscopy was diagnosed as having non-ulcer 
dyspepsia according to the generally accepted exclusion criteria. These figures are in keeping with data from the literature $[26,27]$.

Table 2 Results of endoscopic investigation in the open access endoscopy department of the University Hospital Naastricht.

TotaI number 2200

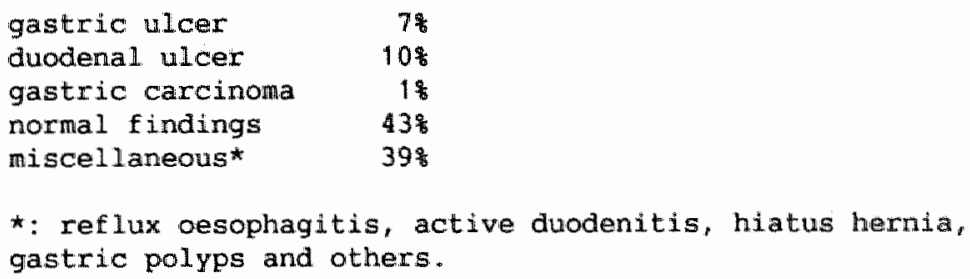

In a previous study we showed that about half of the patients with non-ulcer dyspepsia suffer from Campylobacter associated gastritis [16]. It would appear, therefore, that when antibody detection with our ELISA would have been used as a first diagnostic screening procedure for dyspeptic complaints about one quarter of upper gastrointestinal endoscopies could have been omitted. Which then would be the consequence, if a scheme as shown in figure 4 is applied in the approach of dyspeptic patients? In case of a negative outcome of the serological test gastroscopy should be performed. If in case of a positive outcome of the ELISA anti Campylobacter pylori treatment is started, the risk to initially miss the diagnosis of other pathological conditions of the upper gastrointestinal tract coincidently or necessarily accompanied by an active campylobacter associated gastritis apparently is present. This situation more specifically applies to two groups of disorders. First Campylobacter associated gastritis is present in the majority of patients with gastric and duodenal ulcers and carcinomas. From our figures the incidence, however, appears to be relatively low (17\% and 18 respectively). Moreover colloidal bismuth subcitrate as monotherapy for Campylobacter pylori [28], is known to be 
effective for peptic ulcer, whereas gastric carcinoma is frequently accompanied by other alarming symptoms such as anemia, loss of appetite, horror carnis and others, in which case upper gastrointestinal endoscopy should be performed without further delay.

Figure 4 Decision acheme using anti Campylobacter pylori ELISA as first diagnostic screening method in dyspeptic patients. The - between brackets represent the proportion of patients expected to fall in the different groups according to our experience. For other conditions these figures are unknown (?).
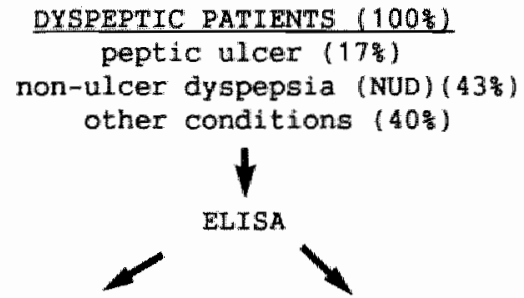

$\frac{\text { positive } 38:+? \text { ? }}{\text { peptic ulcer }(15 \%)}$

NUD (238)

other conditions (??)

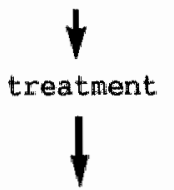

pos, result $28 \%+?$ ?

peptic ulcer (12z)

NUD (16\%)

other conditions (??)

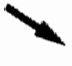

neqative $22 \%+?$ ?

peptic ulcer (2\%)

MUD (20\%)

other conditions (??)

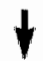

endoscopy

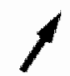

neg, result $10 \%+?$ ?

peptic ulcer (3\%)

NUD (7告)

other conditions (??)

The second group of disorders consist of reflux oesophagitis, duodenitis, hiatus hernia and others. No data so far are present, however, on prevalence of Campylobacter associated gastritis nor on the clinical significance of this infection in these conditions.

When dyspepsia persists after therapy, which according to figures from a previous study from our group [29] may be expected to occur in 308 of the cases of non-ulcer dyspepsia and 
Campy lobacter associated gastritis, gastroscopy should be considered to exclude the presence of other pathological conditions.

Figure 4 shows that based on the proportion of patients expected to fall in each group according to our experience and given the uncertainty about the prevalence and significance of Campylobacter associated gastritis coinciding with other pathological conditions resulting in dyspepsia, at least 28 of the gastroscopies in dyspeptic patients could be avolded, when the above outlined approach is followed.

We therefore conclude that this approach seems promising and might be rewarding in respect of lowering the costs of medical care and increase the diagnostic yield of endoscopy. However, before this approach can be used the prevalence of campylobacter associated gastritis in conditions other than non-ulcer dyspepsia and peptic ulcer disease should be determined and in addition the question whether Campylobacter associated gastritis needs treatment should be definitively settled. Studies directing these questions currently are in progress in our department.

\section{REFERENCES}

1 Marshall BJ, Warren JR. Unidentified curved bacilli in the stomach of patients with gastritis and peptic ulceration. Lancet $1984 ; 1: 1311-4$.

2 Price AB, Levi J, Dolby JM et.al. Campylobacter pyloridis in peptic ulcer disease: microbiology, pathology and scanning electron microscopy. Gut 1985;26:1183-8.

3 Axon ATR. Campylobacter pyloridis: What role in gastritis and peptic ulcer? Br Med J 1986;293:772-3.

4 Rathbone BJ, Wyatt JL, Heatley RV. Campylobacter pyloridis a new factor in peptic ulcer disease. Gut $1986 ; 27: 635-41$.

5 Rathbone BJ, Wyatt JL, Worsley BW et.al. Systemic and local immune responses to gastric Campylobacter pyloridis in non -ulcer dyspepsia. Gut 1986:27:642-7.

6 Jones DM, Eldridge J, Fox AJ, Sehti P, whorwell PJ. Antibody to the gastric Campylobacter-like organisms ("Campylobacter pylorids") - clinical correlations and distribution in the normal population. J Med Microbiol $1986 ; 22: 57-62$.

7 Raldor J, Tee $\mathbf{w}$, McCarthy $\mathbf{P}$, Watson J, Dwyer $B$. Immune respons to Campylobacter pyloridis in patients with peptic ulceration. Lancet 1985; i:921.

8 Bell GD, Weil $J$, Harrison $G$ et.al. $1^{4} \mathrm{C}$ urea breath analysis; a non invasive test for Campylobacter pylori in the stomach. Lancet $1987 ; 1: 1367-8$. 


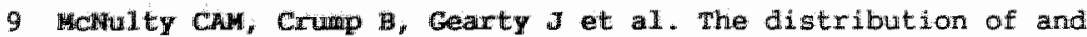
serological response to Camplobacter pyloridis in the stomach and duodenum. Campy lobecter III: Proceedings of the 3 th

International Morkshop on Campylobacter infections

London: Public Health Laboratory Services 1985:174.

10 Warshall BJ, WcGechie DB, Francis GJ, Ultley PJ. Pyloric Campylobacter serology. Lancet $1984 ; 11: 281$.

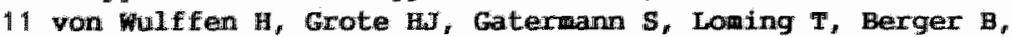
Buhl C. Im munoblot analysis of immune response to Campy Lobacter pylori and its clinical association. I Clin Pathol $1988 ; 41: 653=9$.

12 von Wuffen $H$, Heesemann $J$, Buetzow GH, Loening $T$, Laufs R. Detection of Campylobacter pyloridis in patients with antrum gastritis and peptic ulcers by culture, complement fixation test, and immunoblot. J Clin Microbiol 1986;24:716-20.

13 steer uW, Hawtin PR, Newell DG. An ELISA technique for the serodiagnosis of Campylobacter pyloridis infection in patients with gastritis and benign duodenal ulceration. Serodiagnosis. Imunother $1987 ; 1: 253-9$.

14 Whitehead $\mathbb{R}$. Mucosal biopsies of the gastrointestinal tract. In: Bennington ed. Major problems in pathology vol III 2 nd ed. Philadelphia ws Saunders 1979:15.

15 Potters HVRJ, Loffeld RJLF, Stobberingh $\mathbf{E}$, wan Spreeuwel JP, Arends JW. Rapid staining of Campylobacter pyloridis. Histopathology $1987 ; 11: 1223$.

16 Lof feld RILF, Potters HVPJ, Stobberingh E, Arends JW, Flendrig JA, van Spreeuwel JP. Campylobacter associated gastritis in patients with non-ulcer ayspepsia. J Clin Pathol $1988 ; 41: 85-8$.

17 Herbrink P, van den Munckhof HAH, Bumkens $M$, Lindeman $J$, van Dijk wC. Human serum antibody response in Campylobacter jejuni enteritis as measured with enzyme linked immunosorbent assay. Eur $J$ Clin Microbiol 1988;7:388-93.

18 Jones DM, Lessels AM, Eldridge J. Campylobacter-like organisms on the gastric mucosa: culture, histological, and serological studies. I Clin Pathol 1984;37:1002-6.

19 Booth L, Holdstock G, MCBride HM et.al. Clinical importance of Campylabacter pyloridis and associated serum IgG and IgA antibody responses in patients undergoing upper gastrointestinal endoscopy. I Clin Pathol 1986;39:215-9.

20 paull G, Dick JD, Ravich WJ et al. Serum IgG antibody to Campylobacter pyloridis: diagnostic value and correlations with gastric biopsy findings. Gastroenterology 1987;92:1569.

21 Newell DG, Johnston BJ, Ali MH, Reed PJ. An enzyme-1inked immunosorbent assay for the serodiagnosis of Campylobacter pylori associated gastritis. Scand J Gastroenterology 1988,23 (supplement 142);53-7.

22 Goodwin CS, Blincow E, Peterson G et al. Enzyme linked 1 munosorbent assay for Campylobacter pyloridis: correlation with presence of Campylobacter pyloridis in gastric mucosa. J Infect Dis $1987 ; 155: 488-94$.

23 Itangenberg MT, Tytgat GNJ, Schipper ME, Rietra PJ, Zanen HC. Campylobacter like organisms in the stomach of patients and healthy individuals. Lancet $1984 ; 1: 1348-9$. 
24 Vaira $D$, Holton $J$, Caines $S R$ et.all. Antibody titres to Campylobacter pylori after treatment for gastritis.

Br Med J 1988;297:397.

25 Graham $\mathrm{DY}$, Klein PD, Opekun AR et al. Epidemiology of Campylobacter pylori infection: ethnic considerations. Scand J Gastroenterology 1988,23 (supplement 142);9-13.

26 Anonymus. Non-ulcer dyspepsia (editiorial). Lancet 1986; i:1306-7.

27 Holdstock G, Wiseman $M$, Loehry CA. Open-access endoscopy serwice for general practioners. Br Med J 1979;1:457-9.

28 McNulty CAM, Gearty JC, Crump B et.al. Campylobacter pyloridis and associated gastritis. Investigator blind placebo controlled trial of bismuth salicylate and erythromycine ethylsuccinate. Br Med J 1986;293:645-9.

29 Loffeld RJLF, Potters HVPJ, Stobberingh $\mathbf{E}$, Flendrig JA, wan Spreeuwel JP, Arends JW. Campylobacter associated gastritis in patients with non-ulcer dyspepsia: a double blind placelio controlled trial with colloidal bismuth subcitrate. Accepted for publication in Gut. 
Publication of chapter 5 in the Lancet evoked the following reaction followed by our reply:

Sir, Dx Loffeld and colleagues' report (may 27, p 1182) on an immunoassay to detect Campylobacter pylori antibodies contains conceptual exrors which, if corrected, wight significantly alter their conclusions. Al serological tests on sonicates or crude extracts of whole $c$ pylori have suffered from frequent false positive and false negative results. Such preparations contain antigens that cross-react with antibodies directed against other bacteria (eg, c jejuni, C fetus, and Escherichia coli). Adjusting the ELISA cut-off to avoid false positives increases the false negative rate. Loffeld and colleagues found a positive predictive value off 100 at the high cutoff but with a negative predictive value of only $76 \%$. Lowering the cut-off value to 1.00 had the expected opposite effect - namely, a negative predictive value of $100 \%$ and a positive predictive value of only 89.8 . Their test is not a good discrimination between presence or absence of $\mathrm{C}$ pylori infection. Several groups have found a significant decrease in $C$ pylor antibody after absorption of sera with $C$ jejuni. and cross-reactivity can also be reduced by absorbing sera first. Loffeld et al claim that there was no cross-reactivity to $c$ jejuni but they did not directly test for it. Loffeld et al assume that optical density (OD) is proportional to antibody titre or concentration; it is not. Nor is oD (absorbance) on a linear scale such that an OD of 2 equals $1 \%$ light transmission and oD 3 equals $0.1 \%$ light transmission; their positive test is in an absorbance range that is inaccurate and should be avoided. We need accurate reliable methods ta detect $C$ pylori infection and its eradication. Several candidates are available, including the urea breath test and second-generation serological tests based on purified antigens. For example, a test based on the purified, high-molecular-weight cell-associated proteins of $\mathrm{C}$ pylori has a positive predictive value of $100 \%$ and a sensitivity and negative predictive value of $98.7 \%$. Loffeld and colleagues' "discussion" is based on the premise that there is a safe and effective therapy for $C$ pylori infection and that patients with this infection should be treated. Both premises are currently controversial. One of us (D.Y.G.) has predicted that the management of dyspepsia would change remarkably; "If $C$ pylori is conclusively proven to be the most important factor in chronic duodenal or gastric ulcer disease and also as responsible for a reasonable percentages of cases of non-ulcer dyspepsia", endoscopy and bariun series might be used much less often. A more cost-effective approach might be to screen the dyspeptic patientby, for example, a latex agglutination test for antibody to $C$ pylori urease and treat positive cases with agents against $\mathbb{C}$ pylori. Only non-responders or those at high risk of gastric cancer or with complications such as anaemia would undergo other diagnostic tests. The elimination of ulcer relapse by eradicating $C$ pylori, the availability of safe and effective therapy for $C$ pylori, and the development of simple tests to screen for $C$ pylori and to monitor the efficacy of thexapy are reasonable predictions.

David $Y$. Graham

Doyle J. Evans jn

Dolores G. Evans 
This letter has been shown to or Loffeld and colleagues, whose reply follows.

Sir, Dr Graham comments on some technical aspects of our ELISA procedure and points to some alleged conceptual errors, correction of which would significantly change our conclusions. we agree that so far serologic tests using sonicates or crude extracts of campylobacter pylori flaw from cross-reaction with other microorganisns, most notably Campylobacter jejuni. Our assay, however, did not show such cross-reaction, when sufficiently tested with indirect methods. Under these circumstances we can see no reason why direct tests should have been performed to exclude crossmreactions.

It would appear that Dr Graham did not quite get the point how the cut-off values were established. The values were derived from comparison of two well defined groups of patients with non-ulcer dyspepsia with and without Campylobacter associated gastritis, and provided clear cut-off points indicating 100 o positive and negative predictive values respectively, leaving circumvention of the problem of cross-reactivity totally aside.

We are not aware of having been stumbled into the trap of assuming that optical density is proportional to antibody titre. It is well established, though, that measured extinction values reflect the amount of antibody in the test serum. All measured values of the test sera were divided by the controls to calculate the $\mathrm{P} / \mathrm{N}$ ration on a linear scale. To rule out any source of misunderstanding on this point it would perhaps have been better if we had mentioned this $P / N$ ratio explicitely in the Iegend of figure 1.

our "discussion", indeed, was based on the premise that there is a safe and effective therapy for Campylobacter pylori and that patients with Campylobacter pylori infection should be treated. While we agree with Dr Graham's criticism on the latter part of this premise, we maintain that Campylobacter pylori infection can be safe and effectively treated with colloidal bismuth subcitrate. In this context it is surprising, however, to see from the large quotation of Dr Graham's own work, that in spite of his criticism his line of thinking almost entirely coincides with the views we expressed in our paper. We, in addition, tried to provide a provisional quantitative estimation of the decrease of endoscopies resulting from adoption of the proposed strategy based on morbiddty figures in our hospital, expressing our doubt about the necessity of treating Campylobacter pylori infection in the very last sentence of the "discussion".

Therefore, we are left with the question what conceptual errors we made. Or were Dr Graham's views subjected to dramatic change quite recently?

Loffeld RuLF, MD

Stobberingh E, PhD

Arends JW, MD PhD

University Hospital Maastricht, Po BOX 19186201 Maastricht,

The Netherlands. 
THE PREVALENCE OF ANTI CAMPYLOBACTER PYLORI ANTIBODIES IN PATIENTS AND HEALTHY BLOOD DONORS.

R.J.L.F. Loffeld*

E. Stobberingh $\star *$

J.P. van Spreeuwel*\#

J.A. Flendrig*

J.W. Arends***

Departments of Internal Medicine* "Microbiology** and Pathology*** University Hospital Maastricht \# present address: Department of Internal Medicine Catharina Ziekenhuis Eindhoven

Accepted for publication in the Journal of Medical Microbiology. 
An ELISA technique, with a sonicated suspension of Campylobacter pylori as antigen, has been used to detect anti Carmplobacter pylori antibodies in 517 patients and 401 healthy blood donors. The criterium of seropositivity was determined through a receiver operating curve computed with the values of optical density of 48 sera from dyspeptic patients with proven Campylobacter associated gastritis and 16 sera from patients with normal antral mucosa and microbiologically and histologically confirmed absence of Campylobacter pylori. The number of seropositive persons in the patient group $(227 / 517,448)$ appeared to be signiflcantly higher than the number of sera with antibodies in the blood donors tested $(142 / 401,35 \%(\mathrm{p}=0.03)$, also when stratification for age and sex was performed. In both groups a parallel increase in accurrence of seropositivity was found with rising age.

From these data we conclude that the prevalence of Campylobacter pylori infection increases with age and that although antibodies against Campylobacter pylori show a somewhat highex prevalence in patients attending a hospital compared to healthy blood donors, evidence of ongoing infection or infection in the past can be found in as much as one third of a randomly chosen population of blood donors.

\section{INTRODUCTION}

Campylobacter pylori has been implicated as a common cause of chronic active gastritis and possibly peptic ulcer disease $[1,2,3,4,5]$. Early debate as to whether campylobacter pylori is an opportunistic bacterium, attracted to inflamed antral mucosa, or can be implicated as the cause of type $B$ (antral) gastritis, tends to be resolving in favor of the latter contention [2].

older studies on the prevalence of gastritis have shown an increase with age $[6,7,8]$. Since type $B$ (antral) gastritis is almost always associated with campylobacter pylori $[1,2,3,4,5]$ increasing prevalence of this microorganism would be expected. 
As, however, diagnosis of active Campylobacter pylori infection so far relies on invasive diagnostic procedures (endoscopy and biopsy), large scale population studies are sparse. No exact data therefore are available as yet on the presence of this infection in relation to age.

Patients infected with Campylobacter pylori develop a local as we11 as systemic antibody response $[9,10,11]$. Hence serological techniques can be used for the assessment of this antibody response $[12,13]$. A previous study from our group demonstrated that presence of antibodies can be correlated with presence of Campylobacter associated gastritis [14]. It would appear therefore that detection of antibodies against Campylobacter pylori can be used for epidemiological studies in larger population groups without the necessity of upper gastrointestinal endoscopy. This would also enable to assess the prevalence of antibodies in healthy individuals and acute or chronically 111 patients, on which, only in regard to healthy persons some data are present in the $\mathbb{1}$ iterature $[15,16]$.

Against this background we performed a serological study with an ELISA technique in order to assess the prevalence of antibodies against Campylobacter pylori in healthy blood donors and patients in relation to different age cohorts.

\section{METHODS}

\section{Patients}

Two different groups of individuals were studied. The first group (group A) consisted of 517 patients: 233 men and 284 women, mean age 56 years, range 2-89. These patients comprised of a heterogenous group of in- and outpatients who had in common that they neither were examined because of dyspeptic complaints nor underwent endoscopy because of follow-up after peptic ulcer disease or for other reasons related to the upper abdominal tract. The second group (group B) consisted of 401 healthy blood donors, 362 men and 39 women mean age 42, range 19-65.

From all patients and blood donors a blood sample was obtained for serological investigation. 
As rerence population 64 patients referred for endoscopy because of dyspepsia $(35$ men, 29 women, mean age 64 years, range 17-85) were used. Of these 48 were shown to have a Campylobacter associated gastitis, whereas in 16 patients histological examination revealed normal antral mucosa while campylobacter pylori could not be detected either microbiologically nor histologicalily.

\section{Serological examination}

We used an enzyme-1inked immunosorbent assay (ELISA), described by Kaldor et.a1. [9], to measure specific Ig G antibodies against Campylobacter pylori.

Four strains of bacteria were isolated and killed at 60 degrees celsius. After sonication and preservation with sodium azide $0.1 \%$ a suspension was made and used as bacterial antigen. one hundred microliter of the suspension in a 1:50 dilution with 60 mmol/1 carbonate buffer ( $\mathrm{pH}$ 9.6, with sodium azide 0.18) was used for the precoating of flexible polyvinyl chloride microtitre plates (Titertek Immunoassay plate, Fllow Laboratories The Netherlands). The coated plates were kept at 4 degrees celsius for $8-110$ hours and washed with phosphate buffered saline (PBS, $0.5 \%$ Tween $20 \mathrm{pH} 7.1$ ). After adding $1 \%$ bovine albumin in PBS and another incubation of 2 hours, the plates were washed again with PBS. For controls only buffer solution was used. The preparated plates were kept in a humid environment at 4 degrees celsius.

For the test assay 50 microliter of patients serum ldilution 1:10 in PBS, was put in the test as well as in the control plates. The plates were washed with PBS after a 90 minutes incubation at 37 degrees Celsius. Fifty microliter of peroxidase labeled ant 1 -human immunoglobulin (Peroxidase-conjugated Rabbit immunoglobulin to human IgG, gamma chain, DAKO-immunoglobulins) was added. After another incubation period of 90 minutes the plates were washed and 50 microliter of a colour indicator ( $20 \mathrm{mg}$ o-phenylenediamine with 0.08 microliter $\mathrm{H}_{2} \mathrm{O}_{2} 30$ ) was added. After incubation at room temperature in a dark environment the colour reaction was stopped with 50 microliter of $4 \mathrm{~mol} / \mathrm{l}$ sulphuric acid. The colour was read at $492 \mathrm{~nm}$, and expressed as optical density. Control sera and blanks were included in each 
assay. The measured values for optical density were normalised with respect to the control references to correct for minor day to day variations in the assay. Cross-reactivity with campylobacter jejuni was neglectible as described elsewhere [14].

\section{Statistical analysis}

The chi-square test and the T-test were used to perform statistical analysis. Sensitivity and specificity values were analysed using the standard formula's .

\section{RESULTS}

\section{Assessment of the cut-off point}

For the assessment of the cut-off point in optical density values to discriminate between presence or absence of anti Campylobacter pylori antibodies, sera from patients of the reference population were used. Forty eight patients appeared to be positive for Campylobacter pylori on histological and/or microbiological examination (mean optical density 3.63, SD 1.24, range 1.06-6.45). The remainder, 16 patients, were negative (mean optical density 0.70 , SD 0.45, range 0.21-1.99). After computing a receiver operating curve (ROC) at the optical density of 1.50 the optimal values for sensitivity (97.98) and specificity (94.4\%) were found. An optical density above 1.50, therefore was regarded as being indicative for the presence of antibodies against campylobacter pylori, whereas an optical density below 1.50 was interpreted to be negative. Figure 1 shows the optical densities, as measured with our ELISA assay in these 64 patients. The dotted line indicates the cut-off point.

\section{Antibodies in patients and healthy individuals}

Mean optical density for seropositive patients (group A) was 2.14 (SD 0.67, range 1.51-4.13), and for seropositive blood donors (group B) 2.32 (SD 0.47 , range 1.51-3.43). There appeared to be no significant difference in optical density between both groups (figure 2). However, a significant difference in height of the optical density of the seropositive reference population with 
proven Campylobacter associated gastritis and the seropositive blood donors and patients (group $A)$ was seen (p<0.001) (figure 3 ).

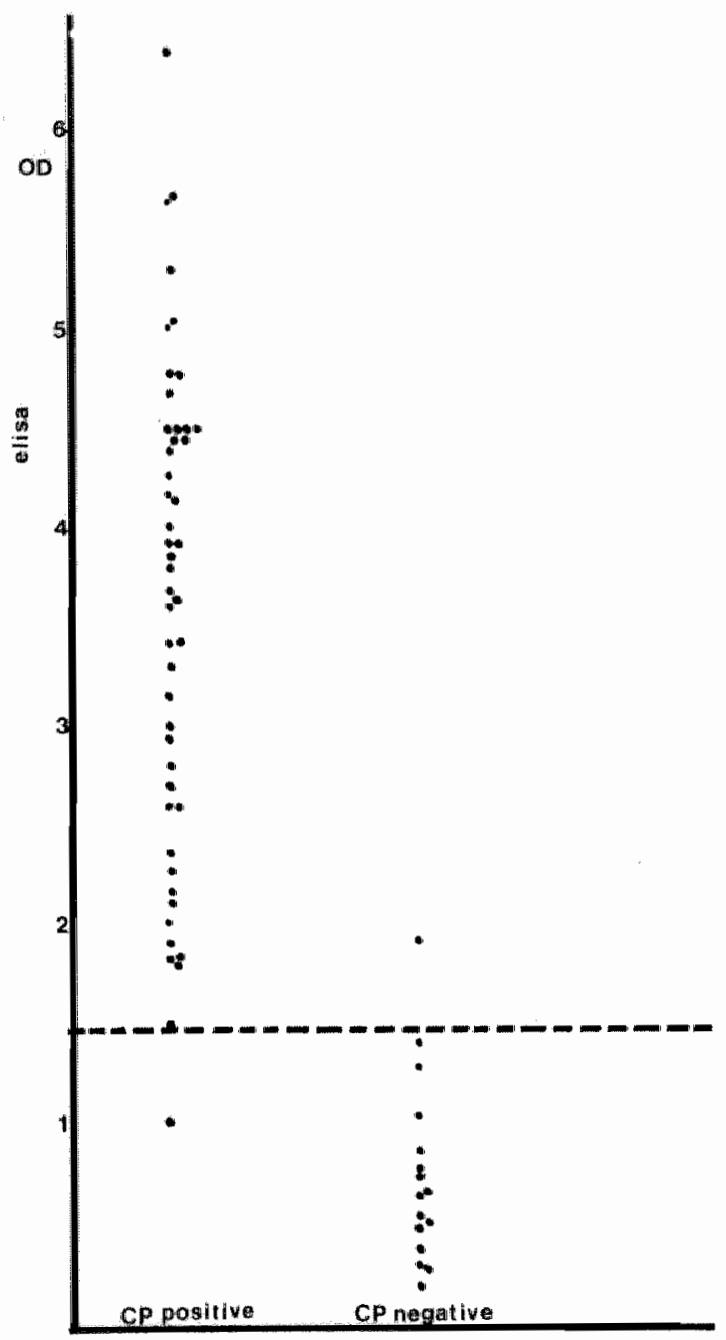

Figure 1: The measured optical densities for sera of the reference population. The values on the left side denote the sera of patients positive for Campylobacter pylori, the values on the right side denote sera from Campylobacter pylori negative patients. The dotted line indicates the cut-off point at the optical density of 1.50 as calculated with the Roc. 


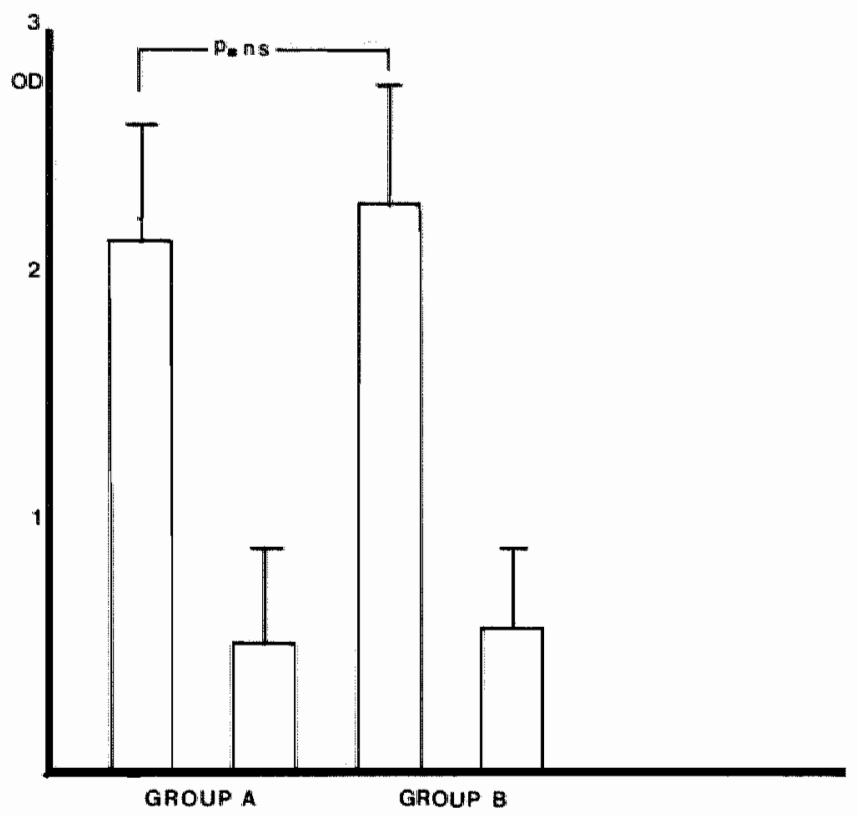

Figure 2: Mean optical density and standard deviation of seropositive and seronegative patients (group A) and healthy blood donors (group B). The column on the left side of each group indicates the positive sera, the column on the right side the negative sera.

Table 1 shows the total number of patients and blood donors with antibodies. Two hundred and twenty seven (44\%) out of 517 patients revealed positive antibody titres as against 142 out of 401 (35:) individuals of group B (p.0.03). This significant difference in occurrence of antibodies in both groups remained present after stratification for age and sex.

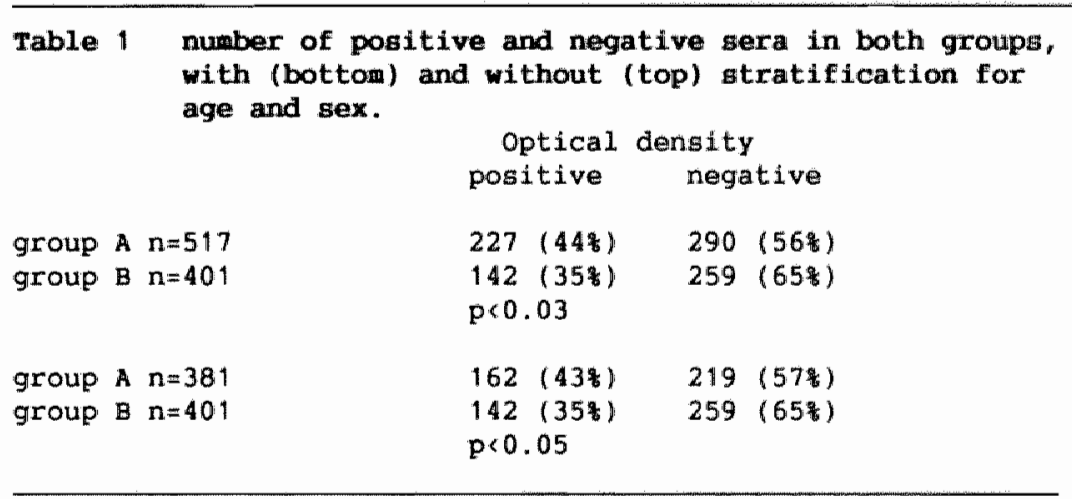




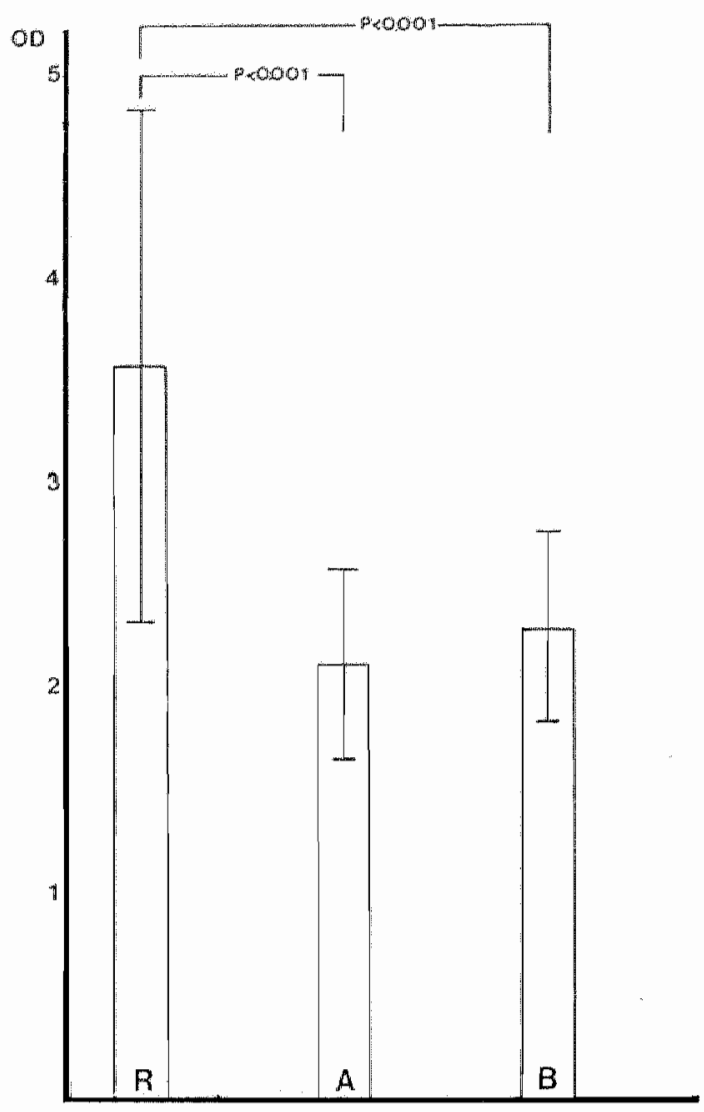

Figure 3: Mean optical density and SD for the seropositive reference population (R), patients (A), and blood donors (B).

Antibodies in different age cohorts of patients and healthy persons

In both groups a parallel rise in number of positive sera was found with increasing age. Table 2 shows the exact numbers of positive and negative sera in each age cohort, while figure 4 shows the percentages of positive sera in each age cohort graphically. 
Table 2 Numbers of positive and negative sera in consecutive age cohorts of both groups.

$\begin{array}{lcccc}\text { Age cohorts } & \begin{array}{l}\text { group A } \\ \text { positive }\end{array} & \text { negative } & \begin{array}{l}\text { group B } \\ \text { positive }\end{array} & \text { negative } \\ 0-10 & 1 & 5 & - & - \\ 11-20 & 2 & 10 & 0 & 5 \\ 21-30 & 18 & 39 & 10 & 43 \\ 31-40 & 13 & 36 & 35 & 92 \\ 41-50 & 27 & 36 & 53 & 84 \\ 51-60 & 43 & 45 & 36 & 34 \\ 61-70 & 61 & 62 & 7 & 5 \\ 71-80 & 46 & 36 & - & - \\ 81-90 & 16 & 18 & - & - \\ - & & & & \end{array}$

GROUP A

GROUP B

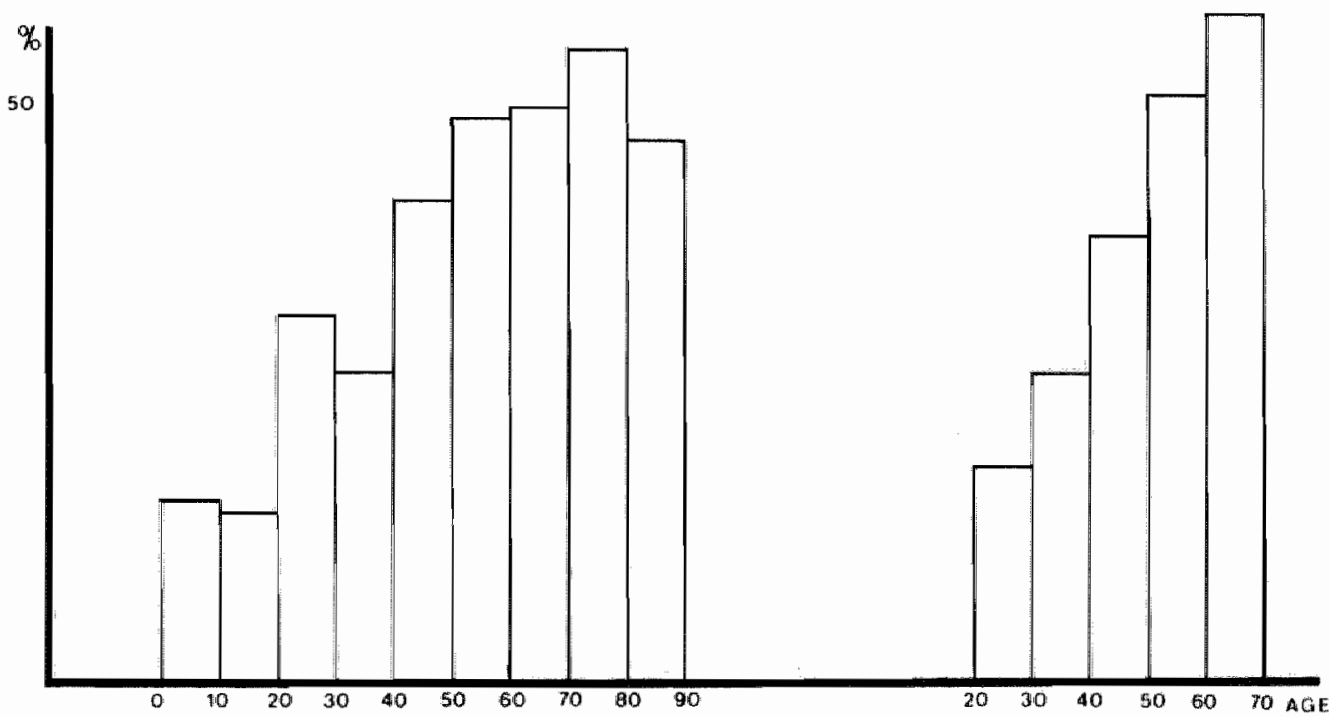

Pigure 4: Percentage of sera positive for anti Campylobacter pylori antibodies in different age cohorts of group $A$ and $B$. 
Presence of antibodies against Campylobacter pylori has previously been described in the literature in patients with histological confirmed type B (antral) gastritis $[16,17,18]$, and has therefore been used to study the prevalence of gastritis in largei population groups $[15,19]$.

Whether, however, detection of a systemic response to the microorganism implies the presence of an active Campylobacter associated gastritis remains questionable. Firstly crossreactivity with antibodies against other microorganisms, most notably Campylobacter jejuni, should not confound the results of the assay used to detect anti Campylobacter pylori antibodies. In a previous study we demonstrated that in our ELISA no such interference existed with sera from patients with a proven Campylobacter jejuni infection [14]. Secondly it is conceivable that anti Campylobacter pylori antibodies persist long after exposure with the microorganism and remain present while the initially invoked gastritis has already subsided. There are data available that show decreasing IgG antibody titers after successfull treatment of campylobacter associated gastritis $[20,21]$.

The results of the reference population reported extensively elsewhere [14] indicate that the presence of a systemic antibody response in dyspeptic patients is strongly related to active Campylobacter associated gastritis. This is also evident from the high sensitivity and specificity values found after computing a ROC at optical density 1.50 in the reference population. These data suggest that the presence of antibodies actually may reflect active Campylobacter pylori infection. However, the seropositive members of group $A$ and $B$ show a statistical significant lower optical density as compared with the dyspeptic reference population, although there is considerable overlap. Hence these results cannot be extrapolated. This indicates in our opinion that in both groups individuals are present who will have active Campylobacter pylori infection with active gastritis and individuals who are seropositive because of a campylobacter pylori infection in the past. It is conceivable to suggest that these latter individuals started with a higher optical density and that 
their gastritis has subsided because of anti campylobacter therapy given intentionally or accidently. It is also conceivable that, although our study design did not include data on presence of dyspeptic complaints in the past, a very high optical density goes along with dyspeptic complaints.

our data show that antibodies against Campylobacter pylori can be significantly more frequently detected in patients as compared to blood donors. Although both groups are not fully comparable, this finding remains present after stratification for age and sex, implying that the prevalence of gastritis is or was higher in acutely or chronically ill patients. In an earlier study [22] also a high prevalence of non-ulcer dyspepsia and gastritis in patients admitted in hospital was observed [22]. The explanation for this phenomenon can only be speculative. In a previlous study [23] we found Campylobacter pylori in a large number of antral biopsy specimens of dyspeptic patients with normal antral mucosa, although the microorganisms were present in low numbers. Therefore, we suggested that there is a balance between virulence of Campylobacter pylori and local mucosal defence mechanisms, which when distorted would lead to gastritis. It is tempting to assume that in patients, being in a suboptimal condition, this equilibrium is liable to be distorted, resulting in induction of gastritis.

In keeping with data from others $[11,24,25,26]$ we found an increase in accurrence with rising age, in patients as well as in donors. The rising prevalence of antibodies suggests that the microorganism is acquired later in life. This poses the question of how the bacterium is acquired. In a study of mentally retarded patients [15] the percentage of individuals with antibodies was significantly higher as compared to age matched healthy controls, and correlated with the duration of admittance in the institution. This is suggestive for person to person transmisston.

The most impressive observation from our study is that about one third of a randomly chosen population of blood donors appear to show antibodies against Campylobacter pylori and that an unknown number of these individuals will have active campylobacter associated gastritis There is an ongoing debate in the itterature about the relation between gastritis and dyspeptic 
compladnts $[6,27,28\rceil$. Although our study design did not include data on dyspeptic complaints in the blood donors tested, it may be assumed that in general these healthy individuals do not or did not suffer from dyspeptic complaints to a considerable extend. A definitive answer to this issue awaits further studies evaluating evidence of campylobacter pylori infection in relation to standard computerized questionnaires on dyspeptic complaints. such a study currently is in progress in our department.

\section{REFERENCES}

1 Marsha11 BJ, Warren JR. Unidentified curved bacilli in the stomach of patients with gastritis and peptic ulceration Lancet $1984 ; 1: 1311-4$.

2 Graham DY, Klein PD. Campylobacter pyloridis: the past, the present and speculations about the future. Am J Gastroenterology $1987 ; 82: 283-6$.

3 Price AB, Levi $J$, Dolby JM et.al. Campylobacter pyloridis in peptic ulcer disease: microbiology, pathology and scanning electron microscopy. Gut $1985 ; 26: 1183-8$.

4 Axon ATR. Campylobacter pyloridis: What role in gastritis and peptic ulcer. Br Med J 1986;293:772-3.

5 Rathbone BJ, Wyatt JL, Heatley RV. Campylobacter pyloridis a new factor in peptic ulcer disease. Gut 1986;27:635-41.

6 Kreuning J, Bosman FT, Kuiper G, Wal AM, Lindeman J. GastriC and duodenal mucosa in healthy individuals. J Clin Pathol $1978 ; 31: 69-77$.

7 Siurala M, Isokoscki M, Sipponen P. Gastritis: in Demling (ed.): Klinische gastroenterologie Volume I Thieme Stuttgart 1984:321-37.

8 Perez-Perez GI, Dwarkin BH, Chodos JE, Blaser JM. Campylobacter antibodies in humans. Annals of Internal Medicine $1988 ; 11-7$.

9 Kaldor J, Tee $w$, McCarthy $P$, watson J, Dwyer B. Immune response to Campylobacter pyloridis in patients with peptic ulceration. Lancet $1985 ; 1: 921$.

10 Rathbone BJ, Wyatt JL, Worsley BW et.al. Systemic and local immune responses to gastric Campylobacter pyloridis in non -ulcer dyspepsia. Gut 1986;27:642-7.

11 Jones DM, Eldridge J, Fox AJ, Seht1 P, Whorwell PJ. Antibody to the gastric Campylabacter-like organisms ("Campylobacter pylorids") - clinical correlations and distribution in the normal population. J Med Microbiol 1986;22:57-62.

12 Nowell DG, Johnston BJ, Ali MH, Reed PJ. An enzyme-linked inumuasorbent assay for the serodiagnosis of Campylobacter pylori associated gastritis. Scand J Gastroenterology 1988,23 (supplement 142 ); $53-7$. 
13 Booth $\mathbb{I}$, Holdstock $G$, McBride HM et.al. Clinical importance of Campylobacter pyloridis and associlated serun IgG and IgA antibody responses in patients undergoing upper

gastrointestinal endoscopy. J Clin Pathol 1986;39:215-9.

14 Loffeld RILF, Stabberingh $\mathbf{E}$, van Spreeuwel JP, Flendrig JA, Arends JW. Diagnostic value of an immunoassay to detect anti Campylobacter pylori antibodies in non-ulcer dyspepsia. Lancet $1989 ; 1: 1182-5$.

15 Berkowicz J, Lee $\mathbf{A}$. Person-to-person transmission of Campylobacter pylori. Lancet $1987 ;$ i i; $680-1$.

16 Wyatt $J$, Rathbone BJ, Heatley RV. Local immune response to giastric Campylobacter in non-ulcer dyspepsia. Lancet $1986 ; 1: 1402-3$.

17 von Wulffen $H$, Grote $H_{\text {, Gatermann }} S_{\text {, Loming }} \mathbf{T}$, Berger $\mathbf{B}_{\text {, }}$ Buhl C. Immunoblot analysis of immune response to Campylobacter pylori and its clinical association. I Clin Pathol 1988;41:653-9.

18 Jones DM, Lessels AM, Eldridge J. Campylobacter-1ike organisms on the gastric mucosa: culture, histological, and serological studies. J Clin Pathol 1984;37:1002-6.

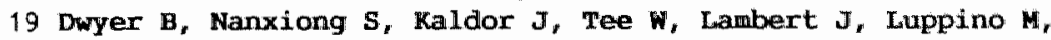
Flannery C. Antibody response to Campylobacter pylori in an ethnic group lacking peptic ulceration. Scand J Infect Dis $1988: 20 ; 69-74$.

20 Rauws EAJ, Langenberg $W$, Houthoff HJ, Zanen HC, Tytgat GNJ . Campylobacter pyloridis associated chronic active antral gastritis. Gastroenterology $1988 ; 94: 33-40$.

21 Vaira D, Holton J, Caines SR et.al. Antibody titers to Campylobacter pylori after treatment for gastritis. Br Med J $1988 ; 297: 397$.

2.2 Talley NJ, McNeil $D$, Hayden $A$, Colreavy $C_{\text {" Piper } D W .}$ Prognosis of chronic unexplained dyspepsia: a prospective study of potential predictor variables in patients with endoscopically diagnosed non-ulcer dyspepsia. Gastroenterology $1987 ; 92: 1060-6$.

23 Loffeld RJLF, Potters HVPJ, Stobberingh E, Arends JW, Flendrig JA, van Spreeuwel JP. Campylobacter associated gastritis in patients with non-ulcer dyspepsia. I Clin pathol. $1988 ; 41: 85-8$.

24 Marshal BJ. McGechie DB, Francis GJ, vtley PJ. Pyloric Campylobacter serology. Lancet 1984;i:281.

25 Graham DY, Klein PD, Opekun AR. Epidemiology of Campylobacter pyloridis infection. Gastroenterology $1987 ; 92: 1411$.

26 Eldriage $J$, Jones DW. Longitudinal study of the incidence of antibody to Campylobacter pylori in schoolchildren. Proceedings First Meeting of the European Campylobacter pylori study group Ed: F Megraud, H Lamouliatte Bordeaux 1988.

27 Siurala M, Varis K. Gastritis In: Wircus, AN Smith eds. Scientific foundation of gastroenterology Williams Heinemann London 1980:357-69.

28 Joffe SN, Rao SS. Symptoms of gastritis. Scand J Gastroenterol. $1982 ; 17$ (supplement) :62-5. 
RETROSPECTIVE STUDY OF CAMPYLOBACTER-LIKB ORGANISMS IN PATIENTS UNDERGOING PARTIAL GASTRECTOMY

R.J.L.F.Loffeld*

B.C.A.J.Loffeld**

J.W.Arends**

J.A.Flendrig*

J.P. van Spreeuwel*

Departments of Internal Medicine* and Pathology**, University Hospital Maastricht

Published in Journal of Clinical Pathology 1988;41:1313-1315 (with permission of the publisher). 
One hundred and five stoma biopsy specimens and 108 corpus biopsy specimens from 108 patients who had undergone a partial. gastrectomy because of peptic ulcer disease were examined retrospectively for the presence of Campylobacter-like organisms and gastritis. In the corpus biopsy specimens campylobacter associated gastritis was found in 55 (718) of the cases and in 42 (48.) of the stoma biopsy specimens. It is concluded that Campy lobacter-1ike organism have a role in gastritis after partial gastrectomy, although this role is more prominent in the corpus region. The role of Campylobacter pylori in peptic ulcer disease is not clinically important.

\section{INTRODUCTION}

In 1984 Marshad 1 and warren first drew attention to the association between the presence of curved bacilli (Campylobacter pylori) and type $B$ (antral) gastritis as well as peptic ulcers [1]. Since then this association has been amply confirmed [2-7], but a debate has been going on as to the clinical importance of the observation. Several questions remain unanswered. Does Campylobacter pylori have a pathogenetic role in gastritis and peptic ulcer disease or does it merely represent an epiphenomenon? Does Campylobacter associated gastritis predispose to the development of gastric ulcers?

One way to address the second question is to study the fate of Campylobacter pylori in gastric mucosa after effective treatment for ulcers. If Campylobacter pylori were of pathogenetic importance in the pathogenesis of peptic ulcers through the induction of gastritis a pronounced decline in or absence of the microorganism would be expected under these circumstances.

In the era before H2-receptor blocking drugs partial gastrectomy was regarded as the most effective treatment for peptic ulcex disease. Relapse of ulcers and the finding of gastritis in the gastric remnant was attributed to the reflux of bile. There are some data on the effect of treatment for 
gastritis on Campylobacter pylori, and they show a decrease in Campylobacter colonization and a decrease in gastritis score [8]. The eradication of Campylobacter pylori leads to a significant decrease in the relapse rate of duodenal ulcers [9]. Hittle is known, however, about the fate of Campylabacter pylori after gastric surgery carried out because of peptic ulcer disease.

o'connor et al. looked for Campylobacter-like organisms in patients with a partial gastrectomy [10] and found that most were not colonised. A transition from Campylobacter associated gastritis to reflux gastritis in the gastric remnant was suggested by these authors. Their material, however, consisted only of biopsy specimens taken from within $5 \mathrm{~cm}$ of the stoma and therefore the question as to whether Campylobacter pylori has a role in gastritis after partial gastric resection could not be properly addressed. In this paper we report on the presence of campylobacter-like organisms in the stoma region as well as in the fundus of the gastric remnant.

\section{MATERIAL AND METHODS}

Biopsy specimens from 108 patients who had undergone a partial gastrectomy (either the Billroth I or Billroth II type) because of peptic ulcer disease were studied. The patients comprised of 92 men (mean age 63 years, range 35-86) and 16 women (mean age 60 years, range 30-75). All patients were seen in our endoscopy department during regular follow-up. Twenty nine $(24$ men and five women) had a partial gastrectomy of Billroth I type and 79 ( 68 men and 11 women) had a Billroth II operation. The time between the operation and the examination of the follow-up biopsy specimens ranged from two to 46 years.

Endoscopy was performed with the olympus GIF Q or GIE K gastroscope, and biopsy specimens were taken from the stoma and from the corpus (gastric remnant), about $5 \mathrm{~cm}$ below the cardia, or halfway between the cardia and the stoma if the gastric remnant was smal1. All specimens were fixed in Bouin's solution. Sections were recut and stained with Haematoxylin and Eosin for histological grading of gastritis according to whitehead [11] and 
with a noditied Giemsa stain $[12,13]$ for the histological detection of campylobacter-1ike organisms. Sections were regarded as positive for Campylobacter-1ike organisms if the typical curved bacilil were seen in the gastric mucus overlying the ept thelium.

The presence of Campylobacter-1ike organisus was graded on a semiquantitative scale; grade 0 = no bacteria detected; grade $1=$ sporadic bacteria found; grade 2 = many bacteria found in almost all high power flelds $(400 \mathrm{x})$; and grade 3 = clusters of bacteria found in all high power fields.

statistical analysis was performed by the chi-square test.

\section{RESULTS}

Gastritis was present in 87 ( 83 \%) of 105 stomal biopsy specimens: (Whitehead grade 2 or 3 ). Of these, 42 (48\%) were positive for Campylobacter-1ike organisus (grade $1 / n=15$, grade $2 / n=13$, grade $3 / n=14)$, and $45(52 \%)$ were negative for Campylobacter-like organisms.

Eighteen biopsy specimens showed no signs of gastritis. Of these, 15 (B3\%) were negative for Campylobacter-like organisms, three (17\%) were positive for Campylobacter-1ike organism (grade $1 / n=1$, grade $2 / n=2)$. Campylobacter-like organisms were detected in 45 of 105 (43\%) stomal biopsy specimens.

of 108 corpus biopsy specimens, 77 (71\%) were positive for gastritis (Whitehead grades 2 and 3 ), 55 (718) were positive for Campylobactex-1ike organisms lgrade $1 / n=18$, grade $2 / n=13$, grade $3 / n=24)$, and 22 (27\%) were negative for Campylobacter-1ike organisms. Thirty one specimens had no signs of gastritis, 21 (68) were negative for Campylobacter-like organisms, and 10 (328) were positive for Campylobacter-like organisms (grade $1 / \mathrm{n}=6$, grade $2 / \mathrm{n}=2$, grade $3 / \mathrm{n}=2)$. Campylobacter-like organisms were detected in 65 of $108(60 \%)$ corpus biopsy specimens compared with 45 of 105 (438) stomal biopsy specimens $(p=0.01$ ) (tables 1 and 2 ). 


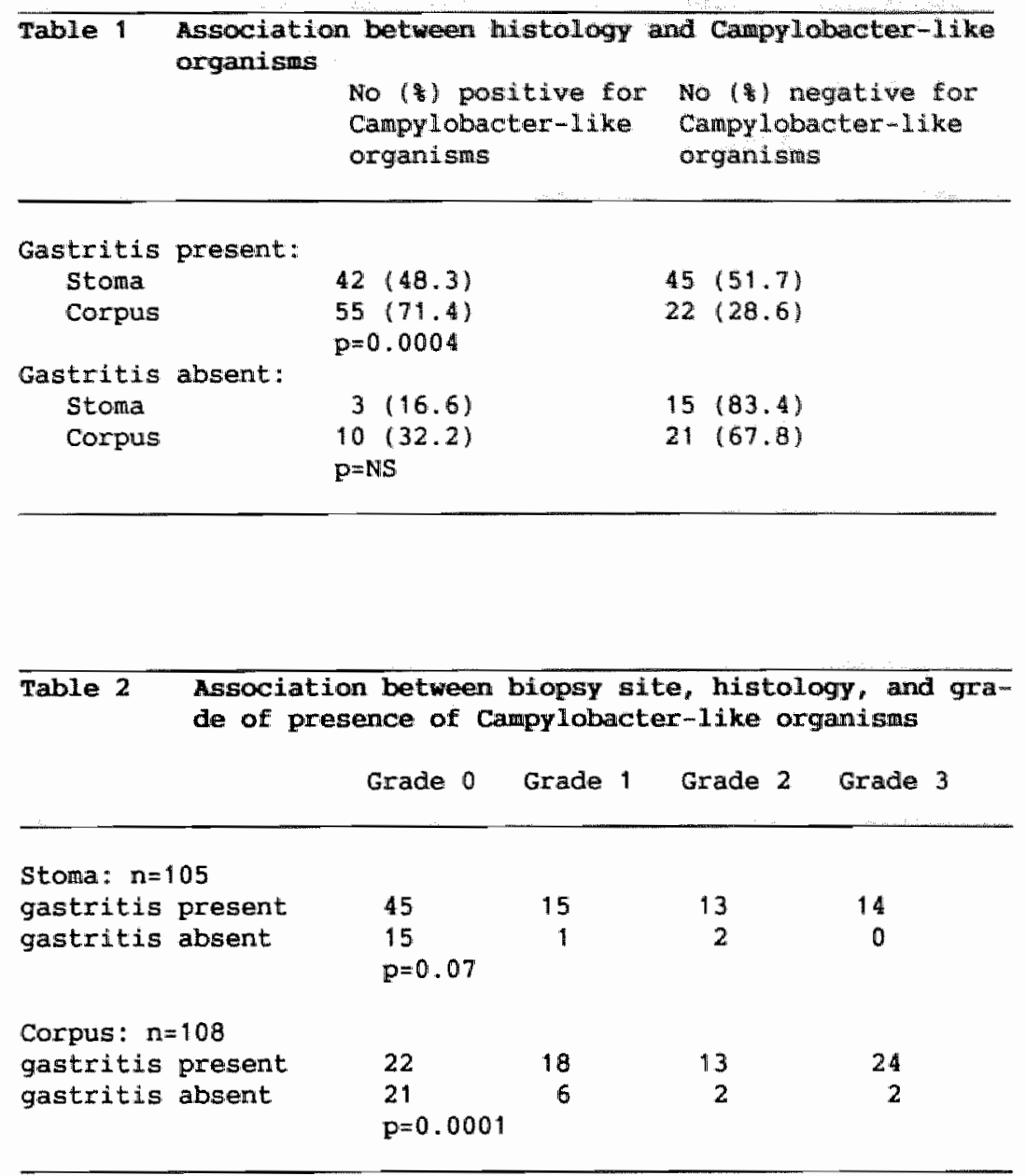

Less than 10 years after surgery, Campylobacter-1ike organisms were found in 12 of 17 (70) corpus blopsy specimens. This percentage did not change significantly the longer the interval after the operation, with 53 of 91 (60\%) remaining positive for Campylobacter-like organisms. In stomal bilopsy specimens, however, a change occurred when the interval from operation was greater than 10 years. Before 10 years, nine of 15 (60\%) of stomal biopsy specimens were positive for Campylobacterlike organisms, but after 10 years this fell to 36 of 90 (40\%) $(p=0.0007)$. 


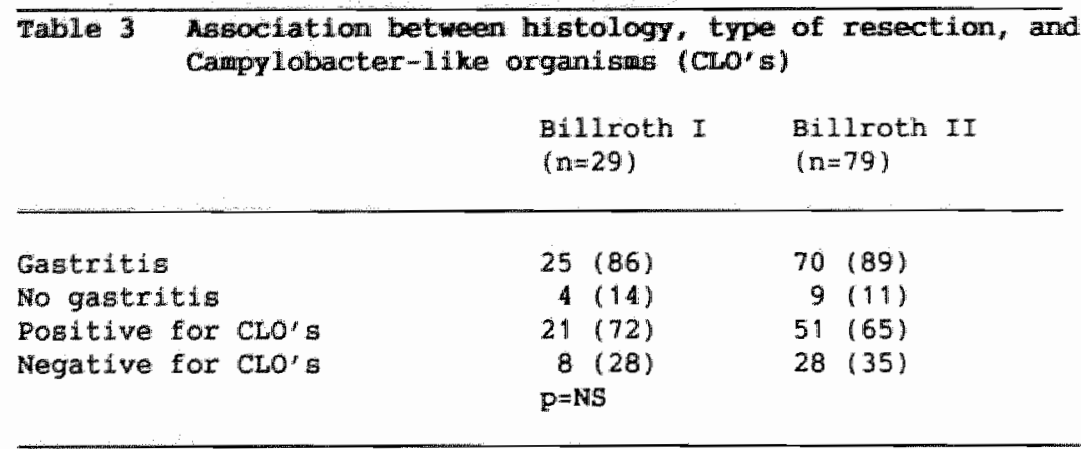

Table 3 shows that there was no difference between the type of operation and presence of campylobacter-like organisms or gastritis.

In the absence of gastritis in the corpus or stomal biopsy specimens we found either normal histology $(n=26)$, atypia $(n=10)$, intestinal metaplasia $(n=16)$, or atrophy $(n=10)$. Atypia and intestinal metaplasia were almost entirely confined to the specimens negative for Campylobacter-like organisms, atrophy and normal histology were found in specimens either positive or negative for Campylobacter-like organisms.

\section{DISCUSSION}

The effect of gastric surgery (Billroth I and II operation) on Campylobactex colonization has been studied in two reports. The authors found evidence of Campylobacter-1ike arganisms in 26\% [13] and in 34\% [15], respectively, and concluded that campylobacter pylori did not have a rolle in post-gastrectomy gastritis. After measurement of bile contents in the gastric remnant they concluded that Campylobacter pylori was eradicated by bile reflux and that reflux gastritis was induced. Only biopsy specimens taken from within $5 \mathrm{~cm}$ of the stoma were studied. In keeping with these data we observed a prevalence of $43 \%$ for campylobacter-1ike organisms in the stomal biopsy specimens which rose to $60 \%$ in the 
corpus biopsy specimens. Our data also indicate that in the corpus the presence of Campylobacter-like organisms seemed to be substantially associated with gastritis; 71 of the bilopsy specimens showing gastritis were positive for Campylobacter-1ike organisms. By contrast stomal gastritis was less often associated with Campylobacter-1ike organisms as more than half of the specimens with gastritis were negative for Campylobacter-1ike organisms. This suggests that the disruption of the mucosal barrier by bile reflux and subsequent development of a microenvironment unfavorable to colonization by Campylobacter pylori"will probably be responsible for the gastritis. In cases without gastritis there was no significant difference in the presence of Campylobacter-like organisms between corpus and stoma blopsy specimens.

These observations suggest that Campylobacter associated glastritis persists in the corpus region after partial. gastrectomy. The difference in prevalence of campylobacter-like organisms between the stoma and the corpus biopsy specimens could not be explained by differences in the prevalence of intestinal metaplasia.

After surgery certain histological features are correlated with the reflux of bile in the stomach [14]. Atypla is often considered to be a sign of regeneration because of bile reflux. In the absence of gastritis we found atypia in the group negative for Campylobacter-like organisms, which suggests bile reflux is responsible for the absence of Campylobacter pylori. Cases of intestinal metaplasia were found in the group negative for Campylobacter-like organisms: Campylobacter pylori is thought to have a special affinity for the gastric mucosa.

The observation of $0^{\prime}$ Connor et al. that the presence of Campylobacter-like organisms was influenced by the length of interval from operation [10] could only partly be confirmed by our data. The prevalence of Campylobacter-11ke organisms aftex a short interval was higher, but this was only true for the stomal biopsy specimens, no statistical difference being found in corpus biopsy specimens compared after long or short follow-up. There was no difference in prevalence of Campylobacter-like organisms between Billroth I and II resection specimens. 
In conclusion we detected a Campylobacter associated gastritis in a high number of patients after gastric surgery for peptic ulcer disease which suggests that this organism still has a role in gastritis in the partial resected stomach, although this role is more prominent in the gastric remant than in the stoma region. As apparently the therapeutic effect of partial gastrectomy on gastric ulcers cannot be explained by a decrease of Campylobacter associated gastritis. This argues against the theory that Campylobacter pylori is a single factor in the pathogenesis of peptic ulcer disease. The exact role of Campylobacter pylori in gastritis, however, remains to be elucidated.

\section{REFERENCES}

1 Marshall BJ, Warren JR. Unidentifled curved bacilli in the stomach of patients with gastritis and peptic ulceration. Lancet $1984 ; i: 1311-14$.

2 Jones DM, Lessels AM, Eldridge J. Campylobacter-1ike organism on the gastric mucosa: culture, histological and serological studies.J Clin Pathol 1984;37:1002-6.

3 Axon ATR. Campylobacter pyloridis: what role in gastritis and peptic ulcer? Br Med $J 1986 ; 293: 772$.

4 Rathbone BJ, wyatt JL, Heatley RV. Campylobacter pyloridis: a new factor in peptic ulcer disease. Gut 1986;27:635-41.

5 Loffeld RJLF, Potters HVPJ, Arends JW, Stobberingh $\mathbf{E}$, Flendrig JA, van Spreeuwel JP. Canpylobacter-associated gastritis in patients with non-ulcer dyspepsia. J Clin Pathol $1988 ; 41: 85-88$.

6 Rathbone BJ, Wyatt $J_{\text {, Worsley }} \mathrm{Bm}$ et al. Systemic and local immune responses to gastric Campylobacter pyloridis in non -ulcer dyspepsia. Gut 1986;27:642-7.

7 Booth $L$, Holdstock $G$, McBride il al. Clinical importance of Campylobacter pyloridis and associated IgA and IgG antibody responses in patients undergoing upper gastrointestinal endoscopy. I Clin pathol 1986;39:215-19.

8 McNulty CAM, Ceanty JC, Crump B et al. Campylobacter pyloridis and associated gastritis: investigator blind placebo controlled trial of bismuth salicylate and erythromycine ethyl succinate. Br Med J 1986;293:645-9.

9 Coghlan JG, Humphries H. Dooley $\mathrm{C}$ et al. Campylobacter pylori and the recurrence of duodenal ulcers, a 12 month follow-up study. Lancet $1987 ; 1: 1109-11$.

10 O"Connor HJ, Wyatt $\pi$, Ward $\mathrm{DC}$ et al. Effect of duodenal ulcer surgery and enterogastric reflux on Campylobacter pyloridis. Lancet $1986 ;$ i i : $1178-81$. 
11 Whitehead $\mathbf{R}$. Mucosal biopsy of the gastrointestinal tract. In: Bennington JL ed. Major problems in pathology, vol III. 2nd ed. Philadelphia: ws Saunders, 1979.

12 Potters HVPJ, Loffeld RLJF, Stobberingh $\mathbf{E}$, van Spreeuwel JP, Arends $\mathrm{J}$. Rapid staining of Campylobacter pyloridis. Histopathology $1987 ; 11: 1233$.

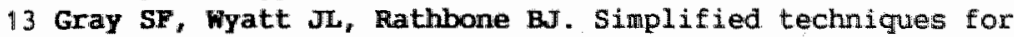
identifying Campylobacter pyloridis. J Clin Pathol $1986 ; 39: 1279-80$.

14 Dixon kF, $O^{\prime}$ Connor HJ, Axon ATR, King RFGJ, Johnston D. Reflux gastritis-distinct histological entity. I Clin Pathol $1986 ; 39: 524-30$. 
CAMPYLOBACTER ASSOCIATED GASTRTTIS IN PATIENTS WITH NON-ULCER DYSPEPSIA: A DOUBLE BLIND PLACEBO CONTROLLED TRIAL WITH COLLOIDAL BISMUTH SUBCITRATE

R.J.L.F.Loffeld*, H.V.P.J.Potters**,

E. Stobberingh***, J.A. Flendrig*, J.P. van Spreeuwel*, J.W. Arends** Departments of Internal Medicine*, Pathology* and Microbiology** University Hospital Maastricht PO BOX $19186201 \mathrm{BX}$ Maastricht

Accepted for publication in Gut. 
Fifty consecutive patients with non-ulcer dyspepsia and a Campylobacter associated gastritis (CAG) were randomly assigned to treatment with collaidal bismuth subcitrate (CBS) $240 \mathrm{mg}$ twice dafly or placebo, according to a double blind study design. After the blind treatment an "open" treatment with CBS was started in both groups. Twenty six patients who were treated with CBS showed a signiflcant reduction in colonization with Campylobacter pylori and a significant improvement in the Whitehead gastritis score. No significant changes were recorded in twenty four patients who were treated with placebo. After an additional course of CBS no further improvement in gastritis score was noted, but there was a further reduction in Campylobacter colonization. Colloidal bismuth subcitrate did not greatly alter subjective complaints. Subjective complaints were improved in both treatment groups except for nausea and meteorism that improved more in the CBS treated patients. This finding again questions the clinical significance of gastritis and also casts doubt on the clinical relevance of therapeutical measures aimed at eradication of Campylobacter pylori.

\section{INTRODUCTION}

Reports on the presence of spiral bacteria in the human stomach have appeared sporadically over the last century $[1,2,3]$. Since the work of Marshall and warren, however, the possible pathogenetic significance of these organisms on type $B$ (antral) gastritis was appreciated [4], and was confirmed by other investigators $[5,6,7,8]$. Campylobacter pylori is found in patients. with gastritis in 98\%, in patients with gastric ulcer in $80 \%$ and in patients with duodenal ulcer in 908 of the cases. In patients with dyspeptic symptoms but normal gastric histology campylobacter pylori has also been seen overlying the mucosa, but only in sma11 numbers [8].

About one third of patients referred for upper gastrointestinal endoscopy because of upper abdominal complaints appear not 
to suffer from peptic ulcers, oesophagitis, active duodenltis or gastric carcinoma and therefore by definition suffer from socalled non-ulcer dyspepsia. These patients constitute a heterogenous group for which at present no effective therapy is available. It has been shown that more than half of the patients with non-ulcer dyspepsia histologically show an active chronic gastritis [8,9]. It has been suggested that a Campylobacter associated gastritis (CAG) may actually cause dyspeptic complaints [10].

The question if Campylobacter pylori is of pathogenetic significance in gastritis and non-ulcer dyspepsia could be answered by using drugs that are active against campylobacter pylorì.

There are several in vitro studies on the susceptibility of Campylobacter pylori for different drugs. Campylobacter pylori appeared to be susceptible for many antibiotics such as ampicillin, erythromycin, gentamicin and ciprofloxacin, while being insensitive to sucralfate and cimetidine in normal pharmacological dosages. In addition Campylobacter pylori appears to be sensitive to bismuth preparations, like colloidal bismuth subcitrate (CBS) in low dosages $[11,12,13,14,15]$.

We therefore decided to carry out a prospective double blind placebo controlled trial in order to evaluate the effect of CBS on Campylobacter associated gastritis in patients with non-ulcer dyspepsia.

\section{MATERTAL AND METHODS}

One hundred and forty five consecutive patients with upper abdominal complaints referred to the endoscopy department for upper gastrointestinal endoscopy were studied prospectively for the presence of Campylobacter associated gastritis. Patients with gastric or duodenal ulcer, refluxoesophagitis, active duodenitis, gastrectomy and carcinomas as well as patients using non-sterou dal anti inflammatory drugs or antibiotics were excluded. In view of a possible teratogenic effect and accumulation of the drug, pregnant women and patients with renal insufficiency were also 
excluded from participation [16].

Eighty six patients (59) showed gastritis histologically with presence of Campylobacter pylori proven by histological examination and/or positive culture. Of these 57 (668) gave informed consent and entered the study.

Whe 57 patients comprised of 30 men and 27 women, seven patients were excluded for the following reasons: during revision two patients appeared to have normal gastric histology at entry of the study, five patients were not compliant with therapy, three taking CBS and two took placebo.

Fifty patients ( 27 men, 23 women, mean age 48 years, range 18-73) concluded the blind treatment, 34 patients gave informed consent for the open treatment.

All patients were treated blindly with colloidal bismuth subcitrate (CBS, De-Nol) $240 \mathrm{mg}$ b.i.d. or placebo during 28 days, subsequently they received an open treatment with CBS $240 \mathrm{mg}$ b.1.d. during another 28 days. All preparations were provided by Gist Brocades Farmaca.

Patients were evaluated before treatment and within 24-72 hours after discontinuation of the blind as well as the open treatment. Evaluation consisted of a standard history using a questionnaire including present complaints, smoking habits, alcohol consumption, medication and family history for upper abdominal complaints.

Al1 patients were subjected to upper gastrointestinal endoscopy after being starved for at least eight hours. Endoscopy was performed, without local anaesthetic, using an Olympus GIF $Q$ gastroscope and biopsies were taken from the gastric antrum for culture $(1 x)$ and histological examination $(3 x)$, and from the gastric corpus for histological examination (1x).

The questionnaire was repeated and changes of complaints were recorded. Besides overall assessment (unchanged, improved, worsened or disappeared) five dyspeptic symptoms (pain, heartburn, nausea, burping and meteorism) were scored as present, absent, diminished or increased.

Examination of the containers returned by the patients indicated compliance with treatment. 
The study was approved by the medical ethics committee of the University Hospital of Maastricht.

The chi-square test was used for statistical analysis.

\section{Histology}

The biopsies were fixed in Bouin's fixative. Sections were stained with Haematoxylin and Eosin for histologlcal grading of gastritis according to a modified whitehead classification [17]. Grade 0: gastric histology within normal limits; grade 1 : slight increase of mononuclear cells but within normal limits; grade 2 * increase of mononuclear cells, polymorphonucleax cells present; grade 3: increase in mononuclear and polymorphonuclear cells, polymorphonuclear cells also invading the epithelium.

Biopsies demonstrating features consistent with whitehead grade 2 and 3 were considered to be showing gastritis, whereas Whitehead grade 0 and 1 were regarded as being within normal histological limits. Change of histology from whitehead grade 3 to grade 2 and from grade 3 or 2 to grade 1 or 0 was considered as improvement or cure of gastritis respectively.

Sections for the histological detection of Campylobacterlike organisms (CLO's) were stained with a modified Giemsa stain [18]. For semiquantitative presence of cLo the following criteria were employed: grade 0 : no bacteria detected; grade 1: sporadic bacteria observed; grade 2: many bacteria seen in most microscopic fields at high power magnification $(400 \mathrm{x})$ and grade 3: clusters of microorganisms found in the superficial mucus layer in all fields examined.

All biopsies were reviewed before final analysis. The biopsies were studied by two pathologists without prior knowledge of clinical data.

\section{Microbiology}

One biopsy was put in sterile saline $0.9 \%$ and then transported to the microbiological department for culture. The biopsies were incubated on a blood agar medium of $6 \%$ sheep blood under micro-aerophilic conditions $\left(\mathrm{CO}_{2} 10 \%, \mathrm{O}_{2} 5 \%\right)$, during five to seven days at 37 degrees Celsius. The culture was regarded as positive when typical colonies of campylobacter pylori were seen. 
If culture still did not show growth after 7 days it was regarded regative. If culture was positive and the histology failed to show CLo's, the histological grading for presence of Campylobacter pylori. was considered to be grade 1 [8].

\section{RESULIS}

The blind treatment was concluded by 50 patients, 26 recelved CBS 113 men, mean age 47 years, range $32-67$ and 13 women, mean age 48 years, range 18-70) and 24 placebo (14 men, mean age 38 years, range $22-73$ and 10 women, mean age 57 years, range 38-65). Eighteen of the CBS group and 17 patients of the placebo group entered the additional "open" treatment. The others refused further therapy because of sufficient subjective improvement or because of fear for repeated upper gastrointestinal endoscopy.

At entry of the study there was no significant difference with regard to sex, age, subjective complaints, degree of gastritis according to whitehead or semiquantitative grading of Campylobacter pylori presence between the CBS and the placebo group (Tables 1, 2, and 3).

Table 1 Complaints at start of the trial

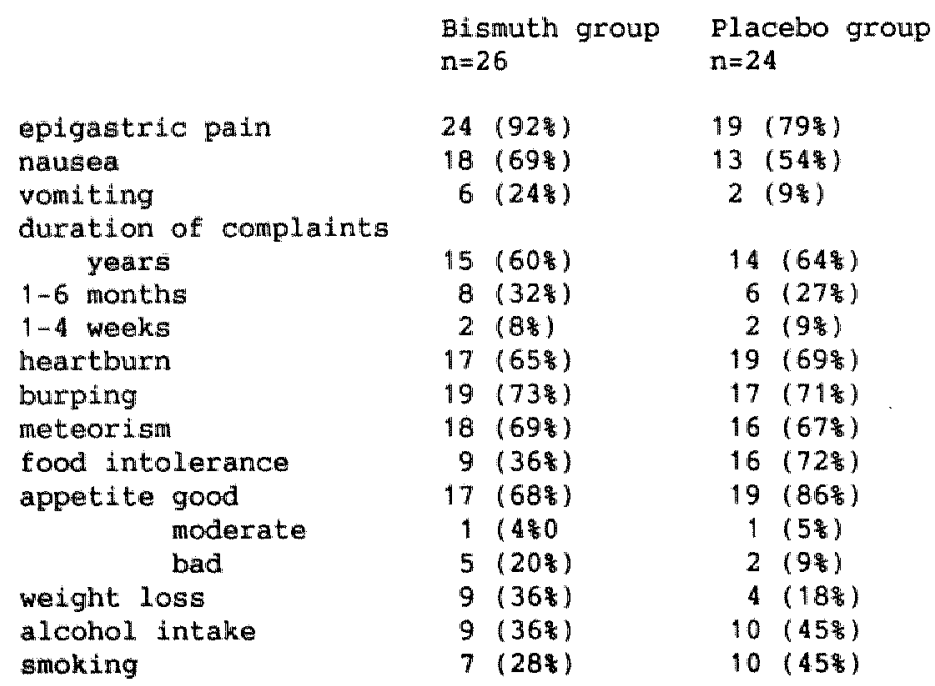




\section{CBS and gastritis}

In Table 2 the correlation between CBS or placebo administration and gastritis is shown. As can be seen from this table the percentage of patients with grade 3 gastritis was reduced from 88 to 38 after 28 days of CBS, whereas no further reduction was obtained after 56 days. In contrast after 28 days of placebo administration no effect on the percentage of patients with grade 3 gastritis was observed. After 28 days of cBs therapy, however, a significant reduction of grade 3 gastritis was noted. Figure 1 shows the changes in histology of the individual patients. Normalisation of gastric histology occurred in nine (35\%) patients of the CBS group and in one (4\%) patient of the placebo group $(p=0.02)$

\section{CBS}

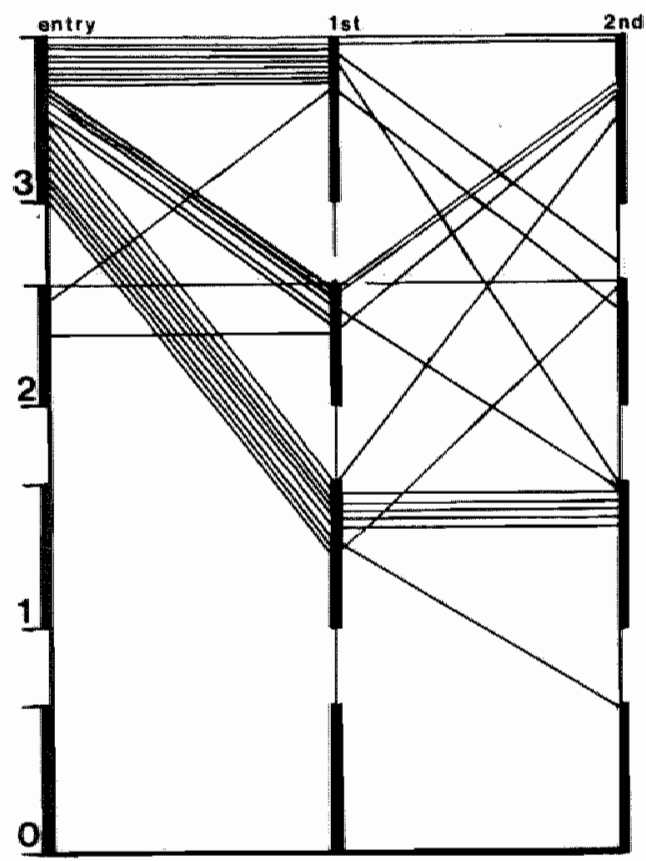

\section{PLACEBO}

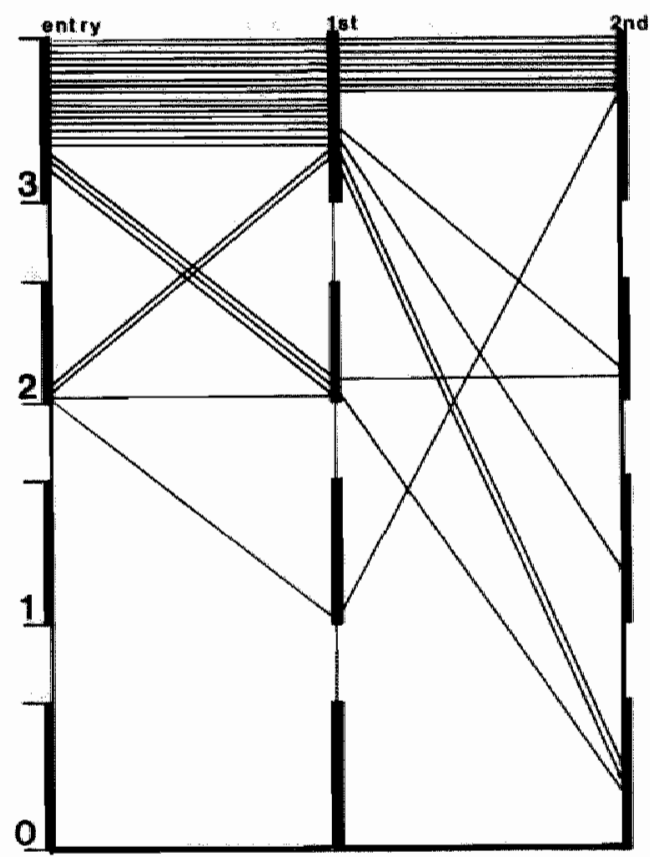

Figure 1: Changes in gastritis score after CBS and placebo treatment. 1st means after CBS and placebo treatment respectively, 2nd means after open treatment with CBS. 


\begin{tabular}{|c|c|c|c|}
\hline Table 2 & $\begin{array}{l}\text { Gastritis score } \\
n=26\end{array}$ & $\begin{array}{l}\text { according to } \\
\mathrm{n}=26\end{array}$ & $\begin{array}{r}\text { Whitehead } \\
\qquad=18\end{array}$ \\
\hline CBS group & start trial & 28 days CBS & 56 days CBS \\
\hline grade 3 : & $23(885)$ & $10(398)$ & $6(33 \%)$ \\
\hline grade 2: & $3(12 z)$ & $7(285)$ & $4(225)$ \\
\hline grade 1: & 0 & $9(33)$ & 7 (39\%) \\
\hline grade 0 : & 0 & 0 & $1(6 \%)$ \\
\hline placebo group & $n=24$ & $n=24$ & $\pi=16$ \\
\hline grade $3:$ & $20\left(83 \frac{1}{6}\right)$ & $19(798)$ & $10(658)$ \\
\hline grade 2 : & 4 (165) & $4(178)$ & $2\left(12 \frac{1}{8}\right)$ \\
\hline grade $1:$ & 0 & $1\left(4 \frac{5}{5}\right)$ & $1\left(6 \frac{5}{5}\right)$ \\
\hline \multirow[t]{2}{*}{ grade 0: } & 0 & 0 & $3(17 \%)$ \\
\hline & $p=n s$ & $p=0.0007$ & $\mathrm{p}=\mathrm{ns}$ \\
\hline
\end{tabular}

\section{CBS and Campylobacter pylori presence}

Table 3 shows the influence of CBS or placebo on the presence of Campylobacter pylori after 28 days and 56 days of therapy respectively. The percentages of patients with grade 3 presence was reduced from 38 at start of the therapy to 12 after 28 days of CBS and a further reduction was obtained after 56 days of therapy. No such effect was found in patients given placebo treatment. Grade 3 presence was significantly reduced after the "open" treatment course in these patients. Figure 2 shows the changes of the individual patients.

In one patient of the CBS group endoscopy, after CBS, revealed a small gastric ulcer located at the angulus, this patient did not show any improvement of gastritis score. After the additional course of CBS it was healed. One patient of the placebo group showed a duodenal ulcer after 28 days of placebo therapy that healed after cBS. 
CBS

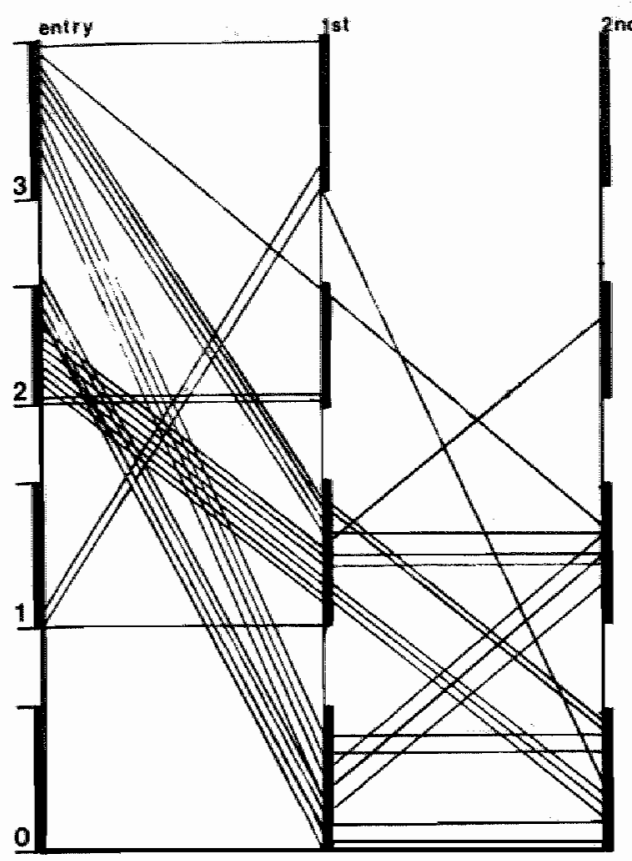

\section{PLACEBO}

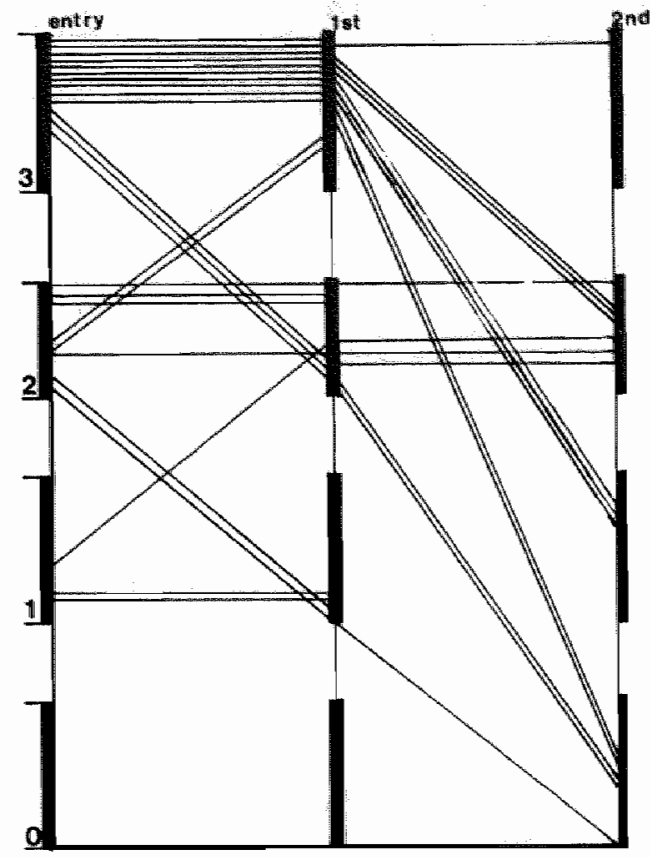

Figure 2: Changes in CLO presence between the CBS group and the placebo group.

Table 3 Semiquantitative presence of Campylobacter pylori

\begin{tabular}{|c|c|c|c|}
\hline & & & \\
\hline & $n=26$ & $m=26$ & $n=18$ \\
\hline CBS group & start trial & 28 days bismuth & 56 days bismuth \\
\hline grade $3:$ & $10(38: 9)$ & $3(12)$ & 0 \\
\hline grade 2 : & $13(5096)$ & $3(12)$ & $1(58)$ \\
\hline grade 1: & $3(128)$ & $12(46)$ & $7(39)$ \\
\hline grade 0 : & 0 & $8(308)$ & $10(569)$ \\
\hline placebo group & $n=24$ & $n=24$ & $n=16$ \\
\hline grade $3:$ & $13(54 \%)$ & $12(508)$ & $1(66)$ \\
\hline Grade 2: & $8(339)$ & $8(338)$ & $7(44)$ \\
\hline grade 1: & $3(138)$ & $4(178)$ & $3(19$ ) \\
\hline grade 0 : & 0 & 0 & $5(31)$ \\
\hline & $\mathrm{p}=\mathrm{ns}$ & $\mathrm{p}=0.00001$ & $p=0.01$ \\
\hline
\end{tabular}




\section{CBS and symptoms}

As shown in Table 4 overall assessment of subjective changes of complaints revealed improvement in half of the patients given CBS, 30 recorded no change at all, 16 became free of complaints and one patlent noted worsening of his complaints due to the peptic ulcer. Seventy one percent of the patients given placebo recorded improvement, whereas none became free of complaints. The remainder noted no change. There appeared to be no significant difference in overall assessment between both groups. There was no significant difference between the five symptoms that were recorded separately in both groups. AlI symptoms showed the same improvement (Table 5). Figure 3 , however, shows that the percentual improvement of nausea and meteorism in the CBS group was better.

$\begin{array}{ll}\text { Table } 4 & \text { Subjective changes of complaints } \\ \text { CBS group } & 28 \text { days CBS } \\ \text { improvement } & 13(50 \%) \\ \text { worsening } & 1(48) \\ \text { no change } & 8(30 \%) \\ \text { no complaints } & 4(169) \\ \text { placebo group } & 28 \text { days placebo } \\ \text { improvement } & 17(71 \%) \\ \text { worsening } & 0 \\ \text { no change } & 7(29 \%) \quad \text { p=ns } \\ \text { no complaints } & 0\end{array}$

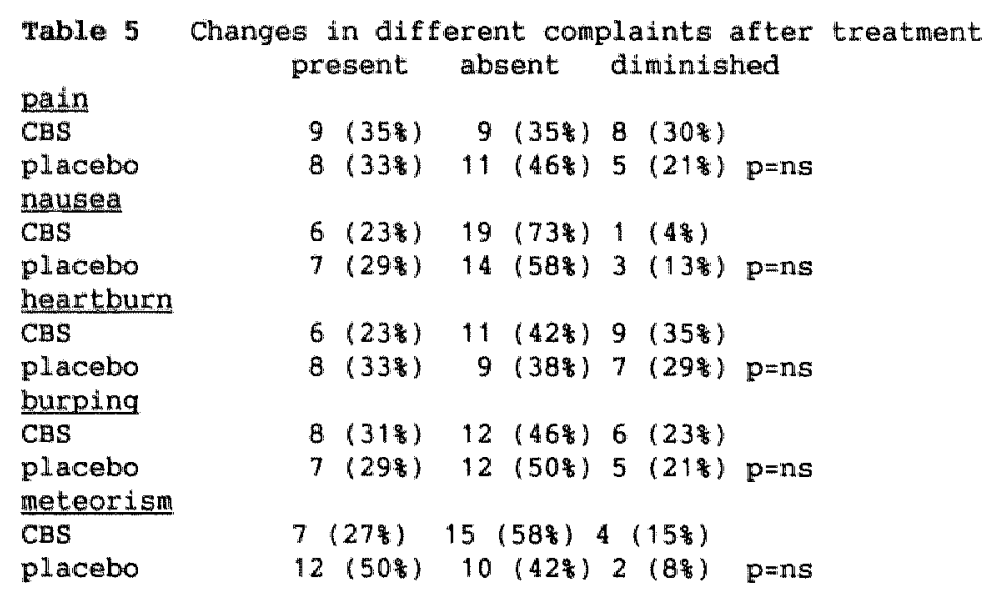




$\begin{array}{ll}\text { present } & \text { b:cbs } \\ \text { diminished } & \text { p:Placebo } \\ \text { Qabsent } & \end{array}$

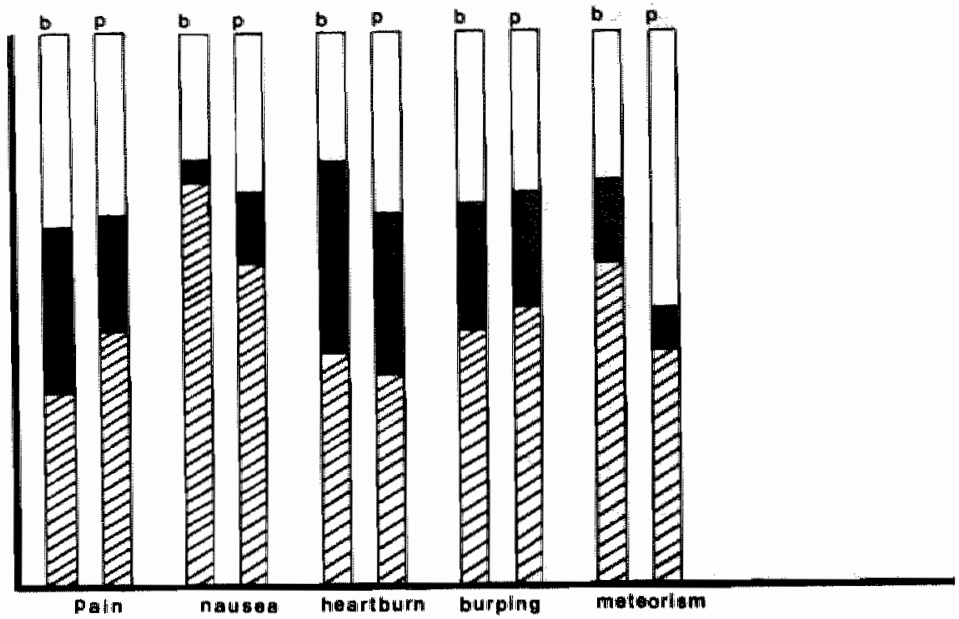

Figure 3: Percentual changes in complaints after treatment in the CBS and the placebo group.

\section{DISCUSSION}

In the literature there are several reports on the effect of bismuth on gastritis and Campylobacter pylori in patients with non-ulcer dyspepsia $[19,20,21,22,23,24]$. The results of these studies show that there is a resolution of gastritis after suppression or eradication of Campylobacter pylori. The majority of these studies, however, failed to provide exact information on inclusion criteria, standardisation of gastritis and Campylobacter pylori scores.

In addition the best available data on the treatment of Campylobacter associated gastritis, especially with bismuth, have been based on non controlled trials [25].

Bismuth salts have two effects: they are bactericidal for 
Campylobacter pylori and they can protect the gastric mucosa against erosive properties of alcohol and aspirin. Bismuth may protect the mucosa from gastric acid with subsequent resolution of gastrits with alteration of the gastric milieu, which is unfavorable for Campylobacter prlori. Sucralfate has no bactericidal effects on Campylobacter pylori, and it has no beneficial effect on histologically confirmed gastritis [26]. This suggests that it is the antimicrobial activity of bismuth that is important. Campylobacter pylori produces a protease that undermines the integrity of the mucus layer. Therefore because of its bactericidal effect bismuth may have an indirect favorable effect on gastric mucosa [27].

McNulty et al. reported on a double blind study of bismuth salicylate $[28], 77.88$ of their patients recelving bismuth were cleared of Campylobacter pylori after treatment. This clearance was accompanied with a significant improvement of gastritis score.

The results of our study, also show that CBS effectively reduces Campylobacter colonization of gastric mucosa and significantly improves signs of gastritis. Complete disappearance of the microorganism, however, only occurred in a small number of patients, which possibly explains the high percentage of recurrence reported in the literature $\llbracket 29,30 \rrbracket$. In addition we showed a positive influence of administration of CBS on subjective complaints which, however, largely appeared to be due to a placebo effect.

Two pertinent aspects of our observations deserve special consideration. First at day 28 a parallelism in reduction of Campylobacter pylori presence and gastritis score was seen in the CBs treated patients, suggestive of a causative role of Campylobacter pylor1. Subsequent administration of CBS, however, only resulted in further clearance of Campylobacter pylori and no further improvement of gastritis scores was noted. It is conceivable that this discrepancy is the result of a longer period of time necessary for resolution of all signs of inflammation. It would, therefore, be interesting to evaluate gastric biopsies for the presence of gastritis some time after cessation of CBS treatment. On the other hand, the findings can be satisfactorily 
explained on the basis of the assumption that bacterial clearance and improvement of gastritis basically are two independent processes. In this context it could be hypothesilued that Campylobacter associated gastritis is caused by multiple aetiologio agents amongst which is Campylobacter pylori. Reduction of the impetus of Campylobacter pylori would then eliminate its contribution in the inflammatory response leaving the influence of other inflammatory impeti unaffected. Finally it may be possible that the remaining gastritis is the result of a small number of Campylobacter pylori still present after therapy, implying that more effective therapy could cure all signs of gastritis.

In keeping with the findings in the literature we found no significant effect of placebo therapy on gastritis nox on Campylobacter pylori colonization.

A second point of considerable concern raised by our data is that there appeared to be no difference in improvement of subjective complaints between CBS and placebo treated patients. There are several conflicting studies on the effect of bismuth on complaints in patients with non-ulcer dyspepsia and Campylobacter associated gastritis. Some authors observed significant reduction. in several complaints $[20,23,24,31]$, whereas others found no difference between Campylobacter pylori patients treated with bismuth or placebo [28]. As it is known from the literature that asymptomatic persons may show signs of gastritis in their biopsies [32], we feel that the discrepancy we observed between improvement of Campylobacter pylori presence and gastritis scores effected by CBS on the one hand, and lack of a difference of CBS on subjective complaints as compared with controls on the other hand, is probably due to a non existent direct relation between gastritis and dyspepsia.

We conclude that CBS appears to be effective in the elimination of Campylobacter pylori, diminishes the degree of gastritis but has a positive effect on dyspeptic complaints which is largely due to a placebo effect. Our data once again question the clinical significance of gastritis in relation to dyspeptic complaints and also cast doubt on the clinical relevance of therapeutic measures aimed at eradication of Campylobacter pylori. 
1 Dowges JL. Spirochetes in gastric glands of Macacus rhesus and humans without definite history of related disease. Proc Soc Exp Eiol Med 1938;38:536-8.

2 Freedburg AS, Barron LE. The presence of spirochetes in human gastric mucosa. Am I Dig Dis $1940 ; 17: 443-5$.

3 Steer HW, Collin-Jones DG. Mucosal changes in gastric ulceration and their responsie to carbenoxalone sodium. Gut $2975 ; 16: 594-7$.

4 Marsha11 BJ, Warren JR. Undelentified curved bacilli in the stomach of patients with gastritis and peptic ulceration. Lancet $1984 ; I ; 1311-14$.

5 Jones DM, Lessells AM, Eldridge J. Campylobacter-like organisms on the gastric mucosa: culture, histological and serological studies. J Clin Pathol 1984;37:1002-6.

6. Axon ATR. Campylobacter pyloridis, what role in gastritis and peptic ulcer? Bric Med J 1986;293:772-3.

7 Rathbone BJ, Wyatt JI, Heatley RV. Campylobacter pyloridis: a new factor in peptic ulcer disease. Gut $1986 ; 27: 6.35-41$.

8. Loffeld RJLF, Potters HVPJ, Arends JW, Stobberingh E, Flendrig JA, van Spreeuwel JP. Campylobacter assaciated gastritis in patients with non-ulcer dyspepsia. J Clin Pathol $1988 ; 41: 84-8$.

9 Anonymus. Non-ulcer dyspepsia (editorial). Lancet 4986;i:1306-7.

10 Borody T, Daskaloupoulos G, Brand1 S, Garrick J, Hazell S. Dyspeptic symptoms improve following eradication of gastric Campylobacter pyloridis. Gastroenterology 1987;92: abstract 1324 .

11 Anderson LP, Rothgart NP, Andreasen JJ, Kromann H. Treatment of Campylobacter pyloridis in vitro and in vivo. Proceedings of the 4th International Workshop on Campylobacter infections Kopenhagen 1987. In Press.

12 Czinn S, Can H, Aronoff S. Susceptibility of Campylobacter pyloridis to three macrolide antibiotics (erythromycin, roxathromycin[RU 28961] and $\mathrm{CP}$ 62993) and rifampicin. Antimicrobial Agents and Chemotherapy 1986;30:328-9.

13 Goodwin CS, Blake P, Blincow B. The minimum inhibitory and bactericidal concentrations of antibiotics and anti-ulcer agents against Campylobacter pyloridis. J of Antimicrobial Chemothexapy $1986 ; 17: 309-14$.

14 Lambert JR, Hansky J, Davidson $\mathbf{A}$, Pinkard $\mathbf{K}$, Stockman $K_{\text {. }}$ Campylobacter-ilke organisms (CLO) in wivo and vitro susceptibility to antimicrobial and anti-ulcer therapy. Gastroenterology $1986 ; 88: 1462$.

15 MeNulty CAM, Dent J, Wise R. Susceptibility of clinical isolates of Campylobacter pyloridis to 11 antimicrobial agents. Campylobacter III AD Pearson, MB Skirrow, H Lior, B Rowe ed. Public Health Laboratory Service London 1985.

16 Arena JN, Drew RH. Poisoning 5e Edition 1986 Chapter 7 CC Thomas publisher Springfield Illinois USA.

17 Witehead $\mathbf{R}$. Mucosal biopsies of the gastrointestinal tract in: JL Bennington ed. Major problems in pathology Vol III 2 nd ed Phtladelphia: WS Saunders 1979:15.

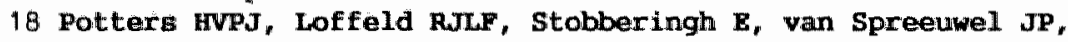
Arends JW. Rapid staining of Campylobacter pyloridis. Histopathology $1987 ; 11: 1223$. 
19 Lambert JR, Borromeo M, Korman MC, Hansky J, Eaves ER. Effect of colloidal bismuth (De-Nol) on healing and relapse of duodenal ulcers: role of Campylobacter pyloridis. Gastroenterology $1987 ; 92$ : abstract 209.

20 Rokkas T, Pursey C, Simmons NA, Filipe MI, Sladen GE. Non - ulcer dyspepsia and colloidal bismuth subcitrate therapy, the role of Campylobacter pyloridis. Gastroenterology $1987 ; 92$ : abstract 213 .

21 Hislop $I$, Glancy $\mathbb{R}$, Armstrong $J$. Histological improvement of active chronic gastritis in patients treated with De-Nol. Austr and New Zealand $J$ Med $1984 ; 14: 907$.

22 Lambert JR, Dunn KI, Turner $H_{\text {, Korman }}$,C. Effect on histological gastritis following eradication of Campylobacter pyloridis. Gastroenterology 1986;90:1509.

23 Borrody $T$, Hennessy $W$, Daskaloupoulos G, Carrick J, Hazell S. Double blind trial of De-Nol in non-ulcer dyspepsia associated with Campylobacter pyloridis gastritis. Gastroenterology $1987 ; 92$ :abstract 919 .

24 Lambert JR, Borromeo M, Korman MC, Hansky J. Role of Campylobacter pyloridis in non-ulcer dyspepsia: a randomised controlled trial. Gastroenterology 1987;92:abstract 918 .

25 Rauws EAJ, Langenberg $w$, Houthof $H J$, Zanen HC, Tytgat GNJ. Campylobacter pyloridis associated chronic active gastritis. Gastroenterology $1988 ; 94: 33-40$.

26 Langenberg ML, Rauwsi EAJ, Schipper MEI, Widjojokosmo A, Tytgat GNJ, Rietra PJGM, zanen HC. The pathogenetic rolle of Campylobacter pyloridis studied by attempts to eliminate these organisms. In: Campylobacter III, Proceedings of the 3 th International workshop on Campylobacter Infections $\mathrm{Ed}$ : $\mathrm{AB}$ Pearson, MB Skirrow, H Lior, B Rowe public Health Laboratory Service London 1985.

27 Slomiany BL, Bilski J, Munty UL et al. Campylobacter pyloridis degrades mucin and undermines gastric mucosal integrity. Gastroenterology $1987 ; 92: 1645$.

28 McNulty CAM, Geanty JC, Crump $B$ et al. Campylobacter pyloridis and associated gastrits: investigator blind placebo controlled trial of bismuth salicylate and erythromycin ethylsuccinate. BI Med J 1986;293:645-9.

29 Langenberg $\omega$, Rauws EAJ, Houthoff HJ, Oudbier J, Tytgat GNJ, zanen HC. Follow-up of Campylobacter pyloridis associated gastritis (CPG) after treatment with amoxycilin and/or colloidal bismuth subcitrate. Proceedings of the 4 th International workshop on Campylobacter Infections Kopenhagen 1987 In Press.

30 Hui WM, Lam SK, Chau PY et al. Persistence of Campylobacter pyloridis despite healing of duodenal ulcer and improvement of accompanying duodenitis and gastritis. Dig Dis Sci $1987 ; 32: 1255-60$.

31 Borody T, Carrick J, Hazell SL. Symptoms improve after the eradication of gastric Campylobacter pyloridis. Med J Austr $1987 ; 146: 450-1$.

32 Rreuning J, Bosman FT, Kuiper G, WaI AM, Lindeman J. Gastric and duodenal mucosa in healthy individuals. J Clin Pathol $1978 ; 31: 69-77$. 



\section{EPILOGUE}

Non-ulcer dyspepsia is a clinically defined syndrome with a high prevalence in general practice. Internists or gastroenterologists are often faced with patients suffering from this condition. Despite several therapeutic approaches complete relief of complaints is almost never obtained.

Non-ulcer dyspepsia is known to be often associated with signs of gastritis, but on the other hand the presence of gastritis is not always accompanied by dyspeptic complaints. Therefore, the exact relation between non-ulcer dyspepsia and gastritis remained obscure.

The emergence of Campylobacter pylori as a possible causative agent in gastritis has led to the expectation that now the condition non-ulcer dyspepsia could be reduced to a "simple" problem with a "simple" solution.

As to be expected, however, the initial enthusiasm has rapidly cooled down. Several questions should be positively answered before such thinking would become realistic. First: Is Campylobacter pylori a causative and a sole factor leading to gastritis?

Second: Is there a correlation between Campylobacter associated gastritis and non-ulcer dyspepsia?

Finally: Will antibacterial medication cure Campylobacter associated gastritis as well as non-ulcer dyspepsia?

In regard of the first question there are clinical, epidemiological and experimental data available in the literature incriminating Campylobacter pylori as a causative agent in gastritis. The intervention study presented in chapter 8 , demonstrating that therapy aimed at attacking the microorganism decreases Campylobacter pylori colonization and signs of gastritis, also supports a causative role of the bacillus. 
However, in chapter 7 we found evidence that in certain situations there may be other causes of gastritis, most notably bile reflux.

In connection with the second question, chapter 3 provides data which show that Campylobacter associated gastritis is present in more than half of the patients with non-ulcer dyspepsia. This implies that a substantial number of patients with nonulcer dyspepsia does not have evidence of Campylobacter associated gastritis.

The results shown in chapter 6 may suggest that "healthy" indiduals may suffer or have suffered from Campylobacter associated gastritis in about one third of cases. It should be realised, however that the presence of antibodies against campylobacter Pylord in these persons was inferred from a positive ELISA and that we were not informed whether the individuals participating in this study were free of complaints. The data indicate that the chance that a Campylobacter assoclated gastritis is present in patients with non-ulcer dyspepsia is twice as high as compared to "healthy" individuals.

Regarding the final question our therapeutical intervention study presented in chapter 8, clearly indicated that antibacterial treatment reduces or cures campylobacter associated gastritis. However, at the end of the study a significant difference in dyspeptic complaints between patients treated with colloidal bismuth subcitrate or placebo was not demonstrated. Improvement of complaints occurred in a large number of cases after colloidal bismuth subcitrate or placebo treatment. Nausea and meteorism, however, appeared to be more ameliorated in the patients treated with colloidal bismuth subcitrate.

From the sum of the above data it may be concluded that there are indications that Campylobacter pylori and type $B$ gastritis are rather strongly but not unequivocally related and that Campylobacter associated gastritis and non-ulcer dyspepsia are somehow related but not in a "simple" way.

Agalnst the background of the observations reported in chapter 3 we developed the hypothesis that there is a balance between local as well as systemic mucosal defence mechanisms on 
the one hand and virulence as well as quantity of Campylobacter pylori on the other hand, whilch when distorted may lead to gastritis, whether or not accompanied by symptoms. Recovery of the balance results in decrease of Campylobacter pylori colonization, improvement of gastritis, and possibly complaints. This hypothesis is compatible with the clinical picture characterised by waxing and waning of symptoms in patients with non-ulcer dyspepsia.

The fact that all patients studied in this thesis had nonulcer dyspepsia implies that spontaneous remission due to recovery of the balance is possible without direct effect on upper abdominal complaints.

Supported by data from the literature, we think that there are more pathogenetic factors playing a role in the development of gastritis, like hot foods, spices, alcohol, bile reflux, and nicotine. Campylobacter pylori, however, probably is the most important stimulus leading to gastritis.

We, therefore, reason that campylobactex pylori can change from a causative to a commensal role and generally becomes active (causative) in concert with other impeti, such as alcohol, nicotine or spices, undermining local mucosal integrity. In this context it may be better to speak of "Campylobacter dominated gastritis" rather than to use the designation "Campylobacter associated gastritis".

At this moment the relation between non-ulcer dyspepsia and Campylobacter associated gastritis is still unclear. We feel that this obscure relation, at least partly, may be due to the rather vague definition of non-ulcer dyspepsia and/or incompleteness of questionnaires used for the assessment of dyspeptic complaints.

Our finding that nausea and meteorism are affected by anti. Campylobacter pylori therapy supports our hypothesis that it should be possible to distinct particular and perhaps specific patterns of dyspeptic complaints showing a more clear relation to Campylobacter associated gastritis.

Future research on Campylobacter pylori and non-ulcer dyspepsia should be directed to the identification of the 
patients in which the contribution of Campylobacter pylori in gastritis and ayspeptic complaints is significant, in order to identify those patients with non-ulcer dyspepsia who might benefit from anti Campylobacter pylori treatment. Studies using computerized questionnalres inquiring specifically at all symptoms of the dyspeptic syndrome including duration and severity of complaints in relation to histological and/or serological investigations in dyspeptic patients as well as "healthy" Individuals are necessary. To this end the sensitive immunohistochemical method described in chapter 4 and more so the ELISA procedure reported in chapter 5 may be useful.

The best therapy at present probably is colloidal bismuth subcitrate. However, so far most intervention studies demonstrated recrudescence of Campylobacter associated gastritis after cessation of anti Campylobacter pylori treatment. This implies that more effective strategies for eradication of Campylobacter pylorl should be developed. Combination therapy with amoxycillin and/or metronidazole possibly is more effective. Controlled studies on this subject, however, are not yet present and currently in progress.

Given the uncertain relationship between Campylobacter pylori and dyspeptic complaints, at present, large scale therapeutical intervention seems not yet justified. However, patients with longstanding recurrent complaints should be given the benefit of the doubt and treated with effective anti Campylobacter pylori treatment like colloidal bismuth subcitrate. 
Upper abdominal complaints frequently occur and are widespread. In about two third of the patients an anatomical or radiological diagnosis can be made after invasive and/or noninvasive investigations. The remainder of the patients by definition suffer from so-called non-ulcer dyspepsia.

Non-ulcer dyspepsia probably is not a single entity and is accompanied by a vague clinical syndrome, for which no effective therapy is available. Suspected underlying conditions for the syndrome are histologically confirmed gastritis and motility disorders.

Gastritis, however, can be found in symptomatic as well as asymptomatic individuals. In several studies asymptomatic gastritis was found with increasing age. Therefore, many authors regarded gastritis as an aging phenomenon of the stomach without clinical significance.

In 1984 a revival in the interest for gastritis and hence also for non-ulcer dyspepsia arose due to the description of Campylobacter pylori, a Gram negative microorganism which subsequently appeared to be closely associated with a special type of gastritis. As a result it was thought that patients with non-ulcer dyspepsia might suffer from Campylobacter associated gastritis and might benefit from antibacterial therapy.

In this thesis several studies are presented on the relation of Campylobacter associated gastritis and non-ulcer dyspepsia, the scope and outline of which are described in chapter 1 .

Chapter 2 provides a review of the literature on dyspepsia, Campylobacter pylori, and gastritis. Three different types of gastritis are presently discriminated. The most prevalent is type B (antral) gastritis, which appeared to be strongly associated with Campylobacter pylori. In different sections of this chapter the microbiological, morphological, and histological characteristics of this bacterium are described. In the final paragraph the hypotheses currently proposed concerning possible 
pathophysiological mechanisms of the bacterium in the causation of gastritis are outined.

In the study of Campylobacter associated gastritis it is of crucial importance to develop sensitive and reliable detection methods. In chapter 3 it is demonstrated that the modified Giemsa stain is more sensitive for the detection of Campylobacter pylori in histological sections than the silver stain according to Warthin and starry, which so far has been most frequently employed. Chapter 4 further elaborates detection methods and compares the modified Giemsa stain, an immunoperoxidase stain using a polyclonal antiserum against Campylobacter pylori and microbiological culture of the microorganism. The immunoperoxidase sitain appeared to show the highest diagnostic yield. Our data indicate that culture is specific but lacks sensitivity. This poor sensitivity can be explained by the correlation between culture results and bacterial load in the gastric biopsy specimens. Negative cultures more frequently occurred in cases with low bacterial load. Therefore especially in cases in which biopsies are performed during follow-up after therapeutical intervention, whereby bacterial load is presumably decreased as a result of therapy, it is of crucial interest to apply the most sensitive detection method to differentiate between eradication and suppression of Campylobacter pylori. To this effect the modified Giemsa stain but even more so the immunoperoxidase method have proven to be of great use.

In chapter 3 the results of a study on the prevalence of Campylobacter associated gastritis in patients with non-ulcer dyspepsia are reported. Over 50\% of the studied patients appeared to show signs of Campylobacter associated gastritis, Campylobacter pylori frequently being detectable in high numbers. When normal gastric mucosa was found $43 \%$ of the cases appeared to show Campylobacter pylori in low numbers. From these results we concluded that the relation between Campylobacter pylori and gastritis is not qualitative, as generally assumed, but rather quantitative. This conclusion led us to the hypothesis that a balance exists between local mucosal defense mechanisms on the one hand and bacterial virulence and load on the other hand, which, when distorted would lead to overt gastritis possibly with 
dyspeptic complaints. However, no difference in clinical piresentation between patients with or without campylobacter pylori infection could be demonstrated.

The systemic antibody response directed to Campylobacter pylori could be used to diagnose Campylobacter associated gastritis. Chapter 5 explores the feasibility of this option using an ELISA procedure to detect anti Campylobacter pylori antibodies. The results of this ELISA appeared to show a correlation with the presence or absence of Campylobacter associated gastritis and demonstrated extremely high positive and negative predictive values. It would appear possible to diagnose Campylobacter associated gastritis solely by determining this antibody titre. A decision scheme is, therefore, proposed which potentially could lead to a more efficient use of upper gastrointestinal endoscopy omitting gastroscopy in a considerable number of cases. Before this proposed working method can be generally employed, however, more data should be available on the prevalence and significance of campylobacter associated gastritis in conditions other than peptic ulcer disease and gastritis. In addition the question concerning the necessity of treatment of campylobacter assaciated gastritis should be properly addressed.

Detection of antibodies is useful for epidemiological studies. Such a study is presented in chapter 6 in which the prevalence of antibodies in two different groups of individuals is studied. "Healthy" blood donors were compared with patients visiting the outpatient clinics or admitted in hospital not because of dyspeptic complaints. The number of positive sera was significantly higher in patients as compared to "healthy" blood donors. This supports the hypothesis presented in chapter 3 . We assume that the balance between defense mechanisms and virulence of Campylobacter pylori is more often distorted in patients as a result of their underlying disease. In addition an increasing occurrence of antibodies against Campylobacter pylori with rising age was demonstrated.

In chapter 7 the results of a retrospective study on the prevalence of Campylobacter associated gastritis in the partially resected stomach are presented. Because Campylobacter associated gastritis is strongly correlated with peptic ulcer disease it is 
of interest to study the role of Campylobacter pylori in this condition by evaluating the fate of the microorganism after installment of effective anti-ulcer therapy. The data indicate that gastritis in the gastric remnant still is associated with Campy lobacter pylori while after removing the antrum the microorganism is eradicated at the stomal site in half of the cases. The gastritis at this site persists, probably due to reflux of blle which has bactericidal properties and induces gastritis. It is concluded that Campylobacter pylori only has an additional role in the pathogenesis of peptic ulcer disease and that there are more factors in the pathogenesis of gastritis, like bile reflux. The question as to whether patients with Campylobacter assoclated gastritis and non-ulcer dyspepsia benefit from anti Campylobacter pylori therapy is addressed in chapter 8 . The results of a randomised placebo controlled therapeutic intervention study with colloidal bismuth subcitrate are presented. After a 28 days course of colloidal bismuth subcitrate a marked decrease in Campylobacter pylori colonization was observed with an improvement of gastritis score. This suggests a pathogenetic relation between Campylobacter pylori and gastritis. Placebo therapy did not show any effect, nelther on the histological picture nor on the colonization grade of Campylobacter pylori. Eradication of Campylobacter pylori with this therapy only occurred in a small number of patients. Improvement of complaints occurred in a large number of patients from the group treated with colloidal bismuth subcitrate as well as from the group treated with placebo. However, the improvement of nausea and meteorism were better in the treatment group. It is concluded that campylobacter associated gastritis improves after treatment with colloidal bismuth subcitrate. The clinical effect, however, largely appeared to be due to a placebo effect.

The final chapter provides an epilogue on the subject. Supported by data from the literature it is argued that gastritis is the result of several impeti acting in concert with each other. Among these are hot foods, spices, alcohol and Campylobacter pylori, which probably is the most important impetus. The relation of Campylobacter associated gastritis and non-ulcer dyspepsia is not clear due to the vague definition of the 
syndrome and incompleteness of the questionnalres used for the assessment of complaints. Although the clinical significance of Campylobacter associated gastritis is not yet fully appreciated, the condition has a meaning in patients with non-ulcer dyspepsia since in these patients the prevalence of Campylobacter associated gastritis is considerably higher as compared to "healthy" individuals. Future research should be directed to the identification of those patients with non-ulcer dyspepsia and campylobacter associated gastritis in whom the contribution of campylobacter pylori is significant and who might benefit from anti. Campylobacter pylori therapy. Histological and serological studies in patients with non-ulcer dyspepsia and healthy individuals, using computerized questionnaires including all possible dyspeptic complaints with duration and severity " are necessary to definitely answer the question concerning the clinical relevance of the infection and the necessity of treatment of Campylobacter associated gastritis. 
Dyspeptische klachten komen frequent roor. Bij ongeveer tweederde deel van de patiënten kan na invasief en/of noninvasief onderzoek een macroscopische of röntgenollogische diagnose gesteld worden. Bij de overige patienten is er, per definitie, sprake van een non-ulcer dyspepsie.

Non-ulcer dyspepsie is vermoedelijk multifactorieel en gat gepaard met een vaag klinisch syndroom. Effectieve behandeling is in het algemeen niet mogelijk. Histologisch aangetoonde gastritis en/of motiliteitsstoringen zijn mogelijke oorzaken van non-ulcer dyspepsie.

Gastritis komt voor bij patiënten met dyspeptische klachten maar ook bij asymptomatische "gezonde" individuen, met name ouderen. In diverse studies werd geen samenhang gevonden tussen de aanwezigheid van dyspeptische klachten en gastritis. Gastritis werd dan ook door vele auteurs beschouwd als een verouderings verschijnsel van de maag zonder enige klinische betekenis.

In 1984 herleefde de belangstelling voor gastritis, en daarmee ook voor non-ulcer dyspepsie, door de beschrijving van een Gram negatief microorganisme, Campylobacter pylori, dat zeer nauw samenhangt met type B (antrum) gastritis. De correlatie van Campylobacter pylori met gastritis is zo groot dat een oorzakelijke rol voor de hand ligt. Campylobacter gastritis kan een behandelings perspectief bieden voor patiënten met non-ulcer dyspepsie.

In dit proefschrift worden een aantal studies gepresenteerd over de relatie van Campylobacter gastritis met non-ulcex dyspepsie, waarvan de onderlinge samenhang in hoofdstuk 1 is aangegeven.

In hoofdstuk 2 wordt een literatuur overzicht met betrekking tot dyspepsie, gastritis en Campylobacter pylori gepresenteerd. Gastritis wordt onderverdeeld in drie types, warvan de type $B$ (antrum) gastritis het meeste voorkomt. De antrum gastritis hangt 
naw samen wet de anwezigheid wan Campylobacter pylori. De microbiologische, mox fologische en histologische kenmerken van het micromorganisme worden beschreven. In de latste paragraf van dit hoofdstuk worden de mogelijke pathofysiologische mechanismen, volgens welke Campylobacter pylori gastritis kan veroorzaken, geschetst.

Goede en betrouwbare diagnostiek is noodzakelijk. In hoofdstuk 3 wordt aangetoond dat de gemodificeerde Giemsa kleuring sensitlever is voor het aantonen van Campylobacter pylori in histologische preparaten dan de, in de literatuur vaak gebruikte, zilver kleuring volgens warthin en starry. In hoofdstuk 4 wordt verder ingegaan op de histologische diagnostiek en worden de gemodiflceerde Glemsa kleuring, een immunoperoxidase kleuring met een polyclonal antiserum tegen Campylobacter pylori en de kweek vergeleken. De immunoperoxidase kleuring blijkt de hoogste alagnostische opbrengst te hebben. De kweek is weliswaar zeer specifiek maar slechts weinig sensitief. Deze lage sensitiviteit wordt verklaard door de correlatie van de kweekresultaten met de hoeveelheid aanwezige micro-organismen in het antrum biopt. Negatieve kweken komen significant vaker voor in die gevallen waarbij sprake was van een lage kolonisatiegraad van Campylobacter pylori. Vooral in die gevallen waarbij biopten genomen worden in het kader van follow-up na therapeutische interventie, waarbij aangenomen kan worden dat de kolonisatiegraad van Campylobacter pylori afneemt als gevolg van de behandeling, is het van belang om de meest sensitieve diagnostische methode te gebruiken. Adequate diagnostiek is van belang om te differentiëren tussen eradicatie en suppressie van Campylobacter pylori. De gemodificeerde Giemsa kleuring en de immunoperoxidase kleuring hebben hun bruikbaarheid in dit verband bewezen.

In hoofdstuk 3 worden de resultaten beschreven van het voorkomen van Campylobacter gastritis bij patiënten met non-ulcer dyspepsile. Ruim 55\% van de patiënten blijkt een Campylobacter gastritis te hebben. In $43 \%$ van de gevallen met normale antrum mucosa wordt bij histologisch onderzoek Campylobacter pylori gevonden, echter in lage kolonisatiegraad. Bij gastritis is de kolonisatie graad in het merendeel van de gevallen veel hoger. De samenhang van campylobacter pylori met gastritis is niet 
kwalitatief, zoals aanvankelijk verondersteld werd in de Miteratuur, mar kwantitatief. In dit onderzoek wordt geen verschil gevonden in klinische presentatie tussen patienten met of zonder gastritis of patiënten met of zonder Campylobacter pylori. De aanwezigheid van de kwantitatieve samenhang van Campylobacter pylori met gastritis heeft tot de volgende hypothese geleid* er bestaat een balans tussen mucosa afweer enerzijds en virulentie en aantal bacteriën anderzijds. Wanneer deze balans verstoord wordt, kan dit leiden tot toename van het aantal microorganismen met het ontstaan van een gastritis.

De bepaling van IgG antilichamen gericht tegen Campylobacter pylori is zinvol in de diagnostiek van Campylobacter gastritis. In hoofdstuk 5 worden de resultaten gepresenteerd van een studie die gebruik maakt van een ELISA techniek. De hoogte van de gemeten exinctie warde correleert goed met de aanwezigheid of afwezigheid van een Campylobacter gastritis. De ELISA die gebruikt wordt heeft een hoge positieve en negatieve voorspellende waarde. Hieruit volgt dat de antilichaam respons is te gebruiken als een screening op de aanwezigheid van Campylobacter gastritis. Er wordt een beslisboom gepresenteerd die zou kunnen leiden tot een efficienter gebruik van de gastroscopie. Echter voordat deze beslisboom toegepast kan worden moeten meer gegevens bekend $\mathrm{zijn}$ over het voorkomen en de relevantie van Campylobacter gastritis bij andere aandoeningen dan gastritis en het peptisch ulcus lijden. Bovendien moet de vraag of een Campylobacter gastritis behandeling behoeft definitief beantwoord worden.

De bepaling van antilichamen is bruikbaar voor epidemiologisch onderzoek. In hoofdstuk 6 wordt een studie gepresenteerd over het voorkomen van antistoffen bij twee verschillende populatiegroepen. "Gezonde" donoren worden vergeleken met patiënten die de polikliniek bezochten of opgenomen waren en die niet onderzocht werden in verband met dyspeptische klachten. Het blijkt dat antilichamen en dus gastritis significant vaker voorkwamen bij patiënten. De verklaring hiervoor is mogelijk de in hoofdstuk 3 beschreven hypothese. Het is aannemelijk dat de balans tussen afweer en virulentie bij patiënten vaker verstoord is als gevolg van een onderliggende ziekte. De prevalentie in het voorkomen van antistoffen stijgt met de leeftijd. 
Hoofdstuk 7 beschrijft een retrospectief onderzoek naar het voorkomen van Campylobactex gastritis in de resectie maag. Omdat Campylobacter gastriti ook naww samenhangt met het peptisch ulcus lijden is het mogelijk om de rol van campylobacter pylori bij het peptisch ulcus lijden te onderzoeken door te evalueren wat ex gebeurt met het micro-organisme na effectieve anti-ulcer behandeling. Uit de resultaten blijkt dat gastritis in de "restmaag" geassocieerd blijft met de aanwezigheid van Campylobacter pylor1. Echter slechts in de helft van de gevallen van anastomose gastritis is het micro-organisme aanwezig. Dit kan verklaard worden door gallige reflux, die enerzijds bactericide is en anderzijas een gastritis induceert. Geconcludeerd wordt dat Campylobacter pylori na maagresectie aanwezig blijft, dat de gastritis in de restmaag geassocieerd blijft met het microorganisme en dat de bacterie slechts een additionele rol speelt In de genese van het peptische ulcus lijden. Bovendien spelen meer factoren een rol in de genese van gastritis, ondex anderen gallige reflux.

De vraag of patiënten met non-ulcer dyspepsie en Campylobacter gastritis baat hebben bij een anti Campylobacter pylori behandeling wordt benaderd in hoofdstuk 8 . De resultaten van een dubbelblinde placebo gecontroleerde trial met colloidaal bismuth subcitraat worden gepresenteerd. Na een 28 daagse behandeling treed een significante daling op van de kolonisatie graad van Campylobacter pylori die gepaard gaat met een significante verbetering van het histologisch beeld. Dit suggereert een pathogenetische relatie van Campylobacter pylori met gastritis. In de placebo groep treden geen veranderingen op ten opzichte van de uitgangssituatie. Volledig verdwijnen van Campylobacter pylori treedt slechts in een klein aantal gevallen op. De klachten namen af, zowel bij de patiënten die met colloidaal bismuth behandeld werden, als bij de patiënten die de placebo kregen. Echter misselijkheid en het opgeblazen gevoel nemen duidelijker af in de met colloidaal bismuth behandelde groep. Geconcludeerd wordt dat de gastritis verbetert na behandeling met colloidaal bismuth subcitraat. Het klinisch effect blijkt echter goeddeels een placebo effect. 
Het laatste hoofdstuk geeft een beschouwing over de relevantie van Campylobacter gastritis bij patienten met nonulcer dyspepsie. Gastritis wordt door ons beschouwd als het gevolg van verschillende noxen, zoals alcohol, kxuiden, roken en Campylobacter pylori, die warschijnlijk de belangrijkste noxe is. De relatie tussen Campylobacter gastritis en non-ulcer dyspepsie is nog niet geheel opgehelderd, mede door de "vaagheld" van het syndroom en de onvolledige vragenlijsten die gebruikt werden voor de klinische evaluatie. Dat er echter een relatie is moge blijken uit onze bevinding dat de prevalentie van campylobacter gastritis bij patiënten met non-ulcer dyspepsie hoger is dan bij "gezonden".

Toekomstig onderzoek moet erop gericht zijn om die patiënten met non-ulcer dyspepsie en campylobacter gastritis te identificeren bij wie Campylobacter pylori de grootste rol speelt en die dus baat kunnen hebben bij anti campylobacter pylori therapie. Routinematig histologisch en serologisch onderzoek bij patiënten met non-ulcer dyspepsie en bij "gezonden", waarbij gebruik gemaakt wordt van uitvoerige computer gestuurde vragenlijsten, is nodig om de relatie van non-ulcer dyspepsie met Campylobacter gastritis en de noodzaak tot behandeling definitief vast te stelien. 
Alhoewel het leeuwedeel van het werk aan een proefschrift voor rekening van de promovendus komt, kan hij dit niet tot een goed einde brengen zonder hulp, steun en inzet van anderen. Derhalve wil ik graag iedereen bedanken die aan de totstandkoming van dit proefschrift heeft bijgedragen.

Prof Dr JA Flendrig, aan U een bijzonder woord van dank niet alleen omdat $U \mathrm{mij}$ in opleiding nam tot internist, maar ook omdat $\mathrm{U}$ een goed klimat geschapen heeft voor het doen van wetenschappelijk onderzoek.

Dr J van Spreeuwel, beste Jan, jij had het idee om eens te gaan kijken naar die "vreemde beestjes" in de maag. Met genoegen denk ik terug aan de uren die wij, al filosoferend over gastritis en non-ulcer dyspepsie hebben doorgebracht. Dat deze overpeinzingen niet zonder resultaat zijn gebleven moge blifken uit dit boekje.

Prof $D r$ JW Arends, beste Jan-Willem, jouw hulp en inzet zijn voor mij van essentieel belang geweest. Jij was het die mij leerde hoe ik een wetenschappelijk artikel moest schrijven. De correcties in de tekst en de inhoudelijke bijdragen waren stimulerend en zeer leerzaam. Voor jouw kritische en gedegen begeleiding wil ik je van harte bedanken.

Dr E Stobberingh, beste Ellen, de samenwerking met de afdeling microbiologie was een war genoegen en ik hoop dat deze samenwerking in dezelfde harmonie voortgezet kan worden. zonder een goede laboratorium ondersteuning is geen onderzoek mogelijk. Monique Wunderink zorgde voor de uitvoering van de kweken, de ELISA en de immunoperoxidase techniek.

Drs $V$ Potters, beste Vincent, we hebben vele uurtjes samen achter de microscoop doorgebracht. Je hebt mij veel over histologie geleerd, waardoor ik later in staat was om vele coupes zelfstandig te beoordelen.

Drs B Loffeld, beste Boudewijn, jouw wil ik bedanken voor de 
vele hand- en spandiensten. Ons gecombineerd werk heeft zijn vruchten afgedragen.

De dames van de endoscople afdeling, Marja de Greeve, Anita Nelissen, Monique Bisschops, Lucie Jongen, Daisy Brants, Tineke Zandstra en $\mathbb{L}$ iesbeth Theunissen wil ik bedanken voor de hulp die zij gegeven hebben en voor de vele kopjes koffie.

De secretaresses van de afdeling pathologie waren altijd bereld om "illegal" de computer te raadplegen waardoor ik uitslagen veel sneller in mijn bezit kreeg. Zonder deze bereidwiligheid was het nooit mogelijk geweest om de trial in zo een kort tijdsbestek af te ronden.

De secretaresses van de afdeling interne geneeskunde, in het bijzonder Desirée van Schoubroeck, Anke Hendriks, Wilke Ellenbroek en Tiny Wouters leerden mij omgaan met de computer en de tekstverwerker. Bedankt voor de tips en het geduld dat jullie haddien.

De leden van de beoordelingscommissie wil ik bedanken voor hun kritische beoordeling van het manuscript.

De firma Gist-Brocades leverde de medicatie en zorgde voor financiele ondersteuning.

op de laatste, maar belangrijkste plaats wil ik Marjo bedanken voor al haar steun en liefde. zonder haar was mijn medische studie niet zo voorspoedig geweest. 
Geboren 21 november 1953 te Heerlen.

1966-1972 Atheneum B, St. Bernardinus college te Heerlen.

1972-1974 Opleiding voor laboratorium personeel OLAN te Nijmegen.

1974-1975 Militaire dienst 103 Geneeskundig Bataljon.

1976 Werkzaam als medisch analist: laboratorium voor hematologie en stollingsonderzoek, de Wever ziekenhuis Heerlen (hoofd destijas Dr. JP van der Plas).

1976 Start Medische studie Rijksuniversiteit Maastricht.

1982 Behalen arts-diploma.

1982-1983 Werkzaam als arts-assistent afdeling interne geneeskunde, st. Laurentius ziekenhuis Roermond.

1984-1985 Werkzaam als arts-assistent afdeling interne geneeskunde en cardiologie. St. Jozef ziekenhuis Kerkrade (hoofd destijds drs. J Scherpbier).

1985 Werkzaam als assistent geneeskundige niet in opleiding, afdeling interne geneeskunde Academisch ziekenhuis Maastricht.

1986 start opleiding tot internist Academisch ziekenhuis Maastricht (opleider Prof. Dr. JA Flendrig).

De studies die geleid hebben tot dit proefschrift zijn uitgevoerd op de afdelingen Interne Geneeskunde en Pathologische Anatomie van het Academisch ziekenhuis Maastricht en de afdeling Medische Microbiologie van het Biomedisch Centrum van de Rijksuniversiteit Limburg. 